\title{
The Effect of the Process Approach on Students' Writing Success: A Meta-Analysis
}

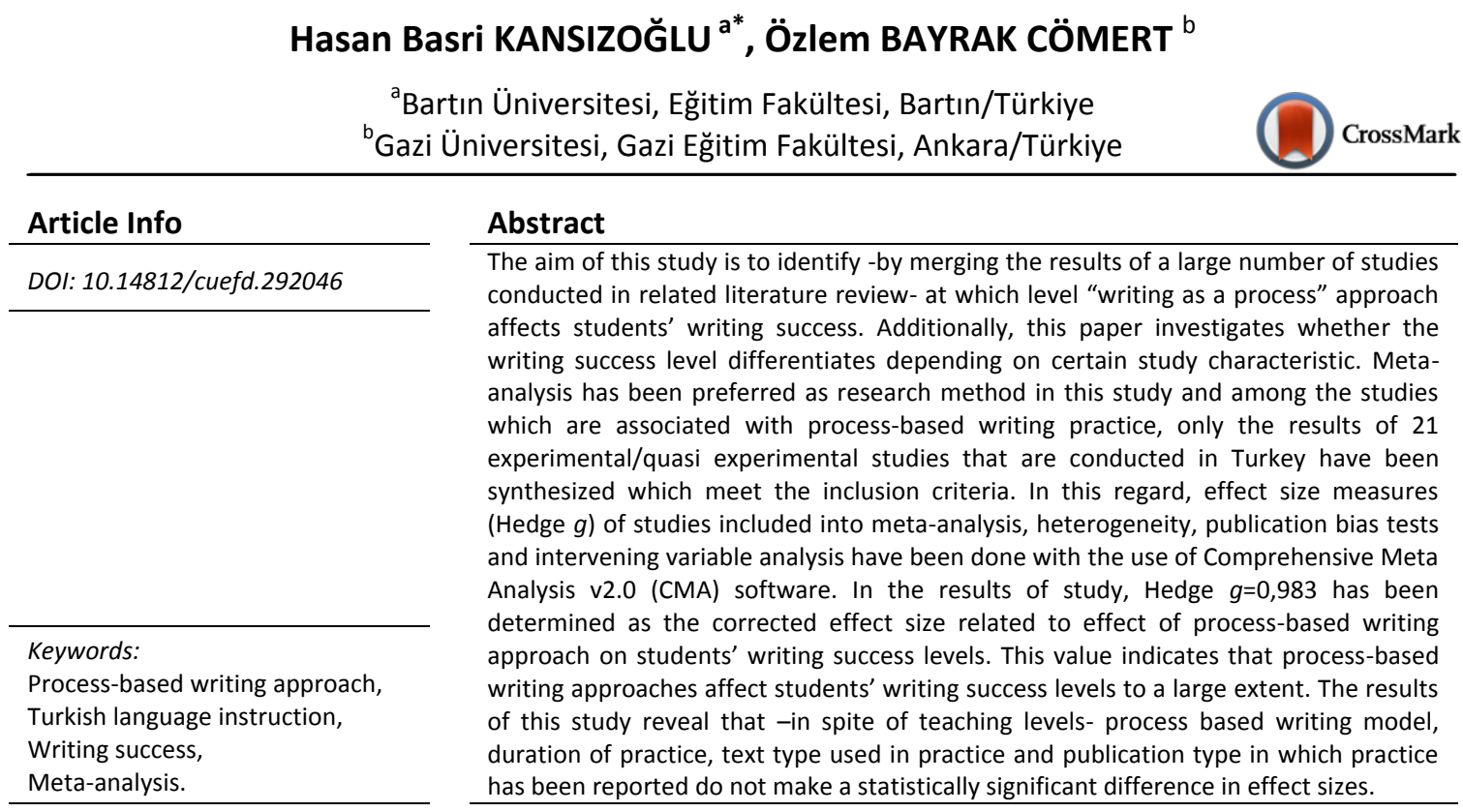

\section{Süreç Odaklı Yazma Yaklaşımlarının Yazma Başarısına Etkisi: Bir Meta Analiz}

Makale Bilgisi
DOI: $10.14812 /$ cuefd.292046

Anahtar Kelimeler:

Süreç odaklı yazma yaklaşımı, Türkçe öğretimi,

Yazma başarısı,

Meta analiz.

\begin{abstract}
Öz
Bu araştırmanın amacı, alan yazında yapılmış çalışmalardan elde edilen sonuçların birleştirilmesi yoluyla süreç odaklı yazma yaklaşımlarının öğrencilerin yazma başarı düzeylerini ne düzeyde etkilediğini belirlemektir. Bunun yanında söz konusu başarı düzeyinin belli çalışma karakteristiklerine göre farklılaşıp farklılaşmadığını tespit etmektir. Meta analiz yönteminin kullanıldığı araştırmada, Türkiye'de süreç odaklı yazma uygulaması kapsamında değerlendirilebilecek çalışmalardan uygunluk ölçütlerini karşılayan 21 deneysel/yarı deneysel çalışma sonucu sentezlenmiştir. Bu kapsamda meta analize dâhil edilen çalışmaların etki büyüklük değeri (Hedge $g$ ) hesaplamaları, heterojenlik ve yayın yanlılığı testleri ile ara değişken analizleri Comprehensive Meta Analysis v2.0 (CMA) istatistik programı kullanılarak yapılmıştır. Araştırmanın sonucunda süreç odaklı yazma yaklaşımlarının öğrencilerin yazma başarı düzeyleri üzerindeki düzeltilmiş etki büyüklüğü $g=0.983$ olarak belirlenmiştir. Bu değer, süreç odaklı yazma yaklaşımlarının öğrencilerin yazma başarı düzeylerini geniş düzeyde etkilediğini ortaya koymaktadır. Sonuçlar, öğretim düzeyleri arasında farklılığa rağmen etki büyüklük değerlerinin uygulamada kullanılan süreç odaklı yazma modeline, uygulama süresine, uygulamada kullanılan metin türüne ve uygulamanın raporlaştırıldığı yayının türüne göre anlamlı düzeyde farklılaşmadığını göstermektedir.
\end{abstract}




\section{Introduction}

Sustainability of personal and social development of individuals by expressing themselves within the context of rights, duties and responsibilities is related with their competence level of using language in a proper and effective way. Achieving this competence level is possible with systematic and planned language instruction practices. It is the same when it comes to one of most important tools of communication, namely writing which is a product of "act of thinking". A skill which is based on both individual and cooperative effort can be developed by a proper planning and suitable methods. Developing writing skill is included among the learning objectives of secondary school Turkish Teaching Curriculum.

The aims of this program include that students express their ideas and arguments about a subject as well as their feelings, thoughts, imagination, scenario and impressions by using opportunities of language properly in terms of written expression principles, then they adopt writing as their habit of self-expressing and those with good writing skills develop this competence (Ministry of National Education [MEB], 2015, p. 7). In accordance with this aim, "process-based writing model" has been adopted in teaching how to write in mother tongue. Based on this model, writing-related learning objectives have been designed as a process in which many interrelated competences are used successively; the crucial thing in the process from preparation to sharing/releasing is to help students to achieve competences related to stages of process-based writing (MEB, 2015, p. 7). In this context, especially in recent years in Turkey, process-based writing approaches are adopted in native-language instruction programs and in various instruction activities which aim to develop writing expression competences.

\section{Process-based Writing Approach}

Process approaches are characterized with instruction strategies which aimed that students should organize their thoughts before drawing up and revising their written texts. Emergence of this depends on the approach Rohman presented in 1965. In the beginnings of 1970s, Emig criticized Rohman's writing model on the basis of her empirical study on $12^{\text {th }}$ graders who spoke loudly while writing and asserted that writing process is an iterative process not linear (Boscolo, 2009, p. 366). This assertion underlies the main reference point of process-based understanding in writing instruction.

"Process-based writing approach is a writing instruction approach which views written expression studies not as a product but as a process, and on basis of students' written expression products, it reveals what students think in writing process, what they do, what characteristics writing process do have" (Kaldırım, 2014, p. 27). In process-based approaches, writing is regarded as being mainly related to language ability such as planning and making draft, and less emphasis is put on linguistic knowledge like grammar and text structure (Badger \& White, 2000). This approach suggests that "students should focus on thinking process, transfer knowledge, organize process in general and have cognitive awareness related to each stage- shortly they should be active in real terms-. It also aims to help students to achieve competences such as independent thinking, decision-making, problem-solving, learning how to learn" (Karatay, 2015, p. 25). Moreover, in the process-based writing approach, social aspects of writing are emphasized; by minimizing the verbal expression importance is paid to smallgroup works in which it is focused on problem solving, concrete materials and students' participation in writing process. Besides, thanks to positive effects of this approach on increasing motivation, at least primary school students are given freedom of choice to write in which topic they want. (Boscolo, 2009, p. 366).

There are some differences between process-based writing and traditional product- based writing. For instance, while the product-based writing approach is based on imitation, copying and teacherbased models, process-based approach focuses on participation in steps of forming a piece of work. While the principal aim of product-based writing is to create a coherent text purified from mistakes, the process-based writing defends that there is no perfect text; however a writer can get closer towards the 
perfection if he/she carries out production, reflection, discussion and revision steps while planning a text. According to Bayat (2014) this approach includes a structure which has the potential of solving problems stemming from placing the product at the focus of revision.

In the process-based writing approach, teacher and student roles are also different from the traditional product-based writing approach. In the process-based approach, teachers primarily facilitate the students' writing activities and help them reveal their potential (Badger and White, 2000). In this approach, writing is regarded as a motivational, individual and reflective activity in which teachers provide counselling with students, give them constructive feedback and provide the most suitable circumstances to write (Boscolo, 2009, p. 367). Besides, teachers do not have an evaluator position but an observer position who give feedback during the written expression. Suitably with this position, writing teachers help their students reformulate their ideas by answering their questions that help them plan their writings, and they show the students how to write (Boscolo, 2009, p. 366).

Most teachers and researchers assert that process-based writing approach encourages a flexible class structure which lets interactive learning activities between teacher-student and student-student. In this approach, the teacher has a profile suitable with the following roles: as a supporter in organizing teaching-learning activities, as a collaborator of learner, as an educator and constructive reviewer. Rather than an authoritative figure in the classroom, a teacher becomes a part of the learner group while the students change from the position of a receiver of knowledge into a position of an explorer of knowledge. This approach gives the students freedom to choose the content, interpret, evaluate and analyze the knowledge they get from various sources. Ideas are examined critically before they are regarded as persuading by the students (Dukpa, 1997, p. 20). In the process-based writing approach, it is aimed that students develop their writing competences at a quality which they can transfer into different courses and various writing situations. In this sense, it is easier for students to transfer their skills and practical knowledge to the new contexts (Guy, 2009).

Additionally, writing is an activity which requires basically cognitive competence, participation and reflection, secondly it is an analytic process that requires revision and problem solving and thirdly it is a synthetic and production-based process. In this sense, analysis and synthesis are not opposites of each other but they are parts of the productive text design circle (Sharples, 1998, p. 6). These statements towards writing also reflect the features of process-based writing. Process-based writing is an approach in which cognitive readiness and collaborative work are emphasized, multi-evaluations and improvement of higher order thinking skills such as analysis and synthesis are intended and writing process is regarded as important as product.

There are some models that can be evaluated within the process-based writing approach. The scope of this study includes $4+1$ Planned Writing and Evaluation Model, 6+1 Analytical Writing and Evaluation Model and Creative Writing Model.

4+1 Planned Writing and Evaluation Model: Planned Writing and Evaluation Model is a writing model which aims that students maintain writing activity by planning a topic and evaluating it within certain stages and the students become aware of writing process and writing product they have produced (Karatay, 2015, p. 28). In this model, stages of writing process are listed as preparation, planning, drafting, proofreading and sharing. However, these stages are not always one-direction. When a need arises, it is possible to resort to previous stages or a stage can be repeated for a few times (MEB, 2012, p. 30). This model enables written texts to be graded analytically in terms of such features as planning, language and expression, spelling \& punctuation and form (paper layout); then it enables students to focus on thinking process, to have cognitive awareness about every stage and to produce qualified writing products (Karatay, 2015. p, 38).

6+1 Analytical Writing and Evaluation Model: 6+1 Analytical Writing and Evaluation Model is a process-based writing model (Culham, 2003; DeJarnette, 2008; Karatay, 2015). This model is a design developed for purpose of answering the critical question "what does a good writing look like 
irrespective of what type it is". According to this design, writing program comprises of six dimensions listed as ideas, organization, spelling and punctuation, word choice, sentence fluency and form of expression (Culham, 2003, p. 10). 6+1 dimensional writing model helps students reflect their style and gain depth in their writings, it also helps them focus on different dimensions of writing and feel themselves as a writer. Using a rubric in order to evaluate writing within the scope of the model provides an objective point of view about writing and it also contributes to the improvement of the students' critical thinking and self-assessment skills (DeJarnette, 2008, p. 22).

Creative Writing: Creative writing is writing down feelings and ideas of an individual about an issue freely by using his/her imagination (Oral, 2008, p. 8). Writing as a creative process and as a way of expression means comprehending the message obtained from the understanding process, separating the opinions, reforming them and transferring the message as a whole. Literary creativity means actualization of the process that is the main understanding of creative studies; self-knowledge, decisionmaking after thinking, planning \& performing decisions by putting into practices (Sever as cited in Erdoğan, 2012, p. 36). Accordingly, it can be asserted that process-based writing approach and creative writing are closely related concepts. Pre-writing stage that is quite important in process-based writing approach is also present in creative writing model. At this stage, students are made to carry out some activities which prepare them for writing and they get ready for writing topics thanks to these activities (Erdoğan, 2012, p. 46). In addition, Öztürk (2007) also points out that a writing should have such aspects as opinions, organization, form of expression, word choice, sentence fluency and mechanics in order to be creative. Creative writing is considered within the same roof of the process-based writing approaches because these aspects are also sub-components of $6+1$ analytic writing and evaluation model - one of the process-based writing approaches.

After adopting "writing as a process" approach in writing instruction area in Turkish Language Teaching Curriculum, many studies have been done in order to identify the effect of practices conducted based on this approach on students' writing success. But there is not any meta-analysis study in Turkey which analyzes the studies investigating the effect of various writing instruction methods on writing achievement of students. Studies conducted in the field of writing instruction are generally those in which thesis and dissertations are analyzed and classified in terms of target group, research method, teaching method, assessment \& evaluation and content (Coşkun, Balcı \& Özçakmak, 2013; Elbir \& Yıldız, 2012; Tok \& Potur, 2015; Uyar, 2016). In one of these studies, Uyar (2016) has analyzed thesis and dissertations written between 1990-2015 in Turkey whose sample groups include primary, secondary and high school students. Studies have been classified into four themes as "pre-practices for enriching the content of written expression, instructional interventions for increasing the quality of written expression, contribution of assessment \& evaluation studies to written expression and use of technology in improvement of written expression skills". As a result of the analysis, it is found out that more studies are conducted under two themes: instructional interventions for increasing the quality of written expression and pre-practices made for enriching the content of written expression. In the study, it is expressed that "Analytic Writing and Evaluation Model" practices which put emphasize on components of text have become widespread in Turkey. Moreover, stages of writing process are claimed in the study, and it is identified that there is no terminological unity among the studies conducted within the context of process-based writing. In another study, Tok and Potur (2015) examined 126 theses, 38 dissertations and 127 articles written between 2010-2014 in Turkey about writing instruction in terms of target group, related area, method and tendencies in writing instruction by using content analysis. As a result of the research, it is concluded that most of the studies about writing instruction were conducted at secondary school level, they generally focused on effectiveness of methods used in writing, writing texts in different types and writing topics, quantitative methods were relatively used more than qualitative methods. In another study conducted by Coşkun, Balcı and Özçakmak (2013) evaluated 168 theses and dissertations written between 1981-2010 in Turkey about writing instruction by classifying them in terms of publication year of the thesis, subject of the thesis, target group and university in which the thesis is presented. As a result of their study, they reveal that the studies are mostly 
conducted with students studying at secondary school level. Moreover, they have also found out that there are more studies looking for levels of the texts written by the students and evaluating the texts in terms of incoherence, spelling, punctuation errors, grammar mistakes and legibility. Within this scope, there is another study conducted by Elbir and Yıldız (2012). They evaluated 20 dissertations and theses written between 2005-2010 in terms of structure and content, they claim that writing skills are more studied in theses; however, writing techniques, attitudes towards writing and writing programs are also among the topics discussed in theses. In the study, it is also concluded that writing instruction depending on modern writing approaches is more effective than traditional writing instruction.

Unlike these studies in Turkey, there is a large number of meta-analysis studies about the effect of writing instruction interventions on writing achievement of students that attracts attention across the world (Bangert-Drowns, Hurley \& Wilkinson, 2004; De Glopper, van Kruiningen \& Hemmen, 2014; Gillespie and Graham, 2014; Graham, McKeown, Kiuhara and Harris, 2012; Graham \&Perin, 2007; Graham \& Sandmel, 2011; Hillocks, 1984, 1986; Koster, Tribushinina, De Jong \& Van den Bergh, 2015; Rogers \& Graham, 2008). In this meta-analysis, Hillocks (1986) synthesized 69 experimental/semiexperimental study results and studied four writing instruction methods and their effects on students' writing qualities. According to this research, presentation-based instruction that includes lecturing and teacher-centered discussions affects students' writing quality positively at $d=0.02$ level; environmental approach that meets writing targets and predicts students' collaborative participations in a specific writing process has effect at $d=0.44$; natural processes that predict students' writing in what topic they choose and reviewing their writings with positive feedbacks they take from their peers in upper level interactions has effect at $d=0.18$ and individualistic writing that includes special education with the programmed material has effect at $d=0.17$ levels. Another experimental intervention deals with focus of the instruction. There are six content/activity types that are assumed to be developed via experimental intervention. As a result, it is identified that grammar instruction has effect size $d=-0.29$; sentence combination instruction has effect size $d=0.35$; analysis of good writing models and their simulation has effect size $d=0.22$; evaluation of students based on a writing scale has effect size $d=0.36$; free writing has effect size $d=0.16$ and activities based on questioning has effect size $d=0.56$.

In another study, Bangert-Drowns et al. (2004) synthesized the data of 48 scientific studies published between 1926-1998. only one study was published before 1980 and \%75 of them were published between 1985-95 and sample groups included primary school, secondary school, high school and university students and they compared school based writing with traditional instruction. This study includes the effect size values respectively calculated depending on experimental operation, publication year, source of study (thesis or another document), situation about whether study group is chosen randomly or not, the place of comparison groups (in different or same schools), teachers of comparison groups (different or same teachers) and the situation about whether researcher has participated in the instruction or not. Besides, it has also been searched whether there is a significant difference between effect size values according to following factors; the course in which experimental operation is carried out, whether writing process is carried out in a classroom environment or another place, class level, total duration of experimental operation, time allowed for classroom writing tasks, duration of experimental operation in a week (hours), whether writing products are individual writings or not, stimulation of meta cognitive reflection and giving students feedback. As a result of the research, it has been concluded that there is a small positive effect $(d=0.17)$ of writing for purpose of learning on school success. Also, this effect on school success significantly differentiates depending on class level, time (minutes) allowed for classroom writing tasks and stimulation of meta-cognitive reflection. Accordingly, 6-8th grade students' success levels have been found statistically lower than the students at the other grades. Moreover, it has been concluded that duration of experimental operation has a statistically significant effect on writing for the purpose of learning. Accordingly, when compared to an experimental operation conducted in a shorter time than one semester, an experimental operation conducted in one semester or at a longer time has a larger effect size $(d=0.23)$. Finally, it is determined that stimulation of meta-cognitive reflection is more effective on writing $(d=0.26)$. In another study, Graham and Perin 
(2007) examined 123 experimental/semi-experimental studies conducted between 1964-2005 by using meta-analysis method in order to evaluate the effectiveness of writing instruction methods used at 412thgrades. Studies have been analyzed within 11 dimensions and weighted the average effect sizes, andeach study in these dimensions has been reported. These dimensions are teaching strategy, summarizing, peer support, product-centered targets, word processing, sentence combining, questioning, pre-writing activities, model studies, grammar instruction and process-based writing approach.

In another study, Rogers and Graham (2008) analyzed 88 studies with one sample in terms of nine experimental interventions classified as instruction of planning and preparing draft, grammar and structure instruction, product-based targets, instruction of editing strategies, writing with word processor, strengthening specific writing outputs, using pre-writing activities, instruction of sentence formation skills and instruction of paragraph writing strategies. On the other hand, by using metaanalysis method Graham and Sandmel (2011) analyzed 29 experimental/semi-experimental studies carried out at classroom levels from $1^{\text {st }}$ grades to $12^{\text {th }}$ grades, which investigated the effect of processbased writing instruction on students' writing qualities and motivations for writing. As a result of the study, it is found that process-based writing instruction has a significantly positive effect on students' writing qualities, and this effect size is found to be at moderate level (0.34). In another study within this context, Graham et al. (2012) examined the effect of writing instruction practices applied to primary school students $\left(1^{\text {st }}-5^{\text {th }}\right.$ graders), and they identified 13 writing interventions implemented in 115 studies conducted within this context. In the study, effect sizes of those experimental interventions on writing were calculated; strategy instruction, self-regulation attached strategy instruction, text structures instruction, creativity and description instruction, analytical skills instruction (handwriting, spelling or keyboard skills), grammar instruction, pre-writing activities, peer-support, product-based writing, evaluation of writing, word-processing, extra time for writing, process-based approach and comprehensive writing programs. In another study, Gillespie and Graham (2014) examined the effect of writing interventions on the quality of writings produced by the students with learning difficulties. In the study in which study groups included $1^{\text {st }}-12^{\text {th }}$ graders, effect size of 43 studies was calculated as $d=0.74$. In the study, strategy instruction, spelling, procedural simplification, prior to writing, defining objectives and process-based writing operations have positive effect on students' writing qualities but only four of them (strategy instruction=1.09; spelling=0.55; determining objectives=0.57; process-based writing $=0.43$ ) are found to be statistically significant. Within process-based writing, the research includes four studies whose effect sizes were calculated.

On the other hand, De Glopper et al. (2014) analyzed 74 process-based writing studies published between 1980-2012. Results of this analysis reveal that there is a limited number of studies about writing process in educational area, and they are carried out in unnatural environments and contextual factors in students' writings are ignored. It has been detected that writers are frequently deprived of a specific audience, writing is not integrated in bigger projects, texts are not produced actually for being read or published, communicating with others and receiving feedback is limited, writers mostly do not study with anyone to collaborate with, it is limited to collect data and make preparations about style \& topic. In another study, Koster et al. (2015) examined 32 studies with meta-analysis method which were carried out in a regular classroom environment with $4^{\text {th }}-6^{\text {th }}$ graders in order to determine effective instructional practices in writing instruction. These studies were analyzed in terms of following ten dimensions and 55 effect sizes in these dimensions have been reported: strategy instruction, instruction of text structures, pre-writing activities, peer-support, grammar instruction, feedback, evaluation, setting goals, revision and correction and process-based approach. As a result of this study, it was found that five of these categories contribute to students' writing skills at a statistically significant level. The most effective intervention on students' writing achievements is 'setting goals' $(g=2.03)$, then it is followed by strategy instruction $(g=0.96)$, instruction of texts structures $(g=0.76)$, peer-support $(g=0.59)$ and feedback $(g=0.88)$. 
When all these meta-analyses are evaluated, it is observed that in almost all of them, process-based writing is regarded as an instructional approach among other instructional approaches and they aim to detect general effect of this approach on students' writing achievements. However, there is one study only conducted on basis of process-based writing approach which aims to reveal the effect of this approach on writing success. Apart from this study of Graham and Sandmel (2011), there is found no meta-analysis study focusing on only process-based writing approach.

Within this context, the purpose of this study is to determine the general effect of process-based writing approach on students' writing achievements. It is thought that determining the effect of these approaches on writing success is important at the point of evaluating the adequacy of process-based writing practices and activities in the program. Goal and sub-goals of the study are given below:

1. To what extent process-based writing models affect students' level of writing achievement?

2. Do students' writing achievement levels significantly differ depending on teaching levels?

3. Do students' writing achievement levels significantly differ depending on process-based writing approaches in practice?

4. Do students' writing achievement levels significantly differ depending on duration of implementation (hours)?

5. Do students' writing achievement levels significantly differ depending on text style in practice (informative, narrative, free type)?

6. Do effect size values obtained from studies significantly differ depending on type of publication that reports the implementation (thesis, article)?

7. At which level do "process-based writing approaches" affect students' writing achievement levels in terms of planning, spelling, presentation, sentence fluency, opinions, form of expression, organization and word choice?

In accordance with general and sub-goals, studies in which process-based writing approach is used as independent variable have been collected considering pre-determined study characteristics and they have been synthesized after their analysis with proper statistical techniques. This study has a unique value because results of experimental studies in subject of writing instruction in Turkey are statistically integrated, and effectiveness of process-based writing approaches is evaluated depending on not only one study but multiple studies including the same experimental intervention.

\section{Method}

\section{Research Model}

Meta-analysis method has been used in the study which has been conducted for purpose of determining general effect of process-based writing approaches on students' writing achievement levels. Meta-analysis is the statistical analysis of a large collection of results from individual studies for the purpose of integrating the findings (Glass, 1976,p.3). Meta-analysis stages suggested by Ellis (2010) are followed in this study. Within this framework, related studies have been gathered together, coded, calculated an average effect size and statistical significance of average, then the variability in distribution of effect size estimates have been analyzed and results have been interpreted.

\section{Data Collection}

After a detailed literature review, within context of process-based writing in Turkey, studies which were conducted between 2007-2015 and published as a journal article or thesis have been collected. Studies reported as thesis have been accessed through general network address of YOK National Thesis Center (https://tez.yok.gov.tr/UlusalTezMerkezi/) and articles have been accessed through Ulakbim Social Sciences Databases and Google Scholar. Scanning in these databases have been done with the following keywords "writing process, writing processes, process-oriented writing, process-based writing, process approach, $6+1$ writing, $6+1$ analytic writing, analytic writing and evaluation, $4+1$ writing, planned 
writing and creative writing". As a result of scanning, 21 studies have been included into meta-analysis which meet the criteria of inclusion specified.

\section{Inclusion Criteria}

Studies should be conducted within the country and in area of Turkish instruction(1), Experimental implementation should be conducted in Turkish course(2), Studies should be quasi-experimental or experimental (3),Studies should have the characteristics of master thesis/dissertation or scientific article (4),Within scope of implementation, experimental group should experience writing instruction in $4+1$, $6+1$ or creative writing models; on the other hand, participants in control group should experience traditional writing instruction (5), Studies should include data related to sample size, standard deviation and arithmetic mean (6).

Table 1 shows the details of 21 studies which meet inclusion criteria: name of author/s, place in which study is conducted, publication type, text type, teaching level at which study is conducted, writing approach assumed in study, sample size of control and experimental groups:

Table 1.

Descriptive Statistics of Studies Included in Meta-Analysis

\begin{tabular}{|c|c|c|c|c|c|c|c|c|}
\hline Study & 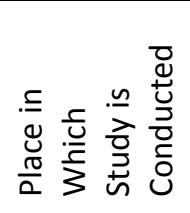 & 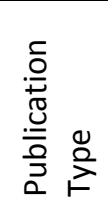 & 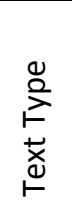 & 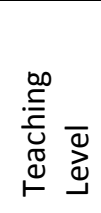 & $\begin{array}{l}\text { ఏ } \\
\text { 心 }\end{array}$ & ఏ્ & 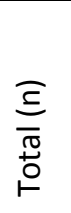 & 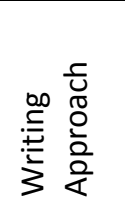 \\
\hline Ak, 2011 & İzmir & $\mathrm{T}$ & FT & $\mathrm{S}$ & 23 & 23 & 46 & $\mathrm{CW}$ \\
\hline Bayat, 2014 & Antalya & $A$ & IT & $U$ & 38 & 36 & 74 & $\begin{array}{l}\text { PW } \\
\text { General }\end{array}$ \\
\hline Beydemir, 2010 & Denizli & $\mathrm{T}$ & FT & $\mathrm{S}$ & 27 & 26 & 53 & $\mathrm{CW}$ \\
\hline $\begin{array}{l}\text { Doğan \&Müldür, } \\
2014\end{array}$ & Ankara & $A$ & NT & $\mathrm{S}$ & 57 & 52 & 109 & $\begin{array}{l}\text { PW } \\
\text { General }\end{array}$ \\
\hline $\begin{array}{l}\text { Erdoğan \&Yangın, } \\
2014\end{array}$ & Trabzon & $A$ & FT & $S$ & 27.26 & 28 & 81 & $\begin{array}{l}\text { PW } \\
\text { General }\end{array}$ \\
\hline İzdeş, 2011 & Ankara & $A$ & NT & $\mathrm{S}$ & 57 & 52 & 109 & $\begin{array}{l}\text { PW } \\
\text { General }\end{array}$ \\
\hline Kaldırım, 2014 & Kütahya & $\mathrm{T}$ & FT & $\mathrm{S}$ & 25 & 25 & 50 & $6+1$ \\
\hline Kapar Kuvanç, 2008 & İzmir & $\mathrm{T}$ & FT & $\mathrm{S}$ & 34 & 34 & 68 & $\mathrm{CW}$ \\
\hline Karatay, 2011 & $\begin{array}{l}\text { Western } \\
\text { Blacksea }\end{array}$ & $A$ & ST & $U$ & 128 & 113 & 241 & $4+1$ \\
\hline Korkmaz, 2015 & Gaziantep & $\mathrm{T}$ & FT & $\mathrm{S}$ & 32 & 29 & 51 & $\mathrm{CW}$ \\
\hline Özdemir, 2014 & Ankara & $\mathrm{T}$ & FT & $U$ & 31 & 31 & 62 & $6+1$ \\
\hline Özkara, 2007 & Ankara & $\mathrm{T}$ & NT & $\mathrm{S}$ & 35 & 35 & 70 & $6+1$ \\
\hline Öztürk, 2007 & Ankara & $\mathrm{T}$ & $\mathrm{FT}$ & $\mathrm{S}$ & 20 & 20 & 40 & $\mathrm{CW}$ \\
\hline Seban, 2012 & Unspecified & $A$ & $\mathrm{FT}$ & $P$ & 21 & 21 & 42 & $\begin{array}{l}\text { PW } \\
\text { General }\end{array}$ \\
\hline $\begin{array}{l}\text { Sever\&Memiş, } \\
2013\end{array}$ & Zonguldak & $A$ & FT & $P$ & 28.28 & 25 & 81 & $\begin{array}{l}\text { PW } \\
\text { General }\end{array}$ \\
\hline Sever, 2013 & Zonguldak & $\mathrm{T}$ & FT & $P$ & 28 & 25 & 53 & $\begin{array}{l}\text { PW } \\
\text { General }\end{array}$ \\
\hline Şentürk, 2009 & İstanbul & $\mathrm{T}$ & $\mathrm{IM}$ & $\mathrm{S}$ & 35 & 35 & 70 & $4+1$ \\
\hline Temizkan, 2011 & Ankara & $A$ & NT & $U$ & 30 & 30 & 60 & $\mathrm{CW}$ \\
\hline Tonyalı, 2010 & Düzce & $\mathrm{T}$ & $\mathrm{FT}$ & $\mathrm{S}$ & 20 & 20 & 40 & $\mathrm{CW}$ \\
\hline Ülper \&Uzun, 2009 & Ankara & A & IT & $\mathrm{S}$ & 26 & 26 & 52 & PW \\
\hline
\end{tabular}




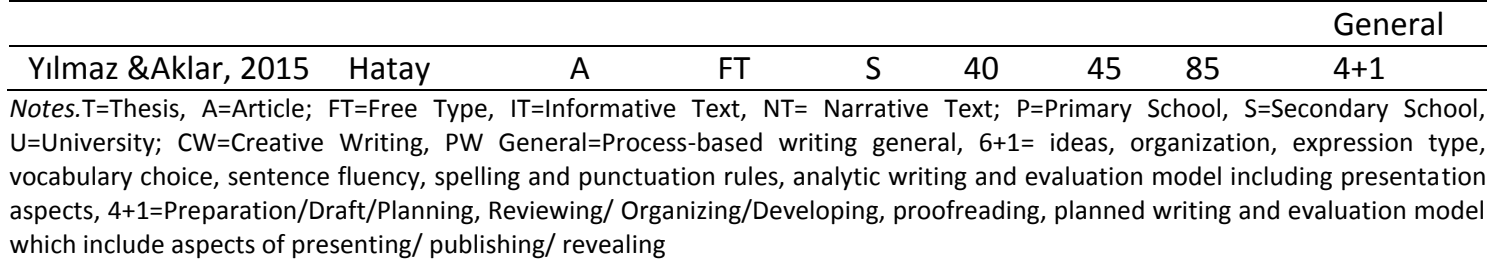

\section{Coding Process and Coding Reliability}

In meta-analysis, it is a crucial stage to code the studies and input data into data file (Cumming, 2012 , p. 234). There is a necessity to develop a coding protocol for this. According to Lipsey and Wilson (2000, p. 73), this coding protocol should consist of two stages: one section includes descriptives about study characteristics (study descriptors) and second section includes coding the data about experimental findings of study (effect size) (Lipsey \& Wilson, 2000).

Within context of this study, depending on relevant information, coding form has been developed by researcher for purpose of selecting the studies which will be included in the meta-analysis and recording the information in these studies. This coding form is divided into two sections. First section includes the name of study, author/s of study, publication year of study, place in which study is conducted, teaching level at which study is conducted, duration of implementation, publication type, writing model used in implementation, text type and writing stages. Second section includes statistical information about sample size of control and experimental group, standard deviation and arithmetic mean.

The reliability related to rater/s should also be ensured in coding process. There are two aspects of reliability related to rater/s. The first one is intra-rater reliability which is the degree of agreement among repeated evaluations performed by a single rater; the other is inter-rater reliability which is the degree of agreement among different raters. In rater reliability, rater or raters recode the studies by selecting sub-sampling among coded studies and compare the results. A single rater should get a result which do not change from one situation to another. In order to provide reliability in this way, a certain period of time should pass not to recall codes in rater's mind and this single rater should recode the studies without reference to original coding. Likewise, for inter-rater reliability, different raters should code the same study sample without referring to one another's study. In order to get a consistent reliability, 20 or more studies should be placed into reliability sample in a meta-analysis which include50 or more studies. In small meta-analysis, all studies should be used for reliability control (Lipsey \& Wilson, 2000 , p. 86). Like in primary research, it is partially possible to identify observer errors in research synthesis -by using one or more inter-rater reliability methods- (Orwin \& Vevea, 2009, p. 184-185). Cohen Kappa statistics is one of the statistical methods for identifying these errors and agreement by chance (Orwin \& Vevea, 2009, p. 187). Cohen Kappa is a coefficient which is used in determining reliability by presenting the real agreement portion by correcting the chance agreement (Sim \& Wright, 2005). In accordance with this, randomly selected 8 studies among all studies in meta-analysis have been coded by a second rater, then Cohen Kappa (Cohen's $\kappa$ ) is used for identifying the agreement portion between two independent raters. Cohen Kappa coefficient is calculated to be $\kappa=0.84$. This ratio is placed into .81-1 interval which means "almost perfect fit" according to Landis and Koch (1977) classification. Additionally, researcher has coded all studies in meta-analysis as a second time in order to ensure intra-rater reliability, missing or wrong coded studies in the first coding have been determined and necessary revisions have been done.

\section{Effect Size and Data Analysis}

"Although significance test, comparisons and parameter estimates help to enlighten the quality of group differences, they fail to evaluate the degree of correlation between independent and dependent variables." It is important to evaluate the degree of correlation in order to avoid publishing insignificant results as if they had pratical usefulness" (Tabachnick \& Fidel, 2015, p. 54). At this point, "effect size" term gains particular importance which is an index reflecting the magnitude of correlation between two 
variables. This term reflects "the proportion of variance in the dependent variable which is related with level of independent variable. Effect size can be predicted by obtaining information about levels of independent variable and it evaluates total variance in the dependent variables" (Tabachnick \& Fidel, 2015, p. 54).

Effect size is the main unit of meta-analysis studies (Borenstein, Hedges, Higgins \& Rothstein, 2013). For evaluation of obtained effect sizes, different effect size levels exist in literature which are suggested by different researchers. Effect size values obtained in this study are evaluated according to criteria suggested by Cohen $(1988$, p. 82$)$ and it is expressed with Hedge $g$ index which shows the bias corrected value of Cohen $d$ (Borenstein et al., 2013, p. 27.). If effect size values are 0.20 or below, it is interpreted as small effect; if between 0.20-0.80.it is moderate; 0.80 and above it is interpreted as a large effect. Obtained values have been analyzed by using Comprehensive Meta Analysis v2.0 "CMA" statistical program. CMA is a meta-analysis program which allows to work with multiple data types and conducts general effect size measures, subgroup analysis and tests publication bias (Borenstein et al., 2013. 372375).

\section{Validity of Study and Publication Bias}

Publication bias is a situation which results from the issue that studies with statistically significant results are more likely to be reported or published when compared to studies with statistically insignificant results (Fragkos, Tsagris \& Frangos, 2014, p. 3). Thereby, a potential emergence of publication bias is the most important factor which threatens the validity of a meta-analysis (Sutton, 2009, p. 436).

There are two statistical operation types in order to overcome publication bias in meta-analysis. The first one is publication bias identification methods; the other one is evaluation methods for effect of publication bias (Rothstein, Sutton \& Borenstein, 2005). In this study, Funnel Plot Graphic method has been preferred for the purpose of identifying publication bias, Rosenthal's Safe N Test, Orwin's Safe N Test, Begg and Mazumdar Rank Correlations Test, Duval and Tweedie Trim and Fill Method have been preferred for the purpose of evaluating publication bias effect.

Funnel Graphic:Funnel plot graph is a common visual control method used for identifying publication bias. This method is based on the assumption that research results obtained from smaller studies have more random error, and therefore they show distribution within a larger area around average effect (Fragkos et al., 2014, p. 3). The funnel plot graph of this study is as below:

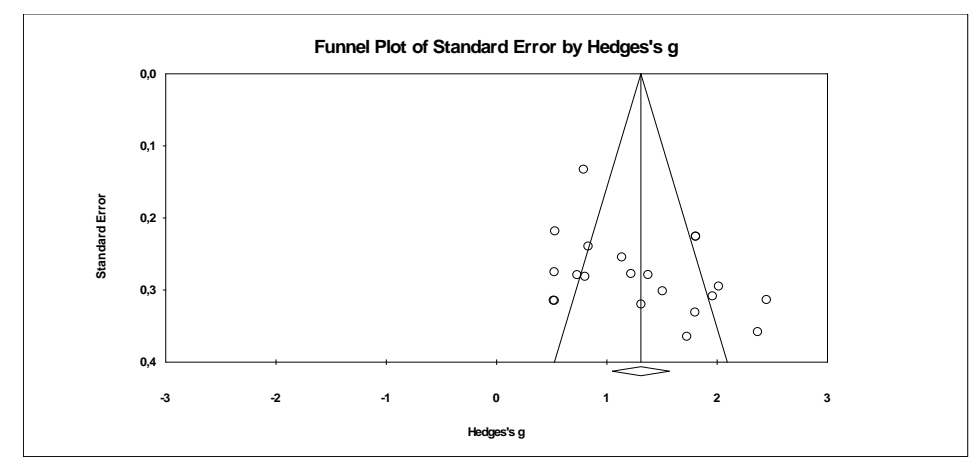

Figure 1.Funnel Plot Showing Publication Bias

When Figure 1 is reviewed, effect size values found at right and left of graphic show a symmetric distribution, and secondly effect size values found at both sides of average effect do not scatter to a large area and they have a balanced distribution. This situation indicates that there is no publication bias in meta-analysis and analysis produces results with high validity. Also, Duval and Tweedie's Trim and Fill method has been used and corrected general effect size estimate has been obtained within framework 
of meta-analysis. Corrected effect size is found to be $g=0.983$. if five studies are included into left side of funnel plot graphic, asymmetry will totally disappear which is already at acceptable level.

Rosenthal's Safe N Test:Rosenthal's Safe N Test is one of well-known statistics which aims to estimate the number of unpublished studies which is necessary for making average effect size in metaanalysis insignificant (Heene, 2010). Table 2 shows Rosenthal's Safe $\mathrm{N}$ test data which reflect publication bias in studies analyzed within meta-analysis:

Table 2.

Rosenthal's Fail-Safe N Test Data which Shows Publication Bias Situation in Publications which Form the Study Sample of Meta-Analysis

\begin{tabular}{ll}
\hline Z-value for reviewed studies & 21.67879 \\
p-value for reviewed studies & $0.00000^{*}$ \\
Alpha & 0.05000 \\
Direction & 2 \\
Z-value for Alpha & 1.95996 \\
The number of studies reviewed & 21 \\
Fail-safe Number [FSN] & 2549 \\
\hline${ }^{*} p<.05$ &
\end{tabular}

When Table 2 is reviewed, it is clearly obvious that average effect size obtained as a result of metaanalysis is significant. Removing the significance related to effect of process-based writing approaches on students' achievement and lowering it to a statistically insignificant level, there must be conducted 2549 studies with zero effect size.

Safe $\mathrm{N}$ is directly correlated with the number of studies (k) which are integrated for measuring effect size and meta-analysis. Safe $\mathrm{N}$ describes the tolerance level of a result. The purpose is to make safe $\mathrm{N}$ as high as possible, and ideally above $5 k+10$ threshold level suggested by Rosenthal (1979). The higher Safe $\mathrm{N}$ is, the more reliabile results are (Ellis, 2010, p. 122). When Table is reviewed, it is seen that Safe $\mathrm{N}$ is 2549 and it is pretty higher than 115 which is calculated by $5 k+10$ formula. This situation shows that the results obtained from meta-analysis are reliable and resistant to publication bias.

Orwin's Safe N Test:Orwin's Safe N Test is a test which allows researchers to identify specific effect size by including not only effect size of missing studies but also decreasing general effect size with inclusion of missing (Borenstein et al. as cited in Üstün \& Eryılmaz, 2014). Table 3 shows Orwin's Safe N Test data:

Table 3.

Orwin's Fail-Safe N Test Data which Shows Publication Bias Situation in Publications which Form the Study Sample of Meta-Analysis

\begin{tabular}{ll}
\hline Hedge $g$ in reviewed studies & 1.2096 \\
Criteria for a "nonsignificant" Hedge g & 0.10000 \\
Hedge $g$ mean for missing studies & 0.00000 \\
The number of necessary missing studies & 234
\end{tabular}

in order to reduce Hedge $g$ value to

below 0.1 (FSN)

According to Orwin's Safe N Test data given in Table 3.in order to lower Hedge $g=1.2096$ effect size (calculated based on random effect model) to $g=0.1$ (calculated insignificant level), there must be conducted 234 studies with zero effect size.

Begg and Mazumdar Rank Correlations Test:Begg and Mazumdar Rank Correlations Test is a test which provides the clearest understanding related to the identification of publication bias (Dinçer, 2014). Table 4 shows data related to Begg and Mazumdar Rank Correlations Test: 
Table 4.

Begg and Mazumdar Rank Correlations Test Data which Shows Publication Bias Situation in Publications which Form the Study Sample of Meta-Analysis

\begin{tabular}{ll}
\hline Kendall's S Statistic (P-Q) & 63.00000 \\
\hline $\begin{array}{l}\text { Kendall's tau coefficient } \\
\text { (with continuity correction) }\end{array}$ & 0.29665 \\
\hline $\mathrm{z}$-value for tau & 1.87221 \\
\hline $\mathrm{p}$ value & 0.06 \\
\hline
\end{tabular}

Begg and Mazumdar Rank Correlations Test is a test which reports standardized effect size and rank correlations (Kendall's Tau) between variances (or standard error) of this effect size. Tau can be interpreted as in the same way with any correlation which manifests that there is no correlation between zero effect size and accuracy, and deviations from zero indicate a correlation (Begg \& Mazumdar, 1994). Tau coefficient in this test being close to 1 and $p$ value being insignificant indicate that there is no publication bias in this study (Dinçer, 2014). Accordingly, $p=0.06$ value shows that studies included into meta-analysis are not biased.

\section{Heterogeneity Test}

\section{Findings}

Evaluation of heterogeneity is crucial in meta-analysis because existence and non-existence of real heterogeneity (variance between studies) affect the decision of meta-analyst about which statistical model he/she applies to meta-analytic database (Huedo-Medina et al., 2006). There are two models in meta-analysis as fixed effect and random effect. Under fixed effect model, real effect size is assumed to be the same for all studies included; the underlying reason for random effect model is to estimate the mean of a distribution of effects, not real effect size. In random effect model, small-scale studies despite their very small effects are not excluded in case they provide information about estimated effect of another study (Borenstein et al., 2013, p. 80-81). Heterogeneity test has been done in this study for determining whether effect size values will be interpreted based on fixed effect model or random effect model. Table 5 shows the data related to homogeneity/heterogeneity analysis under fixed effect model:

Table 5.

Findings Related to Effect Sizes of Studies According to Fixed Effects Model

\begin{tabular}{|c|c|c|c|c|c|c|c|}
\hline \multirow[t]{2}{*}{$\begin{array}{l}\text { Average } \\
\text { Effect Size } \\
(g)\end{array}$} & \multirow[t]{2}{*}{$\begin{array}{l}\text { Degree of } \\
\text { Freedom } \\
(d f)\end{array}$} & \multirow[t]{2}{*}{$\begin{array}{l}\text { Homogeneity } \\
\text { Value (Q) }\end{array}$} & \multirow{2}{*}{$\begin{array}{l}\text { Chi- } \\
\text { Square } \\
\text { Table } \\
\text { Value } \\
\left(\chi^{2}\right)\end{array}$} & \multirow[t]{2}{*}{$\begin{array}{l}\text { Standard } \\
\text { Error (SE) }\end{array}$} & \multirow[t]{2}{*}{$1^{2^{*}}$} & \multicolumn{2}{|c|}{$\begin{array}{l}\text { \%95 Confidence } \\
\text { Interval for Effect Size } \\
\left(\mathrm{ES}, \% 95_{\mathrm{Cl}}\right)\end{array}$} \\
\hline & & & & & & $\begin{array}{l}\text { Lower } \\
\text { Limit } \\
\text { (Min.) }\end{array}$ & $\begin{array}{l}\text { Upper } \\
\text { Limit } \\
\text { (Max) }\end{array}$ \\
\hline 1.210 & 20 & 102.365 & 31.410 & 0.057 & 80.462 & 1.098 & \\
\hline
\end{tabular}

*The ratio of true heterogeneity to total change in observed effect

When Table 5 is reviewed, it is seen that $Q$ value is 102 . 365. This value is pretty higher than the critical value of 31.40 determined for \%95 significance level and 29 degree of freedom in chi-square table. In addition, $I^{2}$ value is also found to be 80.462 . This value is higher than $\% 75$ ratio (accepted as high level heterogeneity) in $I^{2}$ classification suggested by Higgins and Thompson (2002). These data manifest that there is heterogeneity between studies in a real sense and effect sizes should be interpreted depending on random effect model. Furthermore, Borenstein et al. (2013, p. 86) also put forward that if studies are gathered from published literature, it is more appropriate to use random effect model. In this study, all studies included into meta-analysis have been gathered from published literature; therefore, it requires the use of random effect model. 
In this meta-analysis -limited with results of master thesis and dissertations conducted in Turkish universities and articles published in scientific journals- the importance of process-based writing approaches over development of writing competences have been analyzed depending on scientific data. Effect size, standard error and variance values of studies are given in Appendix 1. Identifying that the studies are heterogeneous, obtained effect sizes are integrated by random effect model and findings have been interpreted based on research questions. Research questions and their interpretations are given below:

\section{To what extent do the process-based writing models affect students' level of writing achievement?}

In this study, it is aimed to determine to what extent process-oriented writing approaches affect students' writing success in the face of traditional methods. Table 6 shows the findings related to the overall effect size of 21 studies in which process-oriented writing approaches were used as independent variables and the significance level of this effect size.

Table 6.

Findings Related to the Effect Sizes of the Studies according to Random Effects Model

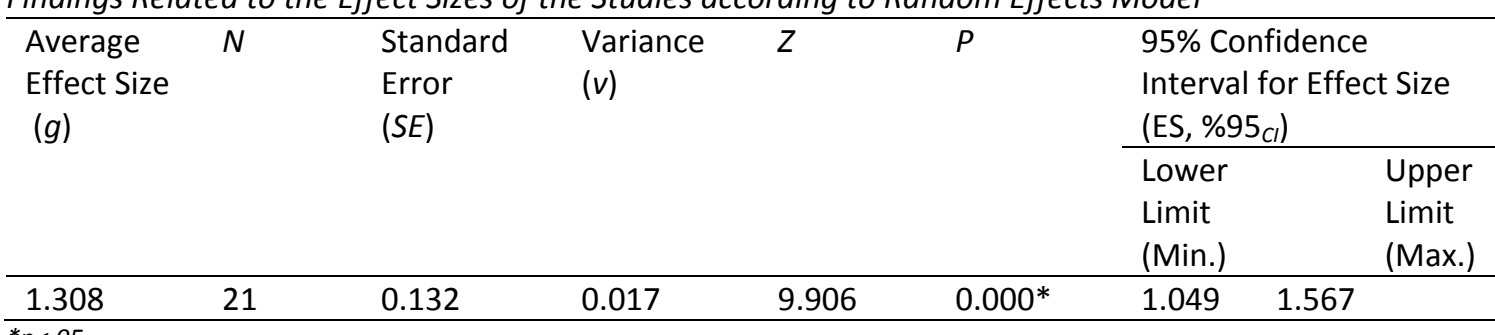

Table 6 shows that according to random effect model, effect size threshold is $g=1.049$ (\%95 confidence interval) and upper limit is $g=1.567$. Average effect size is found to be $g=1.308$ with 0.132 standard error. As there is a real heterogeneity between studies, values related to effect sizes (interpreted according to random effect model) are statistically significant $(Z=9.906 ; p=, 00)$. These data reveal that process-based writing models are effective at a large extent on students' level of writing achievement.

In meta-analysis studies conducted by different researchers which aim to level the effect of processbased writing on writing achievements of students, it is concluded that effect sizes are medium or low, not high as in this study. For instance, Hillocks (1984) made an extensive meta-analysis and stated that process approaches have a positive but small effect on writing achievements of students $(d=0$. 19). In another study conducted by Graham and Perin (2007), the effect size of 21 studies in which processbased writing approach was used as independent variable was measured as $d=0.32$. Additionally, teachers' using process-based writing approaches in their professional development affects writing quality of students at a moderate level. Gillespie and Graham (2014) revealed that process-based writing has $d=0.43$ effect size on quality of writings produced by students with learning disability. In addition, they put forward that specifically planned processes in order to develop writing stages such as planning and revising become effective only if a systematic instruction is conducted. Graham and Sandmel (2011) in their study found out that process-based writing affected quality of student writings at a statistically significant level and this effect was at medium level ( $d=0.34)$. In another study, Graham et al. (2012) calculated the effect size of studies as $d=0.40$ in which process approach was used as experimental intervention, however they concluded that this value became insignificant when they made an analysis controlling for intervening variable.

Additionally, there are meta-analysis studies in literature which do not overlap with results of this study (Graham \&Sandmel, 2011; Koster et al., 2015). In one of those studies conducted by Graham and Sandmel (2011), they argued that process-based writing did not have significant effect on developing writing skills of students-at-risk with learning disability and increasing their motivations related to 
writing. Additionally, in their study related to three studies which can be regarded within process-based writing as they include planning, writing and revising stages, Koster et al. (2015) found that the general effect size of these studies was negative $(g=-0.25)$; therefore, they concluded that process-based writing intervention did not increase writing achievements of students. This situation was attributed to the following factors: due to the limited number of studies included into meta-analysis, the results fail to reveal the systematical differences; process-based approach is a controlled variable in two studies and a more effective approach was used as an experimental operation in experimental group. At the end of study, researchers stated that process approach was more effective in writing instruction for more experienced writers, and it was less suitable for writers at beginning level. All in all, most of the findings from different meta-analysis overlap not only among themselves but also with this study. However, different from other meta-analysis conducted in the same subject and with similar purpose, this study concludes that process-based writing approaches are effective not at small or medium level but at a large extent.

\section{2) Do students' writing achievement levels significantly differ depending on the teaching levels?}

The level of instruction can be a predictor variable causing the differentiation of the result of any experimental process. It is considered knowing whether this variable is a significant variable predicting the writing success can be an important source of data related to which teaching levels the intended applications need to be concentrated on. Table 7 presents the findings related to what extent the process-oriented writing practices which were performed affect the writing success of the students who study in different levels of teaching and whether this effect is significant.

Table 7.

Findings Related to Effect Sizes according to Teaching Level at which the Study Has Been Conducted and Heterogeneity Test

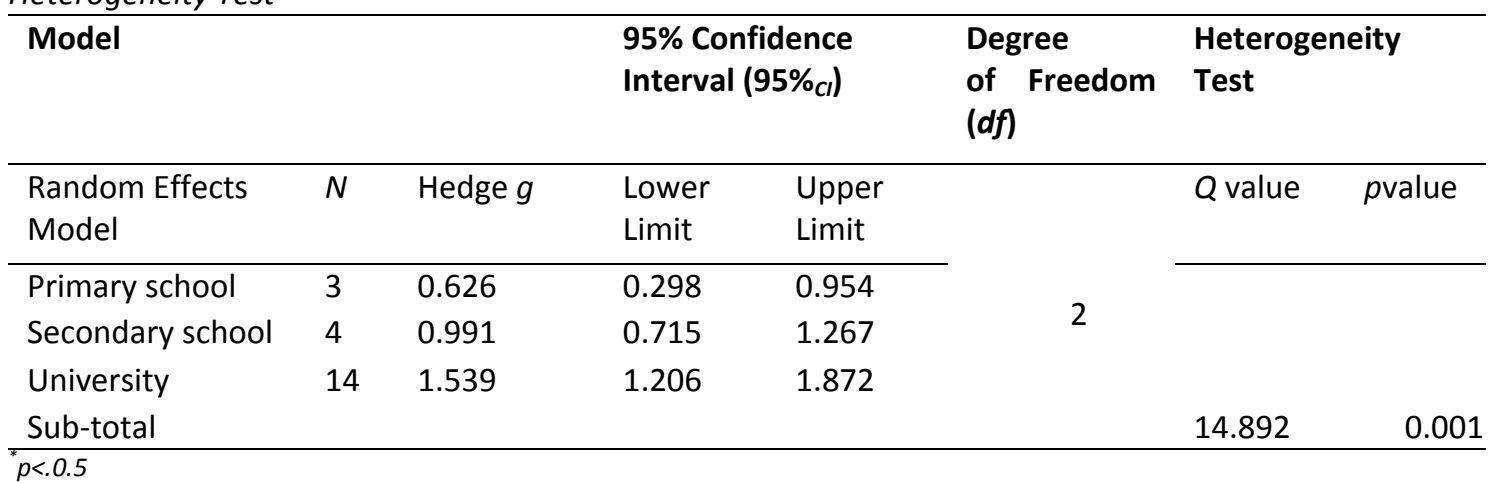

When Table 7 is reviewed, it is seen that process-based writing model practices are conducted at primary school, secondary school and university. The university is a teaching level at which most experimental practices are done (14 studies), and it is followed by secondary school (4 studies) and primary school (3 studies). When obtained effect sizes are reviewed, it is seen that there is a positive effect in all teaching levels. Also, effect of conducted practices on students' writing achievement is found to be $g=1$. 539 at university level; $g=0.991$ at secondary school and $g=0.626$ at primary school. These values manifest that process-based writing practices affect writing achievements of university and secondary school students to a large extent, but writing achievements of primary school students to a moderate extent. Also, $Q_{B}=14.892$ being higher than 5.991 critical value which is determined by 2 degree of freedom and \%95 significance level in table of $\chi 2$ indicates that effect sizes differ significantly depending on primary school, secondary and university.

This result does not overlap with results of a number of meta-analysis (Graham \&Perin, 2007; Graham \&Sandmel, 2011; Hillocks, 1986). In one of those studies conducted by Hillocks (1986), he identified that effect sizes differed significantly depending on class levels; however, he found out that these values significantly decreased as it went upward from primary school level to university level. On 
the other hand, Graham and Perin (2007) and Graham and Sandmel (2011) analyzed teaching levels within two categories (respectively 4-6 \& 7-12; 1-6 \& 7-12) and they could not find any statistical difference between teaching levels in terms of effect levels.

3) Do students' writing achievement levels significantly differ depending on process-based writing approaches in practice?

Although the understanding that speeds up process-oriented writing approaches is fundamentally the same, there are some differences in the practice phases, the activities performed and the sections related to the roles projected in the process. These differences provided with the emergence of models such as $4+1,6+1$ and Creative Writing. Table 8 shows the findings related to the analysis on the purpose of determining whether the comparison of the effects of these models on the writing success and the model selection is a significant variable predicting the overall effect sizes obtained.

Table 8.

Findings Related to the Effect Sizes according to Process-based Writing Model and Heterogeneity Test

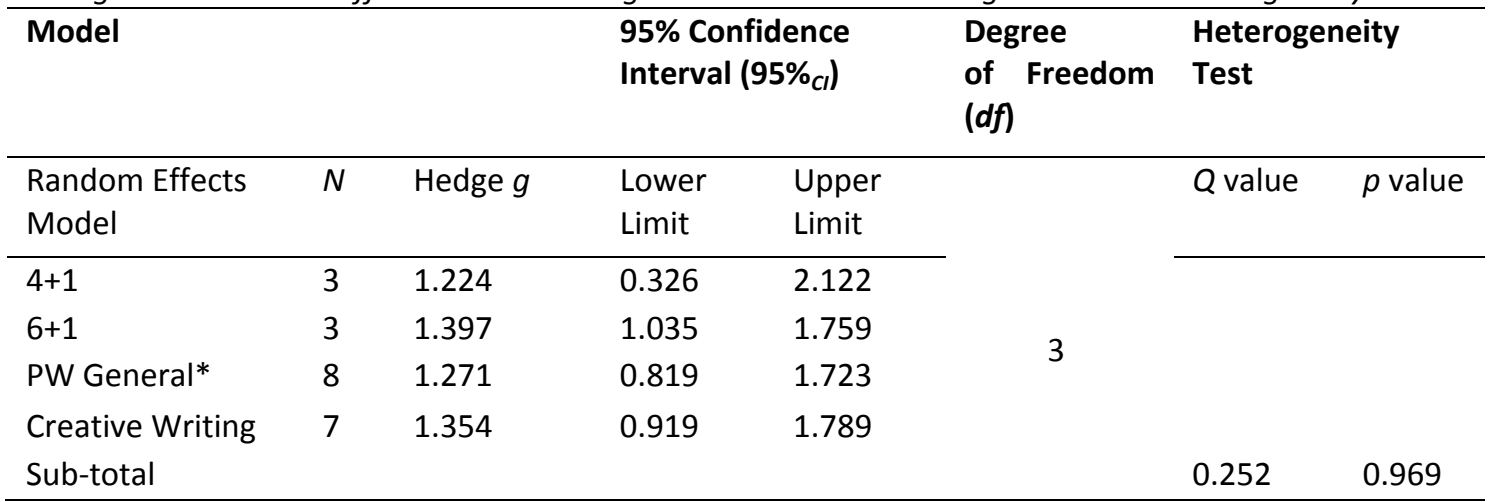

*PW General (models which are not specified as a specific model, having the title of process-based writing or including processbased writing stages in terms of content)

When Table 8 is reviewed, the most frequent practices are conducted in ( 8 studies) process-based writing model PW General (models which are not specified as a specific model, having the title of process-based writing or including process-based writing stages in terms of content). PW General is followed by creative writing ( 7 studies) and $4+1$ ( 3 studies) and $6+1$ ( 3 studies) models. Table 8 manifests that effect size in 6+1 model appears to be $g=1.397$; in creative writing model to be $g=1.354$; in PW General to be $g=1.271$ and in $4+1$ model to be $g=1.224$; they are positive and close to each other. Four models have a large effect on students' writing achievements. $Q_{B}=0.252$ being lower than 7.815 critical value which is determined by 3 degree of freedom and \%95 confidence interval in table of $\chi 2$ indicates that effect sizes do not differ significantly depending on writing models.

4) Do students' writing achievement levels significantly differ depending on duration of implementation (hours)?

The projected practice durations differ in experimental studies in which process-oriented writing approaches are used. The findings related to the moderator analysis in order to determine whether the duration of the practice has a differentiating effect on the value of the effect size are given in Table 9: 
Table 9.

Findings about Effect Sizes according to Duration of the Implementation and Heterogeneity Test

\begin{tabular}{|c|c|c|c|c|c|c|c|}
\hline \multirow{2}{*}{\multicolumn{3}{|c|}{ Model }} & \multirow{2}{*}{\multicolumn{2}{|c|}{$\begin{array}{l}\text { 95\% Confidence } \\
\text { Interval }(95 \% \text { cl })\end{array}$}} & \multirow{3}{*}{$\begin{array}{l}\text { Degree } \\
\text { of Freedom } \\
(d f)\end{array}$} & \multirow{2}{*}{\multicolumn{2}{|c|}{$\begin{array}{l}\text { Heterogeneity } \\
\text { Test }\end{array}$}} \\
\hline & & & & & & & \\
\hline $\begin{array}{l}\text { Random Effects } \\
\text { Model }\end{array}$ & $N$ & Hedge $g$ & $\begin{array}{l}\text { Lower } \\
\text { Limit }\end{array}$ & $\begin{array}{l}\text { Upper } \\
\text { Limit }\end{array}$ & & $Q$ value & $p$ value \\
\hline $14-18$ & 2 & 1.461 & 0.798 & 2.123 & & & \\
\hline $19-23$ & 7 & 1. 013 & 0.559 & 1.466 & & & \\
\hline $24-28$ & 8 & 1.510 & 1.039 & 1.982 & 4 & & \\
\hline $29-33$ & 2 & 1.825 & 1.509 & 2.141 & & & \\
\hline 33 and more & 2 & 1.038 & 0.059 & 2.017 & & & \\
\hline Sub-total & & & & & & 9.341 & 0.053 \\
\hline
\end{tabular}

When Table 9 is reviewed, it appears that eight studies include 24-28 hours implementation; seven studies include 19-23 hours. Some implementations take longer 14-18; 29-33; 33 hours and above; there are two studies related to each implementation. When effect sizes are reviewed, it is seen that the highest effect size is obtained from $(g=1.825)$ studies in which implementation takes long 29-33 hours. The lowest effect size is obtained from $(g=1.013)$ studies in which implementation takes longer 19-23 hours. Then, effect size values show that all values are positive and at a large extent. In addition, $Q_{B}=9.341$ value being lower than 9.488 critical value determined by 4 freedom of degree and \%95 confidence interval in $\chi 2$ table indicates that effect sizes do not differ significantly depending on duration of implementation. These data can be interpreted as "the increase or decrease in duration of implementation does not affect writing achievement at a significant level".

This result overlaps with result of meta-analysis conducted by Hillocks (1986). Hillocks (1986) performed binary comparisons by grouping weekly based on the durations of the studies examined in the meta-analysis. As a result of these comparisons, there was no difference between the effect sizes obtained from studies with less than 13 weeks and more studies, and there was no difference between the effect sizes of less than 17 weeks and more studies.

5) Do students' writing achievement levels significantly differ depending on text style in practice (informative, narrative, free type)?

In the studies analysed within the scope of meta-analysis, students' writing successes were determined with informative and narrative texts and the free type which the students are not restricted to writing in any type. In some studies, only informative or narrative text studies were done, but in others, two types were used. The findings obtained from the moderator analysis in order to determine the differentiation of effect sizes according to these text types are shown in Table 10: 
Table 10.

Findings about Effect Sizes according to Text Type and Heterogeneity Test

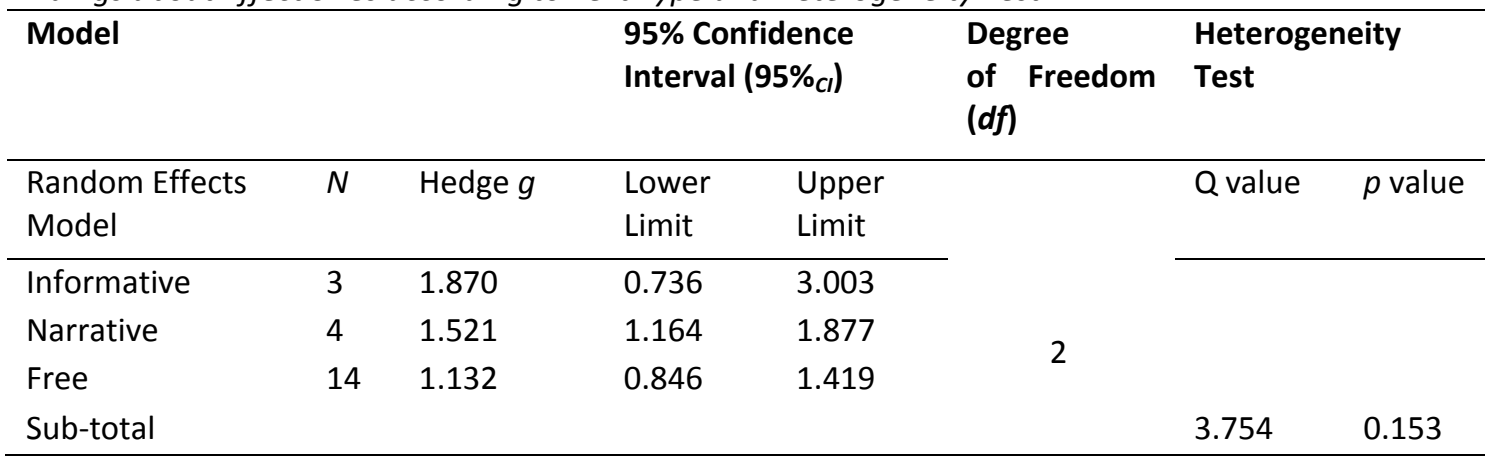

When Table 10 is reviewed, it is seen that free type $(n=14)$ is usually preferred in studies which investigate the effect of process-based writing practices on writing achievement, however narrative or informative texts are relatively less preferred (respectively $n=4 ; n=3$ ). However, the effect of processbased writing practices on writing informative text is found to be $g=1.870$; on writing narrative text to be $g=1.521$; and on writing achievement for writing free type texts to be $g=1.132$. All these values manifest that process-based writing practices are effective at a large extent on writing achievement for all text types. Although effect size values are higher in informative text type, this situation is found to be not statistically significant as $Q_{B}=3.754$ value is lower than 5.991 critical value determined by 2 degree of freedom and \%95 confidence interval in $\chi 2$ table. In other words, effect sizes do no differ significantly depending on text type (informative, narrative or free type) used in process-based writing instruction.

This result shows similarity with meta-analysis results of Graham \& Perin (2007) and Graham \&Sandmel (2011). In fact, Graham and Perin (2007) manifested that effect sizes obtained from studies in their meta-analysis did not differ significantly depending on text types (they categorized as narrative and informative text type); and also Graham and Sandmel (2011) in their study found out that effect sizes in their meta-analysis did not differ significantly depending on text types (they categorized as narrative, informative, persuasive and free text type).

6) Do effect size values obtained from studies significantly differ depending on type of publication that reports the implementation (thesis, article)?

Although dissertations and articles are similar in scientific process, they can vary from each other such as application, evaluation period, shape and scope. The moderator analysis was carried out in order to determine whether this is a case causing the effect size values obtained after the implementation to be different, and the obtained findings are given in Table 11:

Table 11.

Findings about Effect Sizes according to Publication Type and Heterogeneity Test

\begin{tabular}{|c|c|c|c|c|c|c|c|}
\hline \multirow[t]{2}{*}{ Model } & & \multirow[b]{3}{*}{ Hedge $g$} & \multirow{2}{*}{\multicolumn{2}{|c|}{$\begin{array}{l}\text { 95\% Confidence } \\
\text { Interval }\left(95 \%_{c l}\right)\end{array}$}} & \multirow{3}{*}{$\begin{array}{l}\text { Degree } \\
\text { of Freedom } \\
(d f)\end{array}$} & \multirow{2}{*}{\multicolumn{2}{|c|}{ Heterogeneity Test }} \\
\hline & & & & & & & \\
\hline $\begin{array}{l}\text { Random Effects } \\
\text { Model }\end{array}$ & $N$ & & $\begin{array}{l}\text { Lower } \\
\text { limit }\end{array}$ & $\begin{array}{l}\text { Upper } \\
\text { limit }\end{array}$ & & $Q$ value & $p$ value \\
\hline Article & 10 & 1.178 & 0.809 & 1.547 & \multirow{3}{*}{1} & & \\
\hline Thesis & 11 & 1.434 & 1.077 & 1.791 & & & \\
\hline Sub-total & & & & & & 0.955 & 0.328 \\
\hline
\end{tabular}


When Table 11 is reviewed, it comes out that while general effect size value obtained within experimental practices in 11 thesis included in meta-analysis is measured to be $g=1.434$; general effect size obtained from 10 articles is measured to be $g=1.178$. As can be seen in table, both values are positive and at a large extent. Additionally, $Q_{B}=0.955$ value is lower than 3.841 critical value determined by 1 degree of freedom and \%95 confidence interval in $\chi 2$ table indicates that obtained effect sizes do not differ significantly depending on publication type (thesis or article) in which the practice is reported. In other words, publishing the study as thesis or article does not affect the effect size at a statistically significant level.

This result is parallel with the result of Graham and Perin (2007) who revealed in their meta-analysis that effect sizes do not differ significantly depending on publication source (journal article and other publication sources). In this study, it was concluded that there is no meaningful difference between the effect size values obtained from the studies published in sources other than the journal (thesis, book, report and conference presentation) and the effect size values reported in the scientific journals.

7) At which level do "process-based writing approaches" affect students' writing achievement levels in terms of planning, spelling, presentation, sentence fluency, opinions, form of expression, organization and word choice?

Table 12 shows the results of the analysis conducted on the purpose of determining to what extent the performed practices have an effect and on which processes which are important in process-oriented writing approaches:

Table 12.

Findings about Effect Sizes according to Writing Stages and Heterogeneity Test

\begin{tabular}{|c|c|c|c|c|c|c|c|c|c|c|}
\hline & \multirow[t]{2}{*}{$\begin{array}{l}\text { Effect } \\
\text { Model }\end{array}$} & \multirow[t]{2}{*}{$\begin{array}{l}\text { Average } \\
\text { Effect } \\
\text { Size }(g)\end{array}$} & \multirow{2}{*}{$\begin{array}{l}\text { Deg } \\
\text { ree } \\
\text { of } \\
\text { Free } \\
\text { dom } \\
(d f)\end{array}$} & \multirow{2}{*}{$\begin{array}{l}\text { Homoge } \\
\text { neity } \\
\text { Value }(Q \\
\text { ) }\end{array}$} & \multirow{2}{*}{$\begin{array}{l}\text { Chi- } \\
\text { squar } \\
\text { e } \\
\text { Table } \\
\text { Value } \\
\left(\chi^{2}\right)\end{array}$} & \multirow[t]{2}{*}{$\begin{array}{l}\text { Std. } \\
\text { Error } \\
(S E)\end{array}$} & \multirow[t]{2}{*}{$I^{2^{*}}$} & \multicolumn{2}{|c|}{$\begin{array}{l}\text { 95\% Confidence } \\
\text { Interval for Effect } \\
\text { Size }(E S, \% 95 C l)\end{array}$} & \multirow[t]{2}{*}{$P$ value } \\
\hline & & & & & & & & 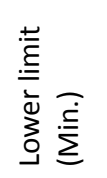 & 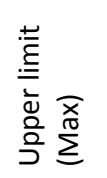 & \\
\hline $\begin{array}{l}\text { Sentence } \\
\text { fluency }\end{array}$ & REM & 1.008 & 2 & 5.110 & 5.991 & 0.157 & 60.861 & 0.701 & 1.315 & 0.078 \\
\hline Ideas & FEM & 0.930 & 2 & 2.913 & 5.991 & 0.155 & 31.347 & 0.627 & 1.234 & 0.233 \\
\hline Spelling & FEM & 1.178 & 3 & 7.723 & 7.815 & 0.136 & 61.157 & 0.912 & 1.445 & 0.052 \\
\hline Word choice & FEM & 0.838 & 2 & 1.722 & 5.991 & 0.153 & 0.000 & 0.538 & 1.138 & 0.423 \\
\hline Organization & FEM & 0.876 & 2 & 2.086 & 5.991 & 0.154 & 4.117 & 0.575 & 1.178 & 0.352 \\
\hline Presentation & FEM & 1.014 & 2 & 2.559 & 5.991 & 0.156 & 21.830 & 0.707 & 1.320 & 0.278 \\
\hline $\begin{array}{l}\text { Form of } \\
\text { expression }\end{array}$ & REM & 0.918 & 3 & 31.868 & 7.815 & 0.439 & 90.586 & 0.057 & 1.779 & $0.000^{*}$ \\
\hline Planning & REM & 1.338 & 2 & 66.401 & 5.991 & 0.919 & 96.988 & -0.463 & 3.138 & $0.000 *$ \\
\hline
\end{tabular}

In Table 12 effect sizes are clearly seen which are obtained from primary studies which report the writing achievement in different stages in process-based writing models. When these effect sizes are reviewed, it appears that process-based writing practices affect students' writing achievements in eight aspects positively and at a large extent. Three out of 21 studies report the effect of process-based writing practices on student achievements related to planning writing. Within meta-analysis which includes these three studies, average effect size $Q_{B}=66.401$ is higher than 5.991 critical value determined by 2 degree of freedom and \%95 confidence interval in $\chi 2$ table and the significance criterion is met $(p<.05)$, and heterogeneity is identified between studies; therefore, results have been 
interpreted under random effect model. The calculation under random effect model is found to be Hedge $g=1.338$. This value manifests that the aspect which process-based writing practices affect writing achievement at largest extent appears to be "planning".

Next, four out of 21 studies report the effect of process-based writing practices on student achievements related to spelling in writings. $Q_{B}=7.723$ value is lower than 7.815 critical value determined by 3 degree of freedom and \%95 confidence interval in $\chi 2$ table and significance appears to be $p<.05$; these situation necessitates that results should be interpreted under fixed effect model. Hedge $g=1.178$ value obtained in calculation under fixed effect model indicates that process-based writing practices affect writing achievement in aspect of "spelling" at a large extent. Table 12 shows the status related to the effect of process-based writing practices on students' presentation achievements. As $Q_{\mathrm{B}}=2.559$ value in table is lower than 5.991 critical value determined by 2 degree of freedom and \%95 confidence interval in $\chi 2$ table and significance appears to be $p<.05$; therefore, the results have been interpreted under fixed effect model. Hedge $g=1.014$ value obtained in calculation indicates that process-based writing practices affect writing achievement in aspect of "presentation" at a large extent. Additionally, three out of 21 studies investigate the effect of process-based writing practices on sentence fluency in students' compositions. As $Q_{B}=7.723$ value in table is higher than 5.991 critical value determined by 2 degree of freedom and \%95 confidence interval in $\chi 2$ table, results have been interpreted under random effect model.In calculation under random effect model, it is found to be Hedge $g=1.008$. This value indicates that process-based writing practices affect writing achievement in aspect of "sentence fluency" at a large extent.

In aspect of "ideas", it is noticed that $Q_{\mathrm{B}}=2.913$ value is lower than 5.991 critical value determined by 2 degree of freedom and \%95 confidence interval in $\chi 2$ table. Therefore, in calculation under fixed effect model, it is found to be Hedge $g=0.930$. This value indicates that process-based writing practices affect writing achievement in aspect of "presentation" at a large extent. Four studies investigate the effect of such practices on aspect of "form of expression". Effect sizes obtained based on statistical data in this study have been interpreted under random effect model, because $Q_{B}=31.868$ value is higher than 7.815 critical value determined by 3 degree of freedom and $\% 95$ confidence interval in $\chi 2$. Hedge $g=0.918$ value obtained under random effect model indicates that process-based writing practices affect writing achievement in aspect of "form of expression" at a large extent.

Table 12 also displays the effect of process-based writing practices on organization achivement in writings of students. As $Q_{B}=2.086$ value in table is lower than 5.991 critical value determined by 2 degree of freedom and $\% 95$ confidence interval in $\chi 2$ table and significance is $p<.05$. results have been interpreted under fixed effect model. Hedge $g=0.876$ value obtained in calculation indicates that process-based writing practices affect writing achievement in aspect "organization" at a large extent.

Lastly, related to aspect of "word choice", $Q_{B}=1.722$ value in table is lower than 5.991 critical value determined by 2 degree of freedom and $\% 95$ confidence interval in $\chi 2$ table, therefore, results have been interpreted under fixed effect model. Effect size value calculated under fixed effect model is found to be Hedge $g=0.838$. This value indicates that process-based writing practices affect writing achievement in aspect of "word choice" at a large extent.

As can be seen in meta-analysis, the effectiveness of process-based writing approaches on writing achievement takes places in planning stage. There are studies in literature which show that preliminary preparation is very important in developing written expression; however, the stage in which students have most difficulty and make most mistakes is the planning stage (Arıcl, 2008; Tekşan, 2001). At this point, it is possible to claim that process-based writing approaches are very functional and effective for helping students to overcome difficulties they experience during pre-writing stage, especially in planning dimension. 


\section{Conclusion and Recommendations}

In the area of mother-tongue instruction, it is still a debatable question which is how to make a good writing instruction. The focus of this debate is whether the purpose for writing instruction is product or the cognitive, linguistic and social competences which are to be developed within the process. In $21^{\text {st }}$ century practices of language instruction which pay attention to cognitive and meta-cognitive awareness, autonomy of learner, motivation, individual differences, social development and collaborative learning; it is argued that process is as important as product in development of writing skill. Therefore, in process-based approaches there is challenge against traditional product-based approach which limits the writing skill only with students' learning some technical knowledge. In studies conducted related to this, similar findings emerge which support this understanding, and it is concluded that writing instruction based on process-based approach increases students' writing achievements (Kaldırım, 2014; Karatay, 2011; Özkara, 2007; Sever, 2013; Şentürk, 2009; Yılmaz \& Aklar, 2015). Within this context, research is conducted for synthesizing the results obtained from individual studies and determining the effect of process-based writing approaches against traditional product-based writing approach. As a result, the effect size of 21 studies included into meta-analysis is found to be $g=1.303$; and corrected effect size is found to be $g=0.983$. The process-based writing approach with the highest effect on writing achievements of students appears to be $6+1$ analytical writing and evaluation model $(g=1.397)$, effect size of another process-based writing model $4+1$ planned writing and evaluation model- is found to be $g=1.224$. Moreover, the effect size of creative writing model is also found to be $g=1.354$; effect size of models which are not specified as a specific model, but include process-based writing stages in terms of content (abbreviated as "PW General") is found to be $g=1.271$. This finding manifests that process-based writing approaches have extensively positive effect on writing achievements of students.

According to result of intervening variable analysis based on sub-goals of meta-analysis, duration of process-based writing practices does not affect writing achievement at a significant level. The results also indicate that effect sizes do not differ significantly depending on text type (informative, narrative, free type) used in process-based writing instruction. Results obtained also indicate that effect size is not affected at a significant level depending on the situation whether study is published as a thesis or scholar article.

Research results clearly reveal that process-based writing approaches are effective at different teaching levels at different levels; and this difference between teaching levels is statistically significant. Process-based writing approaches affect writing achievements of students at secondary school and university at a large extent, however they have a moderate level effect on writing achievements of primary school students.

Within the framework of this study, the effect of process-based writing practices on different aspects of writing has also been examined. As a result of study, process-based writing practices affected writing achievement of students in eight dimensions positively and at a large extent. The effect sizes in these eight dimensions are respectively: planning $(g=1.338)$; spelling $(g=1.178)$; presentation $(g=1.014)$; sentence fluency $(g=1.008)$; ideas $(g=0.930)$, form of expression $(g=0.918)$, organization $(g=0.876)$ and vocabulary choice $(g=0.838)$.

Process-based writing is a writing approach which pays attention to all process of writing with stages, content and practice techniques and contributes to achievement of learning outcomes on the condition that it is implemented depending on a consistent planning.At this point, it becomes important that in-class and out-of-class instruction activities in practices based on process-based writing approaches should be developed in high quality which meet students' writing needs and expectations. Also, instruction time should be planned well in order to develop writing skills and sub-skills \& competences intended to be developed throughout process should be described clearly. Especially in description process, assessment tools should be used which have been developed in accordance with 
writing purposes and features of target audience. There should be put a big emphasis on following points: evaluation of effectiveness and functionality of practices in instruction process, monitoring students' writing skill developments, and conducting a process-based evaluation. An understanding for multi-evaluation should be adopted which includes student's involvement.

One of the aims of meta-analyses is to determine the fields which are needed or which are revealed to have deficiency and to be source for the further research (Oswald \&Plonsky, 2010).It is thought that this research will provide a pedagogical and theoretical fundamental for the studies to be conducted on this field. The overall effect of variables such as age, level of education, gender, book reading frequency, academic achievement, etc., which may have a predictive effect on writing, can be examined. In addition, that the Turkish lesson curriculums also include activities based on process-oriented writing stages and the application steps of these activities in more detail will make it easier to establish a certain standard in experimental studies and to evaluate the results more reliably.

\section{Limitations}

There is a threat to generalizability of meta-analysis studies: the limited number of experimental studies especially in domestic literature related to identifying the effect of various writing methods and techniques on writing achievements of students. From this point of view, in order to conduct more comprehensive meta-analysis, there is a need for studies which are at acceptable level in terms of method and quality and produce statistically interpretable findings.

When the studies in the context of meta-analysis are generally examined, it is seen that in most of the studies persistence test was not done after the last test. The results obtained from experimental studies in which persistance test is not done can produce misleading results about the actual effectiveness of experimental intervention.It is necessarily needed to test the persistency of this skill, especially considering the continuing nature of the development of writing skills and the short-term difficulty of transforming the learned knowledge into skill. This may reduce the resistance of the research results to the publication bias. On the other side, that the categorical variables may not have a numerically balanced distribution (for example, more studies are conducted at university level but the number of studies at primary and secondary levels is low) may have affected the results of the mediator analysis and may have indicated temporal results. Besides, the statistical data in the experimental studies examined was not reported separately according to process-oriented writing stages. For this reason, in the study, moderator analysis could not be done based on process-oriented writing stages and only the overall effect size values of the studies are included. This is another limitation of the research. 


\section{Türkçe Sürümü}

\section{Giriş}

Bireylerin hak, görev ve sorumluluk bilinci içinde kendilerini iyi ifade ederek kişisel ve sosyal gelişimlerinin sürekliliğini sağlamaları; dili doğru ve etkili kullanma konusundaki yetkinlik düzeyleriyle ilişsilidir. Bu yetkinlik düzeyine ulaşılması sistemli ve planlı dil öğretim uygulamalarıyla olası hâle gelir.Düşünme eyleminin bir ürünü ve iletişim kurmanın önemli araçlarından biri olan yazmada da durum benzerdir. Hem bireysel hem de iş birliğine dayalı bir beceri olan yazma, doğru bir planlamayla ve uygun yöntemlerle geliştirilebilmektedir. Yazma becerisinin geliştirilmesi ise Türkçe Dersi Öğretim Programı’nın amaçları arasında yer almaktadır.

Programda; öğrencilerin duygu, düşünce, hayal, tasarı ve izlenimleri ile bir konuda görüşlerini ve tezlerini, dilin imkânlarından yararlanarak yazılı anlatım kurallarına uygun şekilde anlatmaları, yazmayı kendilerini ifade etmede bir alışkanlığa dönüştürmeleri ve yazma yeteneği olanların bu becerilerini geliştirmeleri amaçlanmaktadır (Millî Eğitim Bakanlığı [MEB], 2015. s. 7). Bu amaç doğrultusunda yazma öğrenme alanında "süreç temelli yazma modeli" benimsenmiştir. Bu modele dayalı olarak da yazma kazanımlarının, birbiriyle ilişkili birçok becerinin art arda kullanılmasıyla gerçekleşen bir süreç şeklinde tasarlandığı; hazırlıktan başlayıp paylaşmaya/yayımlamaya uzanan süreçte önemli olanın, öğrenciye süreç temelli yazmanın aşamalarıyla ilgili beceriler kazandırmak olduğu ifade edilmektedir (MEB, 2015, s. 7). Bu bağlamda özellikle son yıllarda Türkiye'de gerek ana dil öğretim programlarında gerekse yazılı anlatım becerilerinin geliştirilmesinin amaçlandığı çeşitli öğrenme öğretme etkinliklerinde süreç odaklı yazma yaklaşımları tercih edilmektedir.

\section{Süreç Odaklı Yazma Yaklaşımı}

Süreç yaklaşımları, öğrencilerin yazılı metinlerini kaleme almadan ve gözden geçirmeden önce düşüncelerini organize etmelerini amaçlayan öğretim stratejileriyle karakterize edilmiştir. Bu yaklaşımın ortaya çıkışı Rohman'ın 1965 yılında ortaya koyduğu yaklaşıma dayanmaktadır. 1970'lerin başında Emig, yazarken yüksek sesle konuşan 12. sınıf öğrencileri üzerinde yaptığı görgül araştırmalar temelinde Rohman'ın yazma modelini eleştirmiş ve yazma sürecinin doğrusal değil yinelemeli bir süreç olduğunu ileri sürmüştür (Boscolo, 2009, s. 366). Bu iddia, yazma öğretiminde süreç odaklı anlayışın gelişiminin temel dayanak noktasını oluşturmuştur.

"Süreç odaklı yazma yaklaşımı yazılı anlatım çalışmalarını bir ürün olarak değil bir süreç olarak gören ve öğrencilerin yazılı anlatım ürünlerinden yola çıkarak yazma sürecinde neler düşündüklerini, neler yaptıklarını, yazma sürecinin ne gibi özellikler taşıdığını ortaya koymaya çalışan bir yazma öğretimi yaklaşımıdır" (Kaldırım, 2014, s. 27). Süreç yaklaşımlarında yazma; ağırlıklı olarak planlama ve taslak oluşturma gibi dilsel becerilerle ilgili görülmekte, dil bilgisi ve metin yapısı gibi dilsel bilgilere daha az önem verilmektedir (Badger ve White, 2000). Bu yaklaşım, “öğrencilerin düşünme sürecinde yoğunlaşmalarını, bilgiyi aktarmalarını, genel olarak süreci düzenlemelerini ve her aşamaya ilişkin bilişsel farkındalık sahibi olmalarını -kısaca aktif olmalarını- önermektedir. Öğrencilere öncelikle bağımsız düşünme, karar verme, problem çözme, öğrenmeyi öğrenme gibi becerileri kazandırmayı hedeflemektedir" (Karatay, 2015, s. 25). Ayrıca süreç odaklı yazma yaklaşımında yazmanın sosyal boyutuna vurgu yapılmakta; anlatımlar en aza indirgenerek somut materyallere, problem çözmeye ve öğrencilerin yazma sürecine katılmalarına odaklanılan küçük grup çalışmalarına önem verilmektedir. Bunun yanında motivasyonu arttırıcı etkisinden dolayı çocuklara en azından ilkokulda istedikleri konuda yazma konusunu seçme özgürlüğü sağlanmaktadır (Boscolo, 2009, s. 366).

Süreç odaklı yazma ile geleneksel ürün odaklı yazma arasında birtakım farklılıklar bulunmaktadır. Örneğin ürün odaklı yazma yaklaşımı taklide, kopyalamaya ve öğretmen merkezli modellere dayalıyken 562 
süreç yaklaşımı bir çalışma parçası oluşturma aşamalarına katılmaya odaklanmaktadır. Ürün odaklı yazmanın öncelikli amacı hatalardan arındırımış tutarlı bir metin oluşturmakken süreç odaklı yazma hiçbir metnin mükemmel olamayacağı ancak bir yazarın bir metni planlarken üretme, yansıtma, tartışma ve yeniden inceleme adımlarını uyguladığında mükemmelliğe yaklaşabileceğini savunmaktadır. Bayat'a (2014) göre bu yaklaşım, değerlendirmenin odağında ürünün yer almasından kaynaklanan sorunları da çözen bir yapıdadır.

Süreç odaklı yazma yaklaşımlarında öğretmen ve öğrenci rolleri de geleneksel ürün odaklı yazmadan farklıdır. Süreç yaklaşımlarında öğretmen öncelikle öğrencilerin yazma eylemlerini kolaylaştırmakta ve onların sahip olduğu potansiyeli ortaya çıkarmalarına yardımcı olmaktadır (Badger ve White, 2000). Bu yaklaşımda yazma, öğretmenlerin öğrencilere rehberlik ettiği, geri bildirim verdiği ve onlara yazmaya yönelik en uygun koşulları sağladığı motive edici, bireysel ve yansıtıcı bir etkinlik olarak görülmektedir (Boscolo, 2009, s. 367). Bunun yanında öğretmenler bir değerlendirici değil anlatım boyunca öğrencilere dönüt veren bir seyirci konumunda olmaktadır. Bu konuma uygun olarak da öğrencilerin yazılarını planlamalarına yardımcı olacak sorularını cevaplandırma yoluyla yazma esnasında onların fikirlerini yeniden formüle etmelerini sağlamakta ve onlara nasıl yazılacağını göstermektedirler (Boscolo, 2009. s. 366).

Birçok öğretmen ve araştırmacı süreç odaklı yazma yaklaşımının öğretmen-öğrenci ve öğrenciöğrenci arasında etkileşimli öğrenme etkinliklerine izin veren esnek bir sınıf yapısını teşvik ettiğ̈ini iddia etmektedir. Bu yaklaşımda öğretmen; öğretme ve öğrenme etkinliklerini organize ederken bir destekçi, öğrenen iş birlikçisi, eğitmen ve yapıcı eleştirmen rolüne uygun bir profil çizmektedir. Öğretmen sınıfta otoriter bir figürden ziyade öğrenen topluluğunun bir parçası hâline gelirken öğrenciler de bilgiyi alan değil keşfeden konumuna geçmektedir. Bu yaklaşım, öğrencilere içeriği seçme, yorumlama, değerlendirme ve çeşitli kaynaklardan elde ettikleri bilgileri analiz etme özgürlüğü vermektedir. Düşünceler, öğrenci tarafından ikna edici bulunmadan önce eleştirel olarak incelenmektedir (Dukpa, 1997, s. 20). Sürece dayalı yazma yaklaşımında öğrencilerin sadece farklı derslere değil aynı zamanda çeşitli yazma durumlarına transfer edebilecekleri nitelikteki yazma yeterliliklerini geliştirmesi amaçlanmaktadır. Bu anlayışta öğrencilerin edindikleri beceri ve uygulama bilgilerini yeni bağlamlara aktarmaları daha kolay olmaktadır (Guy, 2009).

Yazma temelde zihinsel beceri, katılım ve yansıtma gerektiren bir eylem olmasının yanında değerlendirme ve problem çözmeyi gerektiren analitik; aynı zamanda bireşimsel ve üretime dayalı bir süreçtir. Bu anlayışa göre analiz ve sentez birbirinin karşıtı değil üretken metin tasarlama döngüsünün birer parçasıdır (Sharples, 1998, s. 6). Yazmaya yönelik bu ifadeler aynı zamanda süreç odaklı yazmanın da özelliklerini yansıtmaktadır. Süreç odaklı yazma; zihinsel ön hazırlığın ve iş birlikli çalışmanın önemsendiği, çoklu değerlendirmenin ve analiz sentez gibi üst düzey düşünme becerilerinin gelişiminin amaçlandığı ve ürün kadar yazma süreçlerinin de dikkate alındığı bir yaklaşımdır.

Süreç odaklı yazma kapsamında değerlendirilebilecek bazı modeller bulunmaktadır. Söz konusu modellerden 4+1 Planlı Yazma ve Değerlendirme Modeli, 6+1 Analitik Yazma ve Değerlendirme Modeli ve Yaratıcı Yazma Modeli araştırmanın kapsamını oluşturmaktadır.

4+1 Planlı Yazma ve Değerlendirme Modeli:Planlı Yazma ve Değerlendirme Modeli öğrencilerin bir konuyu planlayarak ve belli aşamalarda değerlendirerek yazma eylemini sürdürmelerini, onların yazma sürecinin ve ortaya koydukları ürünün farkına olmalarını amaçlayan bir yazma modelidir (Karatay, 2015. s. 28). Bu modelde yazma sürecinin aşamaları sırasıyla hazırlık, planlama, taslak oluşturma, düzeltme, paylaşma şeklindedir. Ancak, bu aşamalar her zaman tek yönlü değildir. Gerekirse önceki aşamalara dönülebilir veya bir aşama birkaç kez tekrarlanabilir (MEB, 2012, s. 30). Bu model; yazılı anlatım metinlerinin planlama, dil ve anlatım, yazım ve noktalama, biçim (kâğıt düzeni) özellikleri bakımından analitik olarak puanlanabilmesini; öğrencilerin düşünme sürecinde yoğunlaşmalarını; her aşamaya ilişkin bilişsel farkındalık sahibi olmalarını ve nitelikli yazma ürünleri ortaya koymalarını sağlamaktadır (Karatay, 2015, s. 38). 
6+1 Analitik Yazma ve Değerlendirme Modeli:6+1 Analitik Yazma ve Değerlendirme Modeli sürece dayalı bir yazma modelidir (Culham, 2003; DeJarnette, 2008; Karatay, 2015). Bu model, yazı türü ne olursa olsun güzel bir yazı nasıl görünmelidir sorusuna yanıt vermek amacıyla geliştirilmiş bir tasarımdır. Bu tasarıma göre yazma programı; düşünceler, organizasyon, imla, kelime seçimi, cümle akıcılığı ve üslup olarak sıralanan altı boyut ve sunumdan oluşur (Culham, 2003. s. 10). 6+1 boyutlu yazma modeli, öğrencilerin yazılarına üslup ve derinlik katmalarına yardımcı olmakta ve yazının farklı boyutlarına odaklanarak gerçek bir yazar gibi hissetmelerini sağlamaktadır. Model çerçevesinde yazmanın değerlendirilmesi amacıyla rubrik kullanııması; yazıya yalnızca objektif bir bakış açısı sunmamakta aynı zamanda öğrencilerin eleştirel düşünmelerine ve öz değerlendirme becerilerinin gelişimine katkı sağlamaktadır (DeJarnette, 2008, s. 22).

Yaratıı yazma:Yaratıcı yazma, kişinin bir konudaki duygu ve düşüncelerini hayal gücünü kullanarak özgürce kâğıda dökmesidir (Oral, 2008, s. 8). Yazma, yaratıcı bir süreç ve anlatma tekniği olarak anlama sürecinden gelen iletinin kavranması, düşüncelerin ayrıştırılması, yeniden biçimlendirilip bir bütün olarak aktarıımasıdır. Yazınsal yaratıcılık, yaratıcı çalışmaların temel anlayışı olan kendini tanıma, düşünerek karar verme, planlama, bu plan ve kararları eyleme dönüştürme sürecinin uygulamalarla yaşama geçirilmesidir (Sever'den aktaran Erdoğan, 2012, 36). Buna göre süreç odaklı yazma yaklaşımı ile yaratıcı yazmanın birbiriyle çok yakından ilişkili iki kavram olduğu söylenebilir. Yaratıcı yazma modelinde de süreç odaklı yazma yaklaşımında oldukça önemli olan yazma öncesi aşama bulunmaktadır. Bu aşamada öğrencilere yazmaya hazırlayıcı etkinlikler yaptırılmakta, bu etkinlikler ile öğrencilerin yazma konusuna hazır olmaları sağlanmaktadır (Erdoğan, 2012, s. 46). Bunun yanında Öztürk (2007) bir yazının yaratıcı olması için fikirler, organizasyon, üslup, kelime seçimi, akıcı cümle ve mekanikler boyutlarına sahip olması gerektiğini ifade etmektedir. Bu boyutlar aynı zamanda süreç odaklı yazma yaklaşımlarından 6+1 analitik yazma ve değerlendirme modelinin de alt bileşenlerini oluşturduğundan yaratıcı yazma, süreç odaklı yazma yaklaşımları çatısı altında ele alınmıştır.

Türkçe Dersi Öğretim Programı́nda yazma öğrenme alanında süreç odaklı yazma yaklaşımının benimsenmesinin ardından bu yaklaşıma dayalı olarak gerçekleştirilen uygulamaların öğrencilerin yazma başarı düzeyleri üzerindeki etkisi, çeşitli araştırmalarla belirlenmeye çalışıımaktadır.Ancak Türkiye'de çeşitli yazma öğretim yöntem ve tekniklerinin öğrencilerin yazma başarıları üzerindeki etkisini inceleyen araştırmaların meta analiz yöntemiyle incelendiği bir çalışma bulunmamaktadır. Yazma öğretimi alanında yapılan çalışmalar genellikle yüksek lisans ve doktora tezlerinin hedef kitle, araştırma yöntemi, kullanılan öğretim yöntemi, ölçme değerlendirme ve içerik gibi açılardan incelendiği ve tasnif edildiği araştırmalardır (Coşkun, Balıı ve Özçakmak, 2013; Elbir ve Yıldız, 2012; Tok ve Potur, 2015; Uyar, 2016). Bu çalışmalardan birindeUyar (2016) 1990-2015 yılları arasında Türkiye'de hazırlanmış ve çalışma grubunu ilkokul, ortaokul ve lise düzeyinde öğrenim gören öğrencilerin oluşturduğu lisansüstü tezleri incelemiştir. Araştırma kapsamında incelenen çalışmalar; yazılı anlatımın içeriğini zenginleştirmeye yönelik ön uygulamalar, yazıı anlatımın niteliğini artırmaya yönelik öğretimsel müdahaleler, ölçme değerlendirme çalışmalarının yazılı anlatıma katkısı ve teknolojinin yazıı anlatım becerilerinin geliştirilmesinde kullanımı olmak üzere dört temaya göre sınıflandırımışır. Yapılan analiz sonucunda yazılı anlatımın niteliğini artırmaya yönelik öğretim müdahaleleri ve yazılı anlatımın içeriğini zenginleştirmeye yönelik ön uygulamalar temaları altında ele alınabilecek araştırmaların daha fazla yapıldığı belirlenmiştir. Çalışmada "Analitik Yazma Değerlendirme Modeli" gibi metnin bileşenlerine yönelik uygulamaların ülkemizde yaygınlık kazanmaya başladığı ifade edilmiştir. Çalışmada ayrıca yazma sürecinin aşamalarına değinilmiş ve süreç odaklı yazma kapsamında değerlendirilebilecek çalışmalarda terminolojik bir birlik olmadığı ifade edilmiştir. Başka bir çalışmada Tok ve Potur (2015) 2010-2014 yılları arasında yazma eğitimi alanında yapılan 126 yüksek lisans ve 38 doktora tezi ile 127 makaleyi hedef kitle, ilişkili alan, kullanılan yöntem ve yazma eğitimindeki eğilimler bakımından içerik analizi ile incelemişlerdir. Araştırma sonucunda yazma eğitimi alanında yapılan çalışmaların çoğunluğunun ortaokul düzeyinde gerçekleştirildiği; genellikle yazmada kullanılan yöntemlerin etkililiği, farklı türlerde metin yazma ve yazım konuları üzerinde yoğunlaştığı ve çalışmalarda nicel yöntemlerin görece daha fazla kullanıldığı sonucuna varıımıştır. Diğer bir çalışmada Coşkun, Balcı ve Özçakmak (2013) Türkiye'de 
yazma eğitimi alanında 1981-2010 yılları arasında yapılan 168 lisansüstü tezi; tezin yayımlandığı yıl, konu alanı, hedef grup ve tezin sunulduğu üniversite açısından sınıflandırarak değerlendirmişlerdir. Yaptıkları araştırma sonucunda çalışmaların benzer şekilde en çok ortaokul düzeyinde öğrenim gören öğrencilerle gerçekleştirildiğini belirlemişlerdir. Bunun yanında öğrencilerin oluşturduğu metinlerin düzeyini belirlemeye yönelik olarak ve yine metinlerin tutarsızlık, imla, noktalama hatası, dil bilgisel yanlışlık ve okunabilirlik açısından değerlendirilmesini öngören çalışmaların daha fazla olduğunu ortaya koymuşlardır. Bu kapsamda ele alınacak diğer bir çalışma ise Elbir ve Yıldız (2012) tarafından yapılımıştır. Elbir ve Yıldız (2012) 2005-2010 yılları arasında yazılan 20 doktora ve yüksek lisans tezini dış yapı ve içerik bakımından değerlendirdikleri çalışmanın sonucunda; tezlerde yazma becerisi üzerine daha fazla çalışıldığı, bunun yanında yazma tekniği, yazmaya karşı tutum ve yazma programının da ele alınan konular arasında yer aldığını belirlemişlerdir. Çalışmada ayrıca çağdaş yaklaşımlara uygun yazma eğitiminin, geleneksel yazma eğitimine oranla daha etkili olduğu sonucuna varılmıştır.

Türkiye'de yapılan bu çalışmaların aksine dünya ölçeğinde yazma öğretimi müdahalelerin öğrencilerin yazma başarıları üzerindeki etkisini konu alan meta analiz çalışmalarının fazlalığı dikkat çekmektedir (Bangert-Drowns, Hurley ve Wilkinson, 2004; De Glopper, van Kruiningen ve Hemmen, 2014; Gillespie ve Graham, 2014; Graham, McKeown, Kiuhara ve Harris, 2012; Graham ve Perin, 2007; Graham ve Sandmel, 2011; Hillocks, 1984, 1986; Koster, Tribushinina, De Jong ve Van den Bergh, 2015; Rogers ve Graham, 2008). Hillocks (1986) yapmış olduğu meta analizde 69 deneysel/yarı deneysel çalışma sonucunu sentezleyerek yazma öğretiminin dört yöntemini ve bu yöntemlerin öğrencilerin yazma niteliklerine etkisini araştırmıştır. Buna göre anlatımı ve öğretmen odaklı tartışmayı içeren sunuma dayalı öğretim $d=0.02$; önceden tanımlanan yazma amaçlarını karşılayacak belirli bir yazma sürecine öğrencilerin iş birlikli olarak katılmalarını öngören çevresel yaklaşım $d=0.44$. öğrencilerin kendi seçtikleri konuda yazmaları ve yazdıklarını akranlarıyla da üst düzey etkileşim kurarak onlardan olumlu geri bildirim alma yoluyla gözden geçirmelerini öngören doğal süreçler $d=0.18$ ve programlanmış materyalle özel eğitimin de içinde olduğu bireyselleştirilmiş yazma $d=0.17$ oranında öğrencilerin yazma niteliklerini olumlu yönde etkilemektedir. Diğer deneysel müdahale ise öğretimin odak noktasına yoğunlaşmıştır. Bunlar deneysel müdahale ile geliştirilmesi beklenen altı içerik veya etkinlik türüdür. Bunlardan dil bilgisi öğretimi $d=-0.29$; cümle birleştirme öğretimi $d=0.35$; güzel yazma modellerinin incelenmesi ve benzetimi $d=0.22$; öğrencilerin yazma ölçeği kullanılarak değerlendirilmesi $d=0.36$; serbest yazma $d=0.16$ ve sorgulamaya dayalı etkinliklerin $d=0.56$ oranlarında etki büyüklük değerlerine sahip oldukları belirlenmiştir.

Diğer bir çalışmada Bangert-Drowns vd. (2004) 1926-1998 -çalışmalardan yalnızca biri 1980 yılı öncesine, \%75'i 1985-95 yılları arasına ait- yılları arasında yayımlanmış, çalışma grubunu ilkokul, ortaokul, lise ve üniversite öğrencilerinin oluşturduğu ve okul temelli öğrenme yönelimli yazma ve geleneksel öğretimin karşılaştııılıı̆ı 48 bilimsel çalışmanın verilerini sentezlemişlerdir. Söz konusu çalışmada deneysel işlemin bağlamı, yayım yılı, çalışmanın kaynağı (tez veya başka doküman olma durumu) çalışma grubunun tesadüfi olarak atanıp atanmama durumu, karşılaştııılan grupların bulunduğu yer (farklı veya aynı okullarda bulunma durumu), karşılaştıılan gruplardaki öğretmenler (farklı veya aynı öğretmen olma durumu) ve araştırmacının öğretime katılıp katılmama durumuna göre ayrı ayrı hesaplanan etki büyüklük değerlerine yer verilmiştir. Bunun yanında çalışmada deneysel işlemin hangi ders kapsamında yürütüldüğü, yazma işleminin sınıf ortamında veya başka bir yerde yapılma durumu, sınıf düzeyi, deneysel işlemin toplam uzunluğu, sınıftaki yazma görevlerine ne kadar süre ayrıldığı, deneysel işlemin haftada kaç saat yapıldığı, yazma ürünlerinin bireysel yazma olup olmadığı, üst bilişsel yansıtmanın harekete geçirilme durumu, öğrencilere dönüt sağlama gibi unsurlara göre etki büyüklükleri arasında farklılaşma olup olmadığı da araştııılmıştır. Araştırma sonucunda öğrenme amacıyla yazmanın okul başarısı üzerinde küçük ve olumlu bir etkisinin $(d=0.17)$ olduğu belirlenmiştir Bunun yanında başarı üzerindeki etkinin sınıf düzeyi, sınıf içi yazma görevleri için ayrılan zaman (dakika) ve üst bilişsel yansıtmanın harekete geçirilme durumuna göre anlamlı düzeyde farklılaştığı sonucuna varılmıştır. Buna göre 6-8. sınıf düzeyindeki öğrencilerin başarısı diğer sınıf düzeylerinde öğrenim gören öğrencilere oranla istatistiksel olarak daha düşük çıkmıştır. Ayrıca deneysel işlemin süresinin de öğrenme amaçlı 
yazma üzerinde istatistiksel olarak anlamlı bir etkisinin olduğu sonucuna varılmıştır. Bu doğrultuda bir eğitim öğretim dönemi veya daha uzun bir sürede gerçekleştirilen deneysel işlemin bir dönemden daha az bir sürede gerçekleştirilen deneysel işleme göre öğrenme amaçlı yazma üzerinde daha büyük bir etki büyüklüğüne $(d=0.23)$ sahip olduğu sonucuna varılmıştır. Son olarak çalışmada, üst bilişsel yansıtmanın harekete geçirilmesinin yazma üzerinde daha etkili olduğu belirlenmiştir $(d=0$. 26). Diğer bir çalışmada Graham ve Perin (2007) 4-12. sınıf düzeylerinde uygulanan yazma öğretim yöntemlerinin etkililiğini değerlendirmek amacıyla söz konusu alanda 1964-2005 yılları arasında yapılan 123 deneysel/yarı deneysel çalışmayı meta analiz yöntemiyle incelemişlerdir. Çalışmalar strateji öğretimi, özetleme, akran desteği, ürün odaklı amaçlar, kelime işleme, cümle birleştirme, sorgulama, yazma öncesi etkinlikler, model çalışmaları, dil bilgisi öğretimi ve sürece dayalı yazma yaklaşımı olmak üzere 11 boyut altında ele alınmış ve bu boyutlarda yer alan her bir çalışmanın ağırlıklandırılmış ortalama etki büyüklükleri rapor edilmiştir.

Başka bir çalışmada Rogers ve Graham (2008) 88 tek denekli çalışmayı planlama ve taslak oluşturma stratejilerinin öğretimi, dil bilgisi ve yapı öğretimi, ürüne dayalı amaçlar, düzenleme stratejilerinin öğretimi, kelime işlemciyle yazma, belirli yazma çıktılarını güçlendirme, yazma öncesi aktivitelerin kullanımı, cümle oluşturma becerilerinin öğretimi ve paragraf yazma stratejilerinin öğretimi olarak sınıflandırdığı dokuz deneysel müdahaleye göre analiz etmişlerdir. Graham ve Sandmel (2011) ise birinci ve 12. sınıflar arasındaki sınıf düzeylerinde gerçekleştirilen ve süreç odaklı yazma öğretiminin öğrencilerin yazma kalitelerine ve yazmaya yönelik motivasyonlarına etkisinin araştırıldığı 29 yarı deneysel/deneysel çalışmayı meta analiz yöntemiyle incelemişlerdir. Çalışma sonunda süreç odaklı yazmanın öğrencilerin yazılarının niteliğine istatistiksel olarak anlamlı düzeyde olumlu etki ettiği, bu etkinin ise orta düzeyde (0.34) olduğu belirlenmiştir. Bu kapsamda değerlendirilebilecek başka bir çalışmada Graham vd. (2012) ilkokul (1-5) düzeyindeki öğrencilere yazma öğretiminde kullanılan öğretim uygulamalarının etkisini araştırmışlar ve söz konusu alanda yapılan 115 çalışmada uygulanan 13 yazma müdahalesini belirlemişlerdir. Çalışmada strateji öğretimi, öz düzenleme eklemeli strateji öğretimi, metin yapıları öğretimi, yaratıcılık ve tasvir öğretimi, çözümleme becerileri öğretimi (el yazısı, heceleme veya klavye becerisi), dil bilgisi öğretimi, yazma öncesi etkinlikler, akran yardımı, ürün odaklı yazma, yazmayı değerlendirme, kelime işleme, ekstra yazma zamanı, süreç yaklaşımı ve kapsamlı yazma programları gibi deneysel müdahalelerin yazma üzerindeki etki büyüklükleri hesaplanmıştır. Diğer bir çalışmada Gillespie ve Graham (2014) öğrenme güçlüğü yaşayan öğrenciler tarafından üretilen yazıların kalitesi üzerinde yazma müdahalelerin etkisini araştırmışlardır. Araştırmada çalışma grubunu 1-12. sınıf öğrencilerinin oluşturduğu 43 çalışmanın etki büyüklük değeri $d=0.74$ olarak hesaplanmıştır. Çalışmada strateji öğretimi, imla, yöntemsel basitleştirme, yazma öncesi, amaç belirleme ve sürece dayalı yazma işlemlerinin tamamının öğrencilerin yazılarının kalitesi üzerinde olumlu etkisinin olduğu ancak bunların dördünde (strateji öğretimi=1.09; imla=0.55; amaç belirleme=0.57; sürece dayalı yazma 0.43) istatistiksel anlamlılık olduğu belirlenmiştir. Araştırmada süreç odaklı yazma kapsamında değerlendirilerek etki büyüklükleri hesaplanan dört çalışma bulunmaktadır.

De Glopper vd. (2014) ise 1980-2012 yılları arasında yayımlanan 74 sürece dayalı yazma araştırmasını analiz etmişlerdir. Analiz sonuçları, eğitim alanındaki yazma süreci araştırmalarının kısıtlı ve doğal olmayan koşullarda gerçekleştirildiğini ve öğrencilerin yazılarındaki bağlamsal faktörlerin göz ardı edildiğini ortaya koymuştur. Yazarların sıklıkla belirli bir izleyici kitlesinden yoksun olduğu, yazmanın daha büyük projelere entegre edilmediği, metinlerin gerçekten okunma ve yayımlanma amacıyla üretilmediği, üretilen metinle ilgili başkalarıyla iletişim kurma ve onlardan dönüt alma durumunun az olduğu, yazarların çoğunlukla iş birliği içinde çalışacakları birileri olmadan çalıştıkları, tür ve konu hakkında hazırlık yapma ya da bilgi toplama durumunun nadir olduğu belirlenmiştir. Başka bir çalışmada Koster vd. (2015) yazma öğretiminde kullanılan etkili öğretim uygulamalarını belirlemek amacıyla 4-6 sınıf düzeylerinde, düzenli bir sınıf ortamında gerçekleştirilen 32 çalışmayı meta analiz yöntemiyle incelemişlerdir. Bu çalışmalar strateji öğretimi, metin yapıları öğretimi, yazma öncesi etkinlikler, akran yardımı, dil bilgisi öğretimi, dönüt, değerlendirme, amaç belirleme, gözden geçirip düzeltme ve süreç yaklaşımı olmak üzere on boyutta ele alınmış ve bu boyutlardaki 55 etki büyüklüğü rapor edilmiştir. 
Çalışma sonucunda bu kategorilerden beşinin istatistiksel olarak anlamlı düzeyde öğrencilerin yazma becerilerine katkı sağladığı belirlenmiştir. Bu kategorilerden amaç belirleme $g=2.03$ ile öğrencilerin yazma başarıları üzerindeki en etkili müdahale olurken bunu strateji öğretimi $(g=0.96)$, metin yapıları öğretimi ( $g=0.76)$, akran yardımı $(g=0.59)$ ve dönüt $(g=0.88)$ izlemiştir.

Yapılan meta analiz çalışmaları değerlendirildiğinde çalışmaların tamamına yakııında diğer öğretim yaklaşımları arasında süreç odaklı yazmaya da bir öğretim yaklaşımı olarak yer verildiği ve bu yaklaşımın öğrencilerin yazma başarıları üzerindeki genel etkisinin belirlenmeye çalışıldığı görülmektedir. Ancak yalnızca süreç odaklı yazma yaklaşımı temelinde yapılmış ve bu yaklaşımın yazma başarısı üzerindeki etkisini ortaya koymayı amaçlayan tek çalışma bulunmaktadır. Graham ve Sandmel (2011) tarafından yapılan bu çalışma dışında meta analitik bakış açısıyla süreç odaklı yazma yaklaşımı temelinde yapılmış bir çalışma bulunmamaktadır.

Bu bağlamda araştırmanın amacı, süreç odaklı yazma yaklaşımlarının öğrencilerin yazma başarıları üzerindeki genel etkisini belirlemektir. Bu yaklaşımların yazma başarııına olan etkisinin belirlenmesinin, programda yer alan süreç odaklı yazma uygulamalarının ve etkinliklerinin yeterliliğinin değerlendirilmesi noktasında önemli olduğu düşünülmektedir. Araştırmanın amacı ve alt amaçları ise şu şekildedir:

1. Süreç odaklı yazma modelleri öğrencilerin yazma başarı düzeylerini ne düzeyde etkilemektedir?

2. Öğrencilerin yazma başarı düzeyleri, öğrenim gördükleri öğretim düzeylerine göre anlamlı düzeyde farklılaşmakta mıdır?

3. Öğrencilerin yazma başarı düzeyleri, uygulamada kullanılan süreç odaklı yazma modellerine göre anlamlı düzeyde farklılaşmakta mıdır?

4. Öğrencilerin yazma başarı düzeyleri, uygulama süresine (saat) göre anlamlı düzeyde farklılaşmakta mıdır?

5. Öğrencilerin yazma başarı düzeyleri, uygulamada kullanılan metin türüne (bilgilendirici, hikâye edici, serbest tür) göre anlamlı düzeyde farklılaşmakta mıdır?

6. Çalışmalardan elde edilen etki büyüklük değerleri, uygulamanın raporlaştııılığı yayımın türüne (tez, makale) göre anlamlı düzeyde farklılaşmakta mıdır?

7. Süreç odaklı yazma yaklaşımları; planlama, imla, sunum, cümle akıcılığı, fikirler, üslup, organizasyon ve kelime seçimi boyutlarında öğrencilerin yazma başarı düzeylerini ne düzeyde etkilemektedir?

Bu genel amaç ve alt amaçlar doğrultusunda süreç odaklı yazma yaklaşımının bağımsız değişken olarak kullanıldığı çalışmalar önceden belirlenen çalışma karakteristiklerine göre bir araya getirilmiş ve uygun istatistiksel tekniklerle analiz edilerek sentezlenmiştir. Çalışma, Türkiye'de yazma öğretimi alanında yapılan deneysel çalışmaların sonuçlarının istatistiksel olarak bütünleştirildiği ve bu yolla süreç odakı ıazma yaklaşımlarının etkililiğinin tek bir çalışma sonucuna değil aynı alanda yapılan ve aynı deneysel müdahalenin kullanıldığı birçok çalışmaya dayalı olarak yorumlandığı bir araştırma olma niteliği taşımaktadır.

\section{Yöntem}

\section{Araştırmanın Modeli}

Süreç odaklı yazma yaklaşımlarının öğrencilerin yazma başarı düzeyleri üzerindeki genel etkisini belirlemek amacıla yapılan bu araştırmada meta analiz yöntemi kullanılmışır. Meta analiz, bireysel çalışmalardan elde edilen geniş bir analiz koleksiyonunun bulguların birleştirilmesi amacı doğrultusunda istatistiksel olarak analiz edilmesidir (Glass 1976, s. 3). Meta analiz belirli bir etkiyi inceleyen araştırmaların sistematik olarak gözden geçirilmesini öngören bir dizi işlem olarak bir anlamda istatistiksel analizin istatistiksel analizi olarak tanımlanmakta ve araştırma sonuçlarının genellenebilirliğini değerlendirmede oldukça etkili bir yol olarak görülmektedir (Ellis, 2010. s. 94-95).

Araştırmada psikometrik meta analiz tekniği kullanılmıştır. "Psikometrik meta analiz bağımlı ve bağımsız değişkenler arasındaki ilişkinin gücü ile bu ilişkilerin şiddetini ve yönünü etkileyen düzenleyici 
değişkenlerin olası etkilerini tespit eden bir tekniktir" (Whitener'den aktaran Gürbüz ve Şahin, 2014, s. 365). Çalışmada ayrıca Ellis (2010) tarafından önerilen meta analiz aşamaları takip edilmiştir. Bu kapsamda ilgili çalışmalar bir araya getirilmiş, kodlanmış, ortak bir etki büyüklüğü ve ortalamanın istatistiksel anlamlılığı hesaplanmış, etki büyüklüğü tahminlerinin dağılımındaki değişkenlik incelenmiş ve sonuçlar yorumlanmıştır.

\section{Verilerin Toplanması}

Yapılan literatür taramasıyla Türkiye'de süreç odaklı yazma kapsamında 2007-2015 yılları arasında yapılan ve bilimsel makale veya tez olarak yayımlanan çalışmalar bir araya getirilmiştir. Söz konusu çalışmalardan tez olarak rapor edilen çalışmalara YÖK Ulusal Tez Merkezi'nin genel ağ adresinden (https://tez.yok.gov.tr/UlusalTezMerkezi/), makalelere ise Ulakbim Sosyal Bilimler Veri Tabanı ve Google Akademik üzerinden erişilmiştir. Bu alanlarda yapılan tarama; "yazma süreci, yazma süreçleri, süreç odaklı yazma, sürece dayalı yazma, süreç yaklaşımı, 6+1 yazma, 6+1 analitik yazma, analitik yazma ve değerlendirme, 4+1 yazma, planlı yazma ve yaratıcı yazma" anahtar kelimeleriyle gerçekleştirilmiştir. Yapılan taramada, belirlenen dâhil edilme ölçütlerini karşılayan 21 çalışma meta analize alınmıştır.

\section{Dâhil edilme ölçütleri (Uygunluk Ölçütleri)}

Meta analizde bir sentezcinin araştırma ve bilgi elde etme süreci boyunca tanımladığı çalışmaları açık bir uygunluk kriterine göre kodlaması gerekmektedir. Uygunluk kriterleri araştırma sorusu veya sentezin amacıyla doğal olarak uygunluk göstermelidir. Araştırma sorusu dar veya kapsamlı ise uygunluk kriterleri de bu şekilde oluşturulmalıdır (Wilson, 2009, s. 161). Bu kapsamda uygunluk ölçütleri şu şekilde belirlenmiştir:

1) Araştırmaların yurt içinde ve Türkçe öğretimi alanında yapılmış olması,

2) Deneysel uygulamanın Türkçe derslerinde gerçekleştirilmiş olması,

3) Çalışmaların yarı deneysel ya da deneysel olması,

4) Çalışmaların yüksek lisans/doktora tezi ya da bilimsel makale niteliği taşıması,

5) Uygulama kapsamında deney grubundaki katılımcılara $4+1,6+1$ ya da yaratıcı yazma modelleri kapsamında yazma öğretimi yapılırken kontrol grubundaki katılımcılara geleneksel yazma öğretimi yapılması,

6) Çalışmaların örneklem büyüklüğü, standart sapma ve aritmetik ortalama verilerini içermesi

Dâhil edilme ölçütlerini karşılayan 21 çalışmanın yazarı/yazarları, çalışmanın yapıldığı yer, yayım türü, metin türü, çalışmanın gerçekleştirildiği öğretim kademesi, çalışmada öngörülen yazma yaklaşımı ile deney ve kontrol grubu olarak belirlenen grupların büyüklüğü Tablo 1'de gösterilmiştir:

Tablo 1.

Meta Analize Dâhil Edilen Çalışmalara Iliş̧kin Betimsel Veriler

\begin{tabular}{|c|c|c|c|c|c|c|c|c|}
\hline Çalışma & 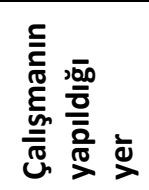 & 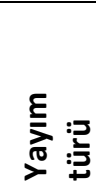 & 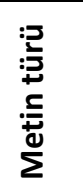 & 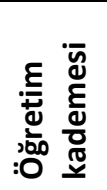 & 巨્ & $\begin{array}{l}\underline{\Xi} \\
\underline{y}\end{array}$ & $\begin{array}{l}\Xi \\
\varepsilon \\
\frac{\pi}{0} \\
\frac{\pi}{0}\end{array}$ & 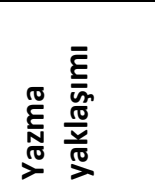 \\
\hline Ak, 2011 & İzmir & $\mathrm{T}$ & ST & 0 & 23 & 23 & 46 & YY \\
\hline Bayat, 2014 & Antalya & $\mathrm{M}$ & $\mathrm{BM}$ & $\ddot{U}$ & 38 & 36 & 74 & SOY Genel \\
\hline Beydemir, 2010 & Denizli & $\mathrm{T}$ & ST & 0 & 27 & 26 & 53 & YY \\
\hline $\begin{array}{l}\text { Doğan ve Müldür, } \\
2014\end{array}$ & Ankara & $\mathrm{M}$ & HEM & 0 & 57 & 52 & 109 & SOY Genel \\
\hline $\begin{array}{l}\text { Erdoğan ve Yangın, } \\
2014\end{array}$ & Trabzon & $M$ & ST & 0 & 27.26 & 28 & 81 & SOY Genel \\
\hline İzdeş, 2011 & Ankara & $\mathrm{M}$ & HEM & 0 & 57 & 52 & 109 & SOY Genel \\
\hline Kaldırım, 2014 & Kütahya & $\mathrm{T}$ & ST & 0 & 25 & 25 & 50 & $6+1$ \\
\hline
\end{tabular}


Kansızoğlu ve Cömert - Çukurova Üniversitesi Eğitim Fakültesi Dergisi, 46(2), 2017, 541-586

\begin{tabular}{lllllllll}
\hline $\begin{array}{l}\text { Kapar Kuvanç, } \\
2008\end{array}$ & İzmir & T & ST & O & 34 & 34 & 68 & YY \\
\hline Karatay, 2011 & Batı Karadeniz & M & ST & Ü & 128 & 113 & 241 & $4+1$ \\
\hline Korkmaz, 2015 & Gaziantep & T & ST & O & 32 & 29 & 51 & YY \\
\hline Özdemir, 2014 & Ankara & T & ST & $\ddot{U}$ & 31 & 31 & 62 & $6+1$ \\
\hline Özkara, 2007 & Ankara & T & HEM & O & 35 & 35 & 70 & $6+1$ \\
\hline Öztürk, 2007 & Ankara & T & ST & O & 20 & 20 & 40 & YY \\
\hline Seban, 2012 & Belirtilmemiş & M & ST & i & 21 & 21 & 42 & SOY Genel \\
\hline Sever ve Memiş, 2013 & Zonguldak & M & ST & i & 28.28 & 25 & 81 & SOY Genel \\
\hline Sever, 2013 & Zonguldak & T & ST & i & 28 & 25 & 53 & SOY Genel \\
\hline Şentürk, 2009 & İstanbul & T & BM & O & 35 & 35 & 70 & $4+1$ \\
\hline Temizkan, 2011 & Ankara & M & HEM & $\ddot{U}$ & 30 & 30 & 60 & YY \\
\hline Tonyalı, 2010 & Düzce & T & ST & O & 20 & 20 & 40 & YY \\
\hline Ülper ve Uzun, 2009 & Ankara & M & BM & O & 26 & 26 & 52 & SOY Genel \\
\hline Yılmaz ve Aklar, 2015 & Hatay & M & ST & O & 40 & 45 & 85 & $4+1$ \\
\hline
\end{tabular}

Notlar.T=Tez, M=Makale; ST=Serbest tür, BM=Bilgilendirici metin, HEM= Hikâye edici metin; I=Ilkokul, O=Ortaokul, Ü=Üniversite; YY=Yaratıcı yazma, SOY Genel=Süreç odaklı yazma genel, 6+1=Fikirler, düzenleme, ifade biçimi, kelime seçimi, cümle akıcılığı, imlanoktalama kuralları, sunum boyutlarını içeren analitik yazma ve değerlendirme modeli, 4+1=Hazırlık, Taslak/planlama, Gözden geçirme/düzenleme/geliştirme, düzeltme, sunum/yayımlama/paylaşma boyutlarını içeren planlı yazma ve değerlendirme modeli

\section{Kodlama Süreci ve Kodlama Güvenirliği}

Meta analizde çalışmaların kodlanması ve verilerin ana veri dosyasına girişinin yapılması önemli bir aşamadır (Cumming, 2012, s. 234). Bunun için bir kodlama protokolünün geliştirilmesi gerekmektedir. Lipsey ve Wilson'a (2000) göre bu kodlama protokolü, çalışma karakteristikleri (çalışma tanımlayıcıları) bilgisinin yer aldığı bölüm ve çalışmanın deneysel bulguları (etki büyüklükleri) ile ilgili bilgilerin kodlandığı bölüm olmak üzere iki boyuttan oluşmalıdır (Lipsey ve Wilson, 2000, s. 73).

Bu çalışma kapsamında da söz konusu bilgilere dayalı olarak meta analize dâhil edilecek çalışmaların seçilmesi ve bu çalışmalarda yer alan bilgilerin kayıt altına alınması amacıyla araştırmacı tarafından kodlama formu geliştirilmiş ve bu kodlama formu iki bölüme ayrılmıştır. Birinci bölümde çalışmanın adı, çalışmanın yazarı/yazarları, çalışmanın yayımlandığı yıl, çalışmanın yapıldığı yer, çalışmanın gerçekleştirildiği öğretim düzeyi, uygulama süresi, yayım türü, uygulamada kullanılan yazma modeli ve metin türü ile yazma aşamaları yer alırken ikinci bölümde kontrol ve deney grubunun örneklem büyüklüğü, standart sapma ve aritmetik ortalama gibi istatistiksel bilgiler bulunmaktadır.

Kodlama sürecinde kodlayııı güvenirliğinin de sağlanması gerekmektedir. Kodlayıcı güvenirliğinin genellikle iki boyutu bulunmaktadır. Bunlardan birincisi tek bir kodlayıcının durumdan duruma değişmeyen tutarlılığı, ikincisi ise farklı kodlayıcılar arasındaki tutarlılıktır. Kodlayıcı güvenirliğinde kodlanan çalışmaların bir alt örneklemi çıkartılarak kodlayıcı ya da kodlayıcıların çalışmaları tekrar kodlaması ve sonuçları karşılaştırması sağlanır. Tek bir kodlayıcının durumdan duruma değişmeyen bir sonuç elde etmesi ve bu yolla güvenirliği sağlaması için de orijinal kodlamaya referans yapılmaksızın kodlayıcının zihninde taze olmayacağı kadar yeterli zamanın geçmesi ve kodlayıcının çalışmaları tekrar kodlaması gerekmektedir. Kodlayıcılar arasındaki güvenirlikte de benzer şekilde farklı kodlayıcıların aynı çalışma örneklemini birbirlerinin çalışmalarına referans yapmaksızın kodlamaları gerekmektedir. Nispeten istikrarlı bir güvenirlik elde edebilmek için, 50 veya daha fazla çalışmanın olduğu bir meta analizde 20 veya daha fazla çalışmanın güvenirlik örneklemine alınması gerekmektedir. Küçük meta analizlerde ise güvenirlik kontrolünde tüm çalışmaların kullanılması gerekmektedir (Lipsey ve Wilson, 2000 , s. 86). Birincil araştırma uygulamalarında olduğu gibi araştırma sentezlerindeki gözlemci hatalarının da kodlayıcılar arasındaki güvenirliği belirleme yöntemlerinin bir veya daha fazlasını kullanma yoluyla ile -en azından- kısmen tahmin edilmesi mümkündür (Orwin ve Vevea, 2009. s. 184-185). Bu hataların ve şansa bağlı uzlaşmaların belirlenmesinde kullanılabilecek istatistiklerden biri de Cohen Kappa istatistiğidir (Orwin ve Vevea, 2009, s. 187). Cohen Kappa güvenirliğin belirlenmesinde kullanılan 
ve uyumun şansa bağlı olarak ortaya çıkan kısmını düzelterek gerçek uzlaşma oranını sunan bir katsayıdır (Sim ve Wright, 2005). Bu doğrultuda meta analize dâhil edilen çalışmalar arasından rastgele seçilen 8 çalışma ikinci bir kodlayıcı tarafından kodlanmış, ardından iki bağımsız kodlayıcı arasındaki uyumun değerlendirilmesi amacıyla Cohen Kappa katsayısı (Cohen's $\kappa$ ) kullanılmıştır. Yapılan hesaplamada Cohen Kappa katsayısı $k=0.84$ olarak belirlenmiştir. Bu oran Landis ve Koch (1977) sınıflandırmasına göre "neredeyse mükemmel uyum" olarak gösterilen .81-1 aralığında bulunmaktadır. Bunun yanında kodlama içi güvenirliğin sağlanması amacıyla da araştırmacı meta analize dâhil edilen çalışmaların tamamını ikinci kere kodlamış ve ilk kodlamada eksik ya da yanlış olarak kodlanan çalışmalar belirlenerek gerekli düzeltmeler yapılmıştır.

\section{Etki Büyüklüğü ve Verilerin Analizi}

“Manidarlık testi, karşılaştırmalar ve parametre kestirimleri grup farklılıklarının niteliğini aydınlatma konusunda yardımcı olsa da bağımsız değişken(ler) ve bağımlı değişken(ler)in birbiriyle ilişki derecesini değerlendiremezler. Önemsiz sonuçları, pratik kullanışlılığı varmış gibi yayınlamaktan kaçınmak için ilişki derecesinin değerlendirilmesi önemlidir" (Tabachnick ve Fidel, 2015, s. 54). Bu noktada iki değişken arasındaki ilişkinin büyüklüğünü yansıtan bir indeks olan “etki büyüklüğü" terimi ön plana çıkmaktadır. Bu terim, "bir bağımsız değişkenin düzeyleri ile ilişkilendirilen bağımlı değişken varyansı orantısını yansıtmaktadır. Etki büyüklüğü bağımsız değişkenin düzeyleri ile ilgili bilgi sahibi olmak yoluyla yordanabilirken bağımlı değişken içindeki toplam varyans miktarını değerlendirmektedir" (Tabachnick ve Fidel, 2015, s. 54).

Etki büyüklüğü meta analiz araştırmalarının temel birimidir (Borenstein, Hedges, Higgins ve Rothstein, 2013). Elde edilen etki büyüklüklerinin yorumlanmasında farklı araştırmacıların ileri sürdüğü etki büyüklük düzeyleri bulunmaktadır. Bu çalışmada elde edilen etki büyüklük değerleri Cohen (1988) tarafından önerilen ölçütlere dayalı olarak yorumlanmış ve Cohen $d^{\prime}$ nin yanlılığı düzeltilmiş değerini veren Hedge $g$ indeksi (Borenstein vd., 2013, s. 27) ile ifade edilmiştir. Buna göre, etki büyüklük değerleri; 0.20 ve altındaysa küçük (düşük); 0.20-0.80 arasındaysa orta; 0.80 ve bu değerin daha üstündeyse büyük (geniş) düzeyde bir etki olarak yorumlanmıştır. Elde edilen veriler Comprehensive Meta Analysis v2.0 "CMA" istatistik programı kullanılarak analiz edilmiştir. CMA, verilerin birçok türü ile çalışmaya imkân veren, birçok formatta genel etki büyüklüğü hesaplamaları ile alt grup analizleri ve yayın yanlılı̆̆ testleri yapılabilen bir meta analiz programıdır (Borenstein vd, 2013, s. 372-375).

\section{Araştırmanın Geçerliği ve Yayın Yanlılı̆̆ı}

Yayın yanlılı̆ı istatistiksel olarak anlamlı bir sonucun elde edildiği çalışmaların bildirilmesinin ya da yayımlanmasının istatistiksel olarak önemsiz ya da anlamsız bir çalışmaya oranla daha muhtemel olduğu düşüncesinden hareketle var olan bir durumdur (Fragkos, Tsagris ve Frangos, 201, s. 3). Dolayısıyla yayın yanlılığının potansiyel varlığı bir meta analizin geçerliğini tehdit eden en önemli unsur olarak görülmektedir (Sutton, 2009, s. 436).

Meta analizlerde yayın yanlılığının üstesinden gelebilmek için iki istatistiksel işlem türü bulunmaktadır. Bunlardan birincisi yayın yanlılı̆ının varlığını belirleme yöntemleri, ikincisi ise yayın yanlılığının etkisini değerlendirme yöntemleridir (Rothstein, Sutton ve Borenstein, 2005). Bu çalışmada araştırmanın yayın yanlılığının belirlenmesi amacıyla Huni Grafiği yönteminden, yayın yanlılığının etkisinin değerlendirilmesi amacıyla ise Rosenthal'in Güvenli N Testi, Orwin'in Güvenli N Testi, Begg ve Mazumdar Sıra Korelasyonları Testi ile Duval ve Tweedie Kes ve Ekle Yönteminden yararlanılmıştır.

Huni grafiği: Huni grafiği (funnel plot) yayın yanlılığını belirlemede kullanılan en yaygın görsel kontrol yöntemidir. Bu yöntem daha küçük çalışmalardan elde edilen araştırma sonuçlarının daha büyük tesadüfi hatası olmasından dolayı ortalama etki etrafında daha geniş bir alanda dağılım göstereceği varsayımına dayanmaktadır (Fragkos vd., 2014, s. 3). Çalışmaya ait huni grafiği şu şekildedir: 


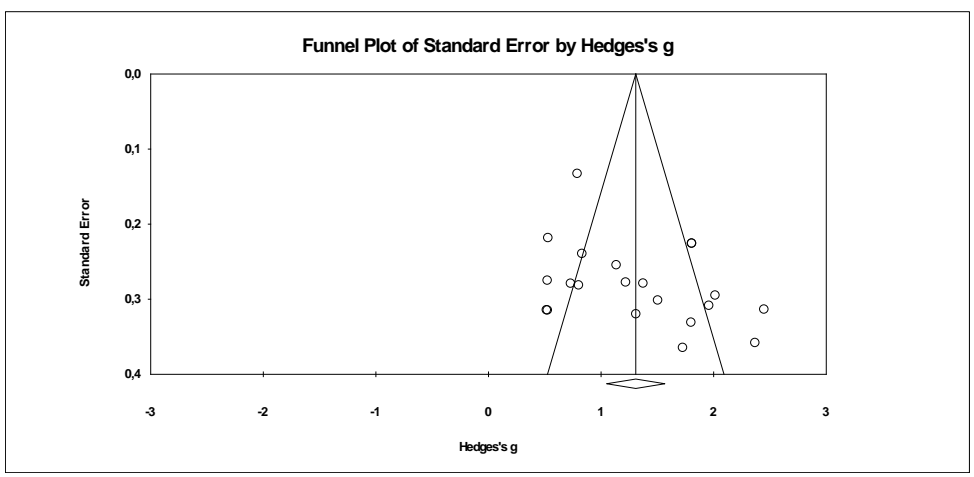

Şekil 2.Çalışma Yanlılığını Gösteren Huni Grafiği

Şekil 1 incelendiğinde grafiğin sağ ve sol yanında bulunan etki büyüklük değerlerinin simetrik bir dağılım gösterdiği, ortalama etkinin her iki yanında yer alan etki büyüklük değerlerinin çok geniş bir alana saçılmadığı ve dengeli bir dağılıma sahip olduğu anlaşılmaktadır. Bu durum, meta analizde yayın yanlılı̆ıının bulunmadığını ve analizin, geçerliği yüksek sonuçlar ortaya koyduğunu göstermektedir. Bunun yanında Duval ve Tweedie'nin Kes ve Ekle yöntemi kullanılarak meta analiz kapsamında düzeltilmiş genel etki büyüklüğü tahmini elde edilmiştir. Buna göre düzeltilmiş etki büyüklüğü $g=0.983$ olarak hesaplanmış, huni grafiğinin soluna beş çalışma daha eklendiğinde hâlihazırda kabul edilebilir düzeyde olan asimetrikliğin tamamıyla ortadan kalkacağı belirlenmiştir.

Rosenthal'in Güvenli N Testi: Rosenthal'in Güvenli N Testi meta analizlerdeki ortalama etki büyüklüğünü istatistiksel olarak anlamsız düzeye getirmek için gereken yayımlanmamış çalışmaların sayısını tahmin etmeyi amaçlayan meta analiz kapsamındaki belki de en iyi bilinen istatistiklerden biridir (Heene, 2010). Tablo 2'de meta analiz kapsamında incelenen çalışmaların yanlılık durumunu gösteren Rosenthal'in Güvenli N Testi verileri yer almaktadır:

\section{Tablo 2.}

Meta Analizin Çalışma Örneklemini Oluşturan Yayınların Yanlılık Durumunu Gösteren Rosenthal'in Güvenli N Testi Verileri

\begin{tabular}{ll}
\hline Incelenen Çalışmalar için Z-değeri & 21.67879 \\
Incelenen Çalışmalar için p-değeri & $0.00000^{*}$ \\
Alfa & 0.05000 \\
Yön & 2 \\
Alfa için Z-değeri & 1.95996 \\
Incelenen çalışma sayısı & 21 \\
Güvenli N (Fail-safe Number [FSN] & 2549 \\
\hline${ }^{*} p<05$
\end{tabular}

Tablo 2'ye bakıldığında meta analiz sonucu elde edilen ortalama etki büyüklük değerinin anlamlı olduğu görülmektedir. Bu anlamlılı̆ın ortadan kaldırılarak sürece dayalı yazma yaklaşımlarının öğrenci başarı üzerindeki etkisinin istatistiksel olarak anlamlı olmayan düzeye getirilebilmesi için etki büyüklüğü sıfır olan 2549 çalışmanın yapılması gerekmektedir.

Güvenli N sayısı, etki büyüklüğü ve meta analizde hesaplanmak üzere birleştirilen çalışmaların sayısı (k) ile doğrudan ilişkilidir. Güveli N sayısı bir sonucun tolerans düzeyini tanımlamaktadır. Amaç Güvenli N sayısını mümkün olduğunca yüksek yapmak ve ideal olarak Rosenthal (1979) tarafından önerilen $5 k+10$ alt sınır düzeyinin üzerine çıkarmaktır. Güvenli N sayısı ne kadar yüksek olursa elde edilen sonuçların güvenilirliği de o kadar yüksek olacaktır (Ellis, 2010, s. 122). Tabloya bakıldığında Güvenli N sayısının 2549 olduğu ve $5 k+10$ formülü kullanılarak hesaplanan 115 sayısının oldukça üzerinde olduğu görülmektedir. Bu durum, meta analiz sonucu elde edilen sonuçların güvenilir ve yayın yanlılığına karşı dirençli olduğunu göstermektedir. 
Orwin'in Güvenli N Testi: Orwin'in Güvenli N Testi araştırmacılara sadece kayıp çalışmaların etki büyüklüğünü değil aynı zamanda kayıp çalışmaların eklenmesiyle genel etki büyüklüğünün azalacağı spesifik etki büyüklüğü değerini de belirleme şansı veren bir testtir (Borenstein vd.'den aktaran Üstün ve Eryılmaz, 2014). Tablo 3'te Orwin'in Güvenli N Testi verileri yer almaktadır:

Tablo 3.

Meta-Analizin Çalışma Örneklemini Oluşturan Yayınların Yanlılık Durumunu Gösteren Orwin'in Güvenli N Testi Verileri

\begin{tabular}{ll}
\hline Incelenen Çalışmalardaki Hedge $g$ & 1.2096 \\
\hline “Önemsiz" bir Hedge g için ölçüt & 0.10000 \\
\hline Kayıp Çalışmalar için ortalama Hedge $g$ & 0.00000 \\
\hline $\begin{array}{l}\text { Hedge } g \text { değerini } 0.1 \text { 'in altına çekmek } \\
\text { için gereken Kayıp Çalışma Sayısı (FSN) }\end{array}$ & 234 \\
\hline
\end{tabular}

Tablo 3'te verilen Orwin'in Güvenli N Testi verilerine göre tesadüfi etkiler modeline dayalı olarak belirlenen Hedge $g=1.2096$ etki büyüklük değerinin, önemsiz olarak belirlenen $g=0.1$ değerine inmesi için etki büyüklük değeri sıfır olan 234 çalışmaya ihtiyaç duyulmaktadır.

Begg ve Mazumdar Sıra Korelasyonları Testi: Begg ve Mazumdar Sıra Korelasyonları Testi yayın yanlılığının en net şekilde anlaşılmasını sağlayan bir testtir (Dinçer, 2014). Tablo 4'te Begg ve Mazumdar Sıra Korelasyonları Testine ilişkin veriler yer almaktadır:

Tablo 4.

Meta-Analizin Çalışma Örneklemini Oluşturan Yayınların Yanlılık Durumunu Gösteren Begg ve Mazumdar Sıra Korelasyonları Testi

\begin{tabular}{|c|c|}
\hline Kendall'ın S İstatistiği (P-Q) & 63.00000 \\
\hline $\begin{array}{l}\text { Kendall'ın tau katsayısı } \\
\text { (süreklilik düzeltmesi yapılmış) }\end{array}$ & 0.29665 \\
\hline Tau için z değeri & 1.87221 \\
\hline p değeri & 0.06 \\
\hline
\end{tabular}

Begg ve Mazumdar Sıra Korelasyonları Testi, standardize edilmiş etki büyüklüğü ve bu etkilerin varyansları (veya standart hataları) arasındaki sıra korelasyonlarını (Kendall's Tau) rapor eden bir testtir. Tau, sıfır değerinin etki büyüklüğü ve kesinlik arasında ilişki olmadığını ve sıfırdan sapmaların ise bir ilişkinin var olduğunu gösterdiğini ortaya koyan herhangi bir korelasyonla hemen hemen aynı şekilde yorumlanabilir (Begg ve Mazumdar, 1994). Bu testte kullanılan Tau katsayının 1'e yakın olması ve $p$ değerinin anlamlı olmaması yayın yanlıı̆ı̆ın da olmadığını göstermektedir (Dinçer, 2014). Buna göre $\mathrm{p}=0.06$ değeri meta analize dâhil edilen çalışmaların yanlı olmadığını ortaya koymaktadır.

\section{Heterojenlik Testi}

\section{Bulgular}

Meta analizde heterojenliğin değerlendirilmesi önemli bir konudur çünkü gerçek heterojenliğin yokluğu ve varlığı (çalışmalar arası değişkenlik) meta analizi yapan kişinin meta analitik veri tabanına uygulayacağı istatistiksel modele karar vermesini etkilemektedir (Huedo-Medina vd., 2006). Meta analiz çalışmalarında sabit etki ve rastgele etkiler modeli olmak üzere iki model bulunmaktadır. Sabit etki modeli altında tüm çalışmalar için gerçek etki büyüklüğünün aynı olduğu varsayılırken rastgele etkiler modeli altındaki amaç gerçek etki büyüklüğünü değil etkilerin dağılım ortalamasını tahmin etmektir. Rastgele etkiler modelinde, çok küçük ağırlıkları olmasına rağmen küçük ölçekli çalışmalar, diğer bir çalışmanın tahminî etkisi hakkında bilgi verebileceği düşüncesiyle iptal edilmez (Borenstein vd., 2013. s. 80-81). Bu çalışmada etki büyüklük değerlerinin sabit mi yoksa rastgele etkiler modeline dayalı olarak mı 
yorumlanacağını belirlemek amacıyla heterojenlik testi yapılmıştır. Tablo 5'te sabit etkiler modeli altında bu homojenlik/heterojenlik analizine yönelik verilere yer verilmektedir:

Tablo 5.

Sabit Etkiler Modeline Göre Çalışmaların Etki Büyüklüklerine Ilişskin Bulgular

\begin{tabular}{|c|c|c|c|c|c|c|c|}
\hline \multirow{2}{*}{$\begin{array}{l}\text { Ortalama } \\
\text { Etki } \\
\text { Büyüklüğü } \\
(g)\end{array}$} & \multirow[t]{2}{*}{$\begin{array}{l}\text { Serbestlik } \\
\text { Derecesi } \\
(d f)\end{array}$} & \multirow[t]{2}{*}{$\begin{array}{l}\text { Homojenlik } \\
\text { Değeri }(Q)\end{array}$} & \multirow{2}{*}{$\begin{array}{l}\text { Ki-Kare } \\
\text { Tablo } \\
\text { Değeri } \\
\left(\chi^{2}\right)\end{array}$} & \multirow[t]{2}{*}{$\begin{array}{l}\text { Standart } \\
\text { Hata (SE) }\end{array}$} & \multirow[t]{2}{*}{$1^{2^{*}}$} & \multicolumn{2}{|c|}{$\begin{array}{l}\text { Etki Büyüklüğü } \\
\text { için \%95 Güven } \\
\text { Aralığı (ES, \%95 } 1 \text { ) }\end{array}$} \\
\hline & & & & & & $\begin{array}{l}\text { Alt Sınır } \\
\text { (Min.) }\end{array}$ & $\begin{array}{l}\text { Üst } \\
\text { Sınır } \\
\text { (Max) }\end{array}$ \\
\hline 1.210 & 20 & 102.365 & 31.410 & 0.057 & 80.462 & 1.098 & 1.321 \\
\hline
\end{tabular}

Tablo 5 incelendiğinde $Q$ değerinin 102.365 olduğu görülmektedir. Bu değer ki kare tablosunda \%95 anlamlılık düzeyi ve 20 serbestlik derecesi için belirlenen 31.410 kritik değerinin oldukça üzerindedir. Bunun yanında $I^{2}$ değerinin de 80.462 olarak hesaplandığı görülmektedir. Bu değer Higgins ve Thompson (2002) tarafından önerilen $I^{2}$ değerleri sınıflamasında yüksek düzeyde heterojenlik olarak belirlenen \%75 oranının da üzerindedir. Bu veriler, çalışmalar arasında gerçek anlamda bir heterojenliğin olduğunu ve etki büyüklüklerinin tesadüfi etkiler modeline göre yorumlanması gerektiğini göstermektedir. Bunun yanında Borenstein vd. $(2013$, s. 86$)$ çalışmalar yayımlanmış literatürden elde edildiği zaman rastgele etkiler modelinin kullanılmasının daha uygun olacağını ileri sürmektedir. Bu çalışmada da meta analize dâhil edilen çalışmaların tamamının yayımlanmış literatürden oluşması rastgele etkiler modelinin kullanılmasının gerekliliğini ortaya koymaktadır.

Türkiye' deki üniversitelerde yapılan yüksek lisans ve doktora tezleri ile bilimsel dergilerde yayımlanan makalelerden elde edilen araştırma sonuçlarıyla sınırlı olan bu meta analiz çalışmasında süreç odakllı yazma yaklaşımlarının yazma becerilerinin geliştirilmesindeki önemi bilimsel verilere dayalı olarak ele alınmıştır. İncelenen çalışmalara ait etki büyüklüğü, standart hata ve varyans değerleri $E K 1^{\prime}$ de verilmiştir. Elde edilen etki büyüklükleri, çalışmaların heterojen olduğunun belirlenmesi üzerine rastgele etkiler modeli esas alınarak birleştirilmiş ve bulgular araştırmanın sorularına dayalı olarak yorumlanmıştır.

Araştırmanın soruları ve sorulara dayalı olarak yapılan yorumlamalar şu şekildedir:

\section{1) Süreç odaklı yazma modelleri öğrencilerin yazma başarı düzeylerini ne düzeyde etkilemektedir?}

Çalışmada süreç odaklı yazma yaklaşımlarının geleneksel yöntemler karşısında öğrencilerin yazma başarılarını ne düzeyde etkilediğinin belirlenmesi amaçlanmaktadır. Süreç odaklı yazma yaklaşımlarının bağımsız değişken olarak kullanıldığı 21 çalışmaya yönelik genel etki büyüklüğü ve bu etki büyüklüğünün anlamlılık düzeyi ile ilgili bulgular Tablo 6 'da verilmiştir:

Tablo 6.

Rastgele Etkiler Modeline Göre Çalışmaların Etki Büyüklüklerine ilişkin Bulgular

\begin{tabular}{|c|c|c|c|c|c|c|c|}
\hline \multirow{2}{*}{$\begin{array}{l}\text { Ortalama } \\
\text { Etki } \\
\text { Büyüklüğü } \\
\text { (g) }\end{array}$} & \multirow[t]{2}{*}{$N$} & \multirow[t]{2}{*}{$\begin{array}{l}\text { Standart Hata } \\
(S E)\end{array}$} & \multirow[t]{2}{*}{ Varyans (v) } & \multirow[t]{2}{*}{$Z$} & \multirow[t]{2}{*}{$p$} & \multicolumn{2}{|c|}{$\begin{array}{l}\text { Etki Büyüklüğü için } \\
\text { \%95 Güven Aralığı } \\
\left(E S, \% 95_{C l}\right)\end{array}$} \\
\hline & & & & & & $\begin{array}{l}\text { Alt Sınır } \\
\text { (Min.) }\end{array}$ & $\begin{array}{l}\ddot{s t} \\
\text { Sınır } \\
(\operatorname{Max})\end{array}$ \\
\hline 1.308 & 21 & 0.132 & 0.017 & 9.906 & $0.000 *$ & 1.049 & 1.567 \\
\hline
\end{tabular}


Tablo 6'da rastgele etkiler modeline göre etki büyüklüğünün alt sınırının \%95 güven aralığında $g=1.049$; üst sınırının ise $g=1.567$ olduğu görülmektedir. Ortalama etki büyüklüğü ise 0.132 standart hata ile $g=1.308$ olarak hesaplanmıştır. Çalışmalar arasında gerçek bir heterojenlik var olduğu için rastgele etkiler modeline göre yorumlanan etki büyüklüklerine ait değerlerin istatistiksel olarak anlamlı olduğu $(Z=9.906 ; p=, 00)$ görülmektedir. Bu veriler süreç odaklı yazma modellerinin öğrencilerin yazma başarı düzeyleri üzerinde geniş düzeyde etkili olduğunu ortaya koymaktadır.

Süreç odaklı yazma yaklaşımlarının öğrencilerin yazma başarı düzeyleri üzerindeki etkisini belirlemek amacıyla farklı araştırmacılar tarafından yapılan meta analiz çalışmalarında ise etki büyüklük değerlerinin bu çalışmada olduğu gibi büyük değil; küçük ya da orta düzeyde olduğu sonucuna varılmıştır. Örneğin Hillocks (1984) tarafından yapılan kapsamlı meta analizde süreç yaklaşımlarının öğrencilerin yazma başarıları üzerinde olumlu yönde $d=0.19$ 'luk küçük bir etki büyüklüğüne sahip olduğu belirtilmiştir. Diğer bir çalışmada Graham ve Perin (2007) sürece dayalı yazma yaklaşımının bağımsız değişken olarak kullanıldığı 21 çalışmanın etki büyüklük değerini $d=0.32$ olarak hesaplamıştır. Bunun yanında öğretmenlerin mesleki gelişimlerinde süreç odaklı yazma yaklaşımını kullanmaları durumunun öğrencilerin yazma kalitelerini orta düzeyde etkilediği sonucuna varmışlardır. Gillespie ve Graham (2014) ise sürece dayalı yazmanın öğrenme güçlüğü yaşayan öğrenciler tarafından üretilen yazıların kalitesi üzerinde $d=0.43^{\prime} \mid u ̈ k$ bir etki büyüklüğüne sahip olduğunu ortaya koymuşlardır. Ayrıca planlama ve gözden geçirme gibi yazma süreçlerinin geliştirilmesi için özel olarak planlamış işlemlerin yalnızca sistemli öğretim verilmesi durumunda etkili olduğunu ileri sürmüşlerdir. Graham ve Sandmel (2011) de yaptıkları çalışmada süreç odaklı yazmanın öğrencilerin yazılarının niteliğine istatistiksel olarak anlamlı düzeyde olumlu etki ettiği, bu etkinin ise orta düzeyde $(d=0.34)$ olduğunu ortaya koymuşlardır. Başka bir çalışmada Graham vd. (2012) süreç yaklaşımının deneysel müdahale olarak kullanıldığı çalışmaların etki büyüklüğünü $d=0.40$ olarak hesaplamış olsalar da bu değerin, yaptıkları ara değişken analizinde istatistiksel olarak anlamlı olmadığı sonucuna varmışlardır.

Bunun yanında literatürde bu çalışmanın sonuçlarıyla örtüşmeyen meta analiz çalışmaları da yer almaktadır (Graham ve Sandmel, 2011; Koster vd., 2015). Bu çalışmalardan birini gerçekleştiren Graham ve Sandmel (2011) süreç odaklı yazmanın öğrenme güçlüğü çeken risk altındaki öğrencilerin yazma niteliklerinin geliştirilmesinde ve yazmaya yönelik motivasyonlarının arttırımasında anlamlı düzeyde etkili olmadığını ileri sürmüşlerdir. Bunun yanında Koster vd. (2015) yaptıkları çalışmada genel olarak planlama, yazma ve gözden geçirerek düzeltme aşamalarının uygulandığı ve sürece dayalı yazma kapsamında değerlendirilebilecek üç çalışmanın genel etki büyüklüğünü $g=-0.25$ değeriyle negatif olarak belirleyerek sürece dayalı yazma müdahalesinin öğrencilerin yazma başarısını arttırmadığı sonucuna varmışlardır. Bu durum, meta analize dâhil edilen çalışma sayısının oldukça sınırlı olmasından dolayı sonuçların sistematik farklılıkları ortaya çıkarılabilme noktasında yetersiz kalması, üç çalışmadan ikisinde süreç yaklaşımının kontrol edilen değişken olması ve deney grubunda deneysel işlem olarak daha etkili bir yaklaşımın uygulanması gibi nedenlere bağlanmıştır. Araştırmacılar çalışma sonucunda süreç yaklaşımının daha deneyimli yazarlara yapılan yazma öğretiminde daha etkili olduğunu, başlangıç düzeyindeki yazarlar için ise daha az uygun olduğunu belirtmişlerdir. Genel olarak bakıldığında farklı meta analizlerden elde edilen bulguların büyük çoğunluğunun birbiriyle ve bu çalışma sonuçlarıyla örtüştüğü görülmektedir. Ancak aynı konuda ve benzer amaçlarla yapılan meta analiz çalışmalarından farklı olarak bu çalışmada süreç odaklı yazma yaklaşımlarının öğrencilerin yazma başarı düzeyleri üzerinde küçük ya da orta değil geniş düzeyde etkili olduğu sonucuna varılmıştır.

2) Öğrencilerin yazma başarı düzeyleri, öğrenim gördükleri öğretim düzeylerine göre anlamlı düzeyde farklılaşmakta mıdır?

Öğretim düzeyi, herhangi bir deneysel işlemin sonucunun farklılaşmasına neden olan yordayıcı bir değişken olabilmektedir. Bu değişkenin, yazma başarısını yordayan anlamlı bir değişken olup olmadığının bilinmesinin, gerçekleştirilmesi düşünülen uygulamaların hangi öğretim kademelerinde yoğunlaştırılması gerektiğine yönelik önemli bir veri kaynağı olabileceği düşünülmektedir.Gerçekleştirilen süreç odaklı 
yazma uygulamalarının farklı öğretim düzeylerinde öğrenim gören öğrencilerin yazma başarılarını ne düzeyde etkilediği ve bu etkinin anlamlı olup olmadığına ilişkin bulgular Tablo 7'de yer almaktadır:

Tablo 7.

Öğretim Düzeylerine göre Çalışmaların Etki Büyüklüklerine ilişskin Bulgular

\begin{tabular}{|c|c|c|c|c|c|c|c|}
\hline \multicolumn{3}{|l|}{ Model } & \multicolumn{2}{|c|}{$\begin{array}{l}\text { \%95 Güven Aralığı } \\
\left(\% 95_{c ı}\right)\end{array}$} & \multirow[t]{2}{*}{$\begin{array}{l}\text { Serbestlik } \\
\text { Derecesi }(d f)\end{array}$} & \multicolumn{2}{|c|}{ Heterojenlik Testi } \\
\hline $\begin{array}{l}\text { Rastgele Etkiler } \\
\text { Modeli }\end{array}$ & $N$ & Hedge $g$ & Alt Sınır & Üst Sınır & & $Q$ Değeri & pDeğeri \\
\hline ilkokul & 3 & 0.626 & 0.298 & 0.954 & \multirow{4}{*}{2} & & \\
\hline Ortaokul & 4 & 0.991 & 0.715 & 1.267 & & & \\
\hline Üniversite & 14 & 1.539 & 1.206 & 1.872 & & & \\
\hline Ara toplam & & & & & & 14.892 & $0.001^{*}$ \\
\hline
\end{tabular}

Tablo 7 incelendiğinde süreç odaklı yazma modeli uygulamalarının ilkokul, ortaokul ve üniversite olmak üzere üç öğretim kademesinde yapıldığı görülmektedir. Bunlardan üniversite, 14 çalışmayla en fazla deneysel uygulamanın yapıldığı öğretim kademesi olurken bunu 4 çalışmayla ortaokul ve 3 çalışmayla ilkokul öğretim kademeleri izlemektedir. Elde edilen etki büyüklük değerlerine bakıldığında, tüm öğretim kademelerindeki etkinin pozitif yönde olduğu görülmektedir. Bunun yanında, gerçekleştirilen uygulamaların öğrencilerin yazma başarıları üzerindeki etkisi üniversite düzeyinde $g=1$. 539; ortaokul düzeyinde $g=0.991$ ve ilkokul düzeyinde $g=0.626$ olarak belirlenmiştir. Bu değerler süreç odaklı yazma uygulamalarının üniversite ve ortaokul düzeyinde öğrenim gören öğrencilerin yazma başarılarını geniş düzeyde, ilkokul öğrencilerinin yazma başarılarını ise orta düzeyde etkilediğini ortaya koymaktadır. Ayrıca tablodaki $Q_{B}=14.892$ değerinin $\chi 2$ tablosunda $\% 95$ anlamlılık düzeyinde 2 serbestlik derecesiyle belirlenen 5.991 kritik değerinin üzerinde olması; etki büyüklüklerinin ilkokul, ortaokul ve üniversite düzeylerine göre anlamlı düzeyde farklılaştığını göstermektedir.

Bu sonuç çeşitli meta analiz çalışmalarında elde edilen sonuçlarla örtüşmemektedir (Hillocks, 1986; Graham ve Perin, 2007; Graham ve Sandmel, 2011). Bu çalışmalardan birinde Hillocks (1986) etki büyüklük değerlerinin sınıf düzeylerine göre anlamlı düzeyde farklılaştığını belirlemiş ancak bu çalışmanın aksine söz konusu değerlerin ilkokul düzeyinden üniversite düzeyine gidildikçe anlamlı düzeyde düştüğünü ortaya koymuştur. Öte yandan Graham ve Perin (2007) 4-6 ve 7-12; Graham ve Sandmel (2011) 1-6 ve 7-12 olarak ikişer kategori hâlinde inceledikleri öğretim kademeleri arasında etki düzeyleri açısından anlamlı bir farklılık bulamamışlardır.

\section{3) Öğrencilerin yazma başarı düzeyleri, uygulamada kullanılan süreç odaklı yazma modellerine göre anlamlı düzeyde farklılaşmakta mıdır?}

Süreç odaklı yazma yaklaşımlarına hız veren anlayış temelde aynı olsa da uygulama aşamaları, gerçekleştirilen etkinlikler ve süreçte öngörülen rollerle ilgili bölümlerde birtakım farklılıklar bulunmaktadır. Bu farklııklar 4+1, 6+1 ve Yaratıcı Yazma gibi modellerin ortaya çıkmasını sağlamıştır. Bu modellerin yazma başarısı üzerindeki etkilerinin karşılaştırılması ve model seçiminin, elde edilen genel etki büyüklükleriniyordayan anlamlı bir değişken olup olmadığının belirlenmesi amacıyla yapılan analize ilişkin bulgular Tablo 8' de verilmektedir: 
Tablo 8.

Yazma Modellerine göre Çalışmaların Etki Büyüklüklerine Ilişskin Bulgular

\begin{tabular}{|c|c|c|c|c|c|c|c|}
\hline \multicolumn{3}{|l|}{ Model } & \multicolumn{2}{|c|}{$\begin{array}{l}\text { \%95 Güven Aralığı } \\
\left(\% 95_{c ı}\right)\end{array}$} & \multirow[t]{2}{*}{$\begin{array}{l}\text { Serbestlik } \\
\text { derecesi }(d f)\end{array}$} & \multicolumn{2}{|c|}{ Heterojenlik testi } \\
\hline $\begin{array}{l}\text { Rastgele Etkiler } \\
\text { Modeli }\end{array}$ & $N$ & Hedge $g$ & Alt Sınır & Üst Sınır & & $Q$ değeri & $\begin{array}{l}p \\
\text { değeri }\end{array}$ \\
\hline $4+1$ & 3 & 1.224 & 0.326 & 2.122 & \multirow{4}{*}{3} & & \\
\hline $6+1$ & 3 & 1.397 & 1.035 & 1.759 & & & \\
\hline SOY Genel* & 8 & 1.271 & 0.819 & 1.723 & & & \\
\hline Yaratıcı yazma & 7 & 1.354 & 0.919 & 1.789 & & & \\
\hline Ara toplam & & & & & & 0.252 & 0.969 \\
\hline
\end{tabular}

**SOY Genel: Özel bir model olarak belirtilmeyen, süreç odaklı yazma modeli başı̆ı̆ını taşıyan ya da içerik itibarıyla süreç odaklı yazma modellerinin aşamalarını içeren modeller

Tablo 8 incelendiğinde en fazla uygulamanın sekiz çalışmayla süreç odaklı yazma modellerinden SOY Genel (özel bir model olarak belirtilmeyen, süreç odaklı yazma modeli başlığını taşıyan ya da içerik itibarıyla süreç odaklı yazma modellerinin aşamalarını içeren modeller) modelinde yapıldığı, bunu yedi çalışmayla yaratıcı yazma ve üçer çalışmayla 4+1 ile 6+1 yazma modellerinin izlediği görülmektedir. Tabloda etki büyüklüklerinin $6+1$ modelinde $g=1.397$; yaratıcı yazma modelinde $g=1.354$; SOY Genel'de $g=1.271$ ve $4+1$ modelinde $g=1.224$ değerleriyle pozitif yönde ve birbirine oldukça yakın olduğu ortaya konulmaktadır. Dört model de öğrencilerin yazma başarıları üzerinde geniş düzeyde bir etkiye sahiptir. Tabloda yer alan $Q_{B}=0.252$ değerinin $\chi 2$ tablosunda \%95 anlamlılık düzeyinde 3 serbestlik derecesiyle belirlenen 7.815 kritik değerinin altında olması etki büyüklüklerinin yazma modellerine göre anlamlı düzeyde farklılaşmadığını ortaya koymaktadır.

4) Öğrencilerin yazma başarı düzeyleri, uygulama süresine (saat) göre anlamlı düzeyde farklılaşmakta mıdır?

Süreç odaklı yazma yaklaşımlarının kullanıldığı deneysel çalışmalarda öngörülen uygulama süreleri farklılık göstermektedir. Uygulama süresinin, etki büyüklük değerlerini farklılaştırıc bir etkisinin olup olmadığını ortaya koymak amacıyla yapılan ara değişken analizine yönelik bulgular Tablo 9'da verilmektedir:

Tablo 9.

Uygulama Süresine (saat) göre Çalışmaların Etki Büyüklüklerine Ilişkin Bulgular

\begin{tabular}{|c|c|c|c|c|c|c|c|}
\hline \multicolumn{3}{|l|}{ Model } & \multicolumn{2}{|c|}{$\begin{array}{l}\text { \%95 Güven Aralığı } \\
\left(\% 95_{c ı}\right)\end{array}$} & \multirow[t]{2}{*}{$\begin{array}{l}\text { Serbestlik } \\
\text { derecesi }(d f)\end{array}$} & \multicolumn{2}{|c|}{ Heterojenlik testi } \\
\hline $\begin{array}{l}\text { Rastgele Etkiler } \\
\text { Modeli }\end{array}$ & $N$ & Hedge $g$ & Alt Sınır & Üst Sınır & & $Q$ değeri & $\begin{array}{l}p \\
\text { değeri }\end{array}$ \\
\hline $14-18$ & 2 & 1.461 & 0.798 & 2.123 & \multirow{5}{*}{4} & & \\
\hline $19-23$ & 7 & 1. 013 & 0.559 & 1.466 & & & \\
\hline $24-28$ & 8 & 1.510 & 1.039 & 1.982 & & & \\
\hline $29-33$ & 2 & 1.825 & 1.509 & 2.141 & & & \\
\hline 33 ve fazlası & 2 & 1.038 & 0.059 & 2.017 & & & \\
\hline Ara toplam & & & & & & 9.341 & 0.053 \\
\hline
\end{tabular}

Tablo 9 incelendiğinde sekiz çalışmada 24-28 saat; 7 çalışmada 19-23 saat uygulama yapıldığı görülmektedir. 14-18; 29-33 ve 33 ve üzeri saat uygulama yapılan ikişer çalışma bulunmaktadır. Etki 576 
büyüklük değerlerine bakıldığında ise en yüksek etki büyüklüğünün $g=1.825$ ile 29-33 saat uygulama yapılan çalışmalardan; en düşük değerin ise $g=1.013$ ile 19-23 saat uygulama yapılan çalışmalardan elde edildiği görülmektedir. Yine etki büyüklük değerlerine bakıldığında tüm değerlerin pozitif ve geniş düzeyde olduğu görülmektedir. Bunun yanında $\mathrm{Q}_{B}=9.341$ değerinin $\chi 2$ tablosunda \%95 anlamlılık düzeyinde 4 serbestlik derecesiyle belirlenen 9.488 kritik değerinin altında olması etki büyüklüklerinin uygulama sürelerine (saat) göre anlamlı düzeyde farklılaşmadığını göstermektedir. Bu veriler, uygulama süresinin artması ve azalması durumunun yazma başarısını anlamlı düzeyde etkilemediği şeklinde yorumlanabilir.

Bu sonuç Hillocks (1986) tarafından yapılan meta analizin sonucuyla örtüşmektedir. Hillocks (1986) meta analiz kapsamında incelediği çalışmalardaki uygulama sürelerini hafta bazında gruplandırarak ikili karşılaştırmalar yapmıştır. Bu karşılaştırmalar sonucunda 13 haftadan az ve fazla süren çalışmalardan elde edilen etki büyüklükleri arasında bir fark olmadığı gibi 17 haftadan az ve fazla süren çalışmalardaki etki büyüklükleri arasında da bir fark olmadığını ortaya koymuştur.

\section{5) Öğrencilerin yazma başarı düzeyleri, uygulamada kullanılan metin türüne (bilgilendirici, hikâye edici, serbest tür) göre anlamlı düzeyde farklılaşmakta mıdır?}

Meta analiz kapsamında incelenen çalışmalarda öğrencilerin yazma başarıları,bilgilendirici ve hikâye edici metin ile öğrencinin yazma konusunda herhangi bir türle sınırlanmadığı serbest tür olmak üzere üç tür üzerinden belirlenmeye çalışılmıştır. Bazı çalışmalarda yalnızca bilgilendirici veya hikâye edici metin çalışmaları yaptırılırken bazılarında iki türden de yararlanılmıştır. Bu metin türlerine göre etki büyüklüklerinin farklılaşma durumunu belirlemeye yönelik olarak yapılan ara değişken analizinden elde edilen bulgular Tablo 10'da verilmektedir:

Tablo 10.

Metin Türüne göre Çalışmaların Etki Büyüklüklerine Ilişkin Bulgular

$\begin{array}{llll}\text { Model } & \% 95 \text { Güven Aralığı } & \text { Serbestlik } & \text { Heterojenlik testi } \\ & \left(\% 95_{c l}\right) & \text { derecesi }(d f) & \end{array}$

\begin{tabular}{llllllll}
\hline $\begin{array}{l}\text { Rastgele Etkiler } \\
\text { Modeli }\end{array}$ & $N$ & Hedge $g$ & Alt Sınır & Üst Sınır & & Q değeri & $\begin{array}{l}p \\
\text { değeri }\end{array}$ \\
\cline { 1 - 5 } Bilgilendirici & 3 & 1.870 & 0.736 & 3.003 & & & \\
Hikâye edici & 4 & 1.521 & 1.164 & 1.877 & 2 & & \\
Serbest tür & 14 & 1.132 & 0.846 & 1.419 & & & \\
Ara toplam & & & & & & 3.754 & 0.153 \\
\hline
\end{tabular}

Tablo 10 incelendiğinde süreç odaklı yazma uygulamalarının yazma başarısına etkisinin araştırıldığı çalışmalarda genellikle serbest türün tercih edildiği $(n=14)$, hikâye edici ve bilgilendirici metinlerin ise görece daha düşük sayıda tercih edildiği (sırasıyla $n=4 ; n=3$ ) görülmektedir. Bununla birlikte süreç odaklı yazma uygulamalarının bilgilendirici metin yazma başarısı üzerindeki etkisi $g=1.870$; hikâye edici metin yazma başarısı üzerindeki etkisi $g=1.521$; serbest türde metin yazma başarısı üzerindeki etkisi ise $g=1.132$ olarak belirlenmiştir. Tüm bu değerler süreç odaklı yazma uygulamalarının her üç türdeki yazma başarısı üzerinde de geniş düzeyde etkili olduğunu ortaya koymaktadır. Etki büyüklük değeri bilgilendirici metin türünde daha fazla olsa da bu durum $\mathrm{Q}_{\mathrm{B}}=3.754$ değerinin $\chi 2$ tablosunda $\% 95$ anlamlılık düzeyinde 2 serbestlik derecesiyle belirlenen 5.991 kritik değerinin altında olması nedeniyle istatistiksel olarak anlamlı bulunmamıştır. Başka bir deyişle etki büyüklük değerleri süreç odaklı yazma öğretiminde kullanılan metin türüne (bilgilendirici, hikâye edici, serbest tür) göre anlamlı şekilde farklılaşmamaktadır.

Bu sonuç Graham ve Perin (2007) ve Graham ve Sandmel (2011) tarafından yapılan meta analiz çalışmalarının sonuçlarıyla benzerlik göstermektedir. Nitekim Graham ve Perin (2007) yaptıkları çalışmada elde ettikleri etki büyüklük değerlerinin, hikâye edici ve açıklayıcı (bilgilendirici) olmak üzere 
iki kategoride ele aldıkları metin türlerine göre; Graham ve Sandmel (2011) ise hikâye edici, açıklayıcı, ikna edici ve serbest tür olarak kategorize ettikleri metin türlerine göre anlamlı düzeyde farklılaşmadığını ortaya koymaktadırlar.

6) Çalışmalardan elde edilen etki büyüklük değerleri, uygulamanın raporlaştırıldığı yayımın türüne (tez, makale) göre anlamlı düzeyde farklılaşmakta mıdır?

Tez ve makale bilimsel süreç olarak benzerlik gösterse de uygulama, değerlendirme süresi,şekil ve kapsam gibi yönlerle birbirinden ayrılabilir. Bunun, yapılan uygulama sonrasında elde edilen etki büyüklük değerlerinin farklılaşmasına neden olan bir durum olup olmadığının belirlenmesi amacıyla ara değişken analizi yapılmış ve elde edilen bulgular Tablo 11'de verilmiştir:

Tablo 11.

Yayım Türüne göre Çalışmaların Etki Büyüklüklerine Iliş̧in Bulgular

\begin{tabular}{|c|c|c|c|c|c|c|c|}
\hline \multirow{2}{*}{$\begin{array}{l}\text { Model } \\
\text { Rastgele Etkiler } \\
\text { Modeli }\end{array}$} & \multirow[b]{2}{*}{$N$} & \multirow[b]{2}{*}{ Hedge $g$} & \multicolumn{2}{|c|}{$\begin{array}{l}\text { \%95 Güven Aralığı } \\
\left(\% 95_{c ı}\right)\end{array}$} & \multirow[t]{2}{*}{$\begin{array}{l}\text { Serbestlik } \\
\text { derecesi }(d f)\end{array}$} & \multicolumn{2}{|c|}{ Heterojenlik testi } \\
\hline & & & Alt Sınır & Üst Sınır & & $Q$ değeri & $\begin{array}{l}p \\
\text { değeri }\end{array}$ \\
\hline Makale & 10 & 1.178 & 0.809 & 1.547 & & & \\
\hline Tez & 11 & 1.434 & 1.077 & 1.791 & & & \\
\hline Ara toplam & & & & & 1 & 0.955 & 0.328 \\
\hline
\end{tabular}

Tablo 11'e bakıldığında meta analiz kapsamında incelenen 11 tezde uygulanan deneysel işlem kapsamında elde edilen genel etki büyüklük değeri $g=1.434$ iken 10 makaleden elde edilen değer $g=1.178$ olarak hesaplanmıştır. Görüldüğü üzere her iki değer de pozitif yönde ve geniş bir etki büyüklüğüdür. Bunun yanında $Q_{B}=0.955$ değerinin $\chi 2$ tablosunda $\% 95$ anlamlılık düzeyinde 1 serbestlik derecesiyle belirlenen 3.841 kritik değerinin altında olması, elde edilen etki büyüklük değerlerinin uygulamanın rapor edildiği yayımın türüne (tez veya makale) göre anlamlı şekilde farklılaşmadığını ortaya koymaktadır. Başka bir deyişle çalışmanın makale ya da tez olarak yayımlanması etki büyüklüğünü istatistiksel olarak anlamlı düzeyde etkilememektedir.

Bu sonuç Graham ve Perin (2007) tarafından yapılan ve etki büyüklük değerlerinin yayım kaynağına göre anlamlı düzeyde farklılık göstermediği sonucuna varılan meta analiz çalışmasının sonuçlarıyla örtüşmektedir. Söz konusu çalışmada dergi dışındaki kaynaklarda (tez, kitap, rapor ve konferans sunumu) yayımlanan çalışmalardan elde edilen etki büyüklük değerleri ile bilimsel dergilerde yayımlanan makalelerde rapor edilen etki büyüklük değerleri arasında anlamlı bir farklılık olmadığı sonucuna varılmıştır.

7) Süreç odaklı yazma yaklaşımları; planlama, imla, sunum, cümle akıcılığı, fikirler, üslup, organizasyon ve kelime seçimi boyutlarında öğrencilerin yazma başarı düzeylerini ne düzeyde etkilemektedir?

Gerçekleştirilen uygulamaların, süreç odaklı yazma yaklaşımlarında önemli olan aşamaların hangilerinde ne düzeyde bir etkiye sahip olduğunun belirlenmesi amacıyla yapılan analizin sonuçları Tablo 12'de verilmiştir: 
Tablo 12.

Yazma Aşamalarına göre Çalışmaların Etki Büyüklüklerine Iliş̧in Bulgular

\begin{tabular}{|c|c|c|c|c|c|c|c|c|c|c|}
\hline & \multirow{2}{*}{$\frac{\overline{\bar{d}}}{\overline{\frac{1}{4}}}$} & \multirow{2}{*}{ 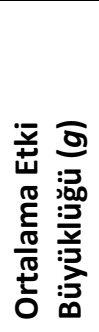 } & \multirow{2}{*}{ 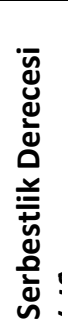 } & \multirow{2}{*}{ 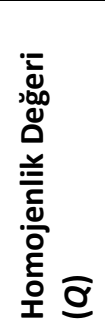 } & \multirow{2}{*}{ 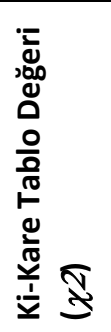 } & \multirow[t]{2}{*}{$\begin{array}{l}\text { Std. } \\
\text { Hata } \\
\text { (SE) }\end{array}$} & \multirow[t]{2}{*}{$1^{2^{*}}$} & \multicolumn{2}{|c|}{$\begin{array}{l}\text { Etki Büyüklüğü için } \\
\text { \%95 Güven Aralığı (ES, } \\
\% 95_{c ı} \text { ) }\end{array}$} & \multirow[t]{2}{*}{$\begin{array}{l}P \\
\text { değeri }\end{array}$} \\
\hline & & & & & & & & $\begin{array}{l}\text { Alt Sınır } \\
\text { (Min.) }\end{array}$ & $\begin{array}{l}\text { Üst Sınır } \\
\text { (Max) }\end{array}$ & \\
\hline Cümle akıcılığı & SEM & 1.008 & 2 & 5.110 & 5.991 & 0.157 & 60.861 & 0.701 & 1.315 & 0.078 \\
\hline Fikirler & SEM & 0.930 & 2 & 2.913 & 5.991 & 0.155 & 31.347 & 0.627 & 1.234 & 0.233 \\
\hline İmla & SEM & 1.178 & 3 & 7.723 & 7.815 & 0.136 & 61.157 & 0.912 & 1.445 & 0.052 \\
\hline Kelime seçimi & SEM & 0.838 & 2 & 1.722 & 5.991 & 0.153 & 0.000 & 0.538 & 1.138 & 0.423 \\
\hline Organizasyon & SEM & 0.876 & 2 & 2.086 & 5.991 & 0.154 & 4.117 & 0.575 & 1.178 & 0.352 \\
\hline Sunum & SEM & 1.014 & 2 & 2.559 & 5.991 & 0.156 & 21.830 & 0.707 & 1.320 & 0.278 \\
\hline Üslup & REM & 0.918 & 3 & $\begin{array}{l}31.86 \\
8\end{array}$ & 7.815 & 0.439 & 90.586 & 0.057 & 1.779 & $0.000 *$ \\
\hline Planlama & REM & 1.338 & 2 & $\begin{array}{l}66.40 \\
1 \\
\end{array}$ & 5.991 & 0.919 & 96.988 & -0.463 & 3.138 & $0.000^{*}$ \\
\hline
\end{tabular}

Tablo 12'de süreç odaklı yazma modellerinin farklı aşamalarındaki yazma başarısının rapor edildiği birincil çalışmalardan elde edilen etki büyüklük değerleri görülmektedir. Bu etki büyüklük değerlerine bakıldığında süreç odaklı yazma uygulamalarının sekiz boyutta da öğrencilerin yazma başarılarını geniş düzeyde ve pozitif anlamda etkilediği görülmektedir. İncelenen 21 çalışmanın üçünde süreç odaklı yazma uygulamalarının öğrencilerin yazılarını planlama başarılarını etkileme durumları rapor edilmiştir. Bu üç çalışmanın dâhil edildiği meta analiz kapsamında ortalama etki büyüklük değeri $Q_{B}=66.401$ değerinin $\chi 2$ tablosunda \%95 anlamlılık düzeyinde 2 serbestlik derecesiyle belirlenen 5.991 kritik değerinin oldukça üzerinde olduğundan ve $p<.05$ şartı sağlandığından çalışmalar arasında heterojenlik olduğu belirlenmiş ve sonuçlar rastgele etkiler modeline göre yorumlanmıştır. Rastgele etkiler modeline göre yapılan hesaplamada Hedge $g=1.338$ olarak belirlenmiştir. Bu değer, süreç odaklı yazma uygulamalarının yazma başarısını en geniş düzeyde etkilediği boyutun "planlama" boyutu olduğunu ortaya koymaktadır.

Bunun yanında, incelenen 21 çalışmanın dördünde süreç odaklı yazma uygulamalarının öğrencilerin yazılarındaki imla başarılarını etkileme durumları rapor edilmiştir. $\mathrm{Q}_{B}=7.723$ değerinin $\chi 2$ tablosunda \%95 anlamlılık düzeyinde 3 serbestlik derecesiyle belirlenen 7.815 kritik değerinin altında ve $p<.05$ olması sonuçların sabit etkiler modeline göre yorumlanması gerekliliğini beraberinde getirmiştir. Sabit etkiler modeline göre yapılan hesaplamada elde edilen Hedge $g=1.178$ değeri süreç odaklı yazma uygulamalarının yazma başarısını "imla" boyutunda geniş düzeyde etkilediğini ortaya koymaktadır. Tablo 12 'de süreç odaklı yazma uygulamalarının öğrencilerin yazılarındaki sunum başarılarını etkileme durumları da görülmektedir. Tabloda görülen $Q_{B}=2.559$ değeri $\chi 2$ tablosunda $\% 95$ anlamlılık düzeyinde 2 serbestlik derecesiyle belirlenen 5.991 kritik değerinin altında ve $p<.05$ olduğundan sonuçlar sabit etkiler modeline göre yorumlanmıştır. Yapılan hesaplamada elde edilen Hedge $g=1.014$ değeri süreç odaklı yazma uygulamalarının yazma başarısını "sunum" boyutunda da geniş düzeyde etkilediğini ortaya koymaktadır. Bunun yanında 21 çalışmanın üçünde süreç odaklı yazma uygulamalarının öğrencilerin kompozisyonlarındaki cümlelerin akıcılığını etkileme durumları araştırılmıştır. Tabloda görüldüğü üzere $\mathrm{Q}_{B}=7.723$ değeri $\chi 2$ tablosunda \%95 anlamlılık düzeyinde 2 serbestlik derecesiyle belirlenen 5.991 kritik değerinin altında olduğundan sonuçlar sabit etkiler modeline göre yorumlanmıştır. Sabit etkiler modeline göre dayalı olarak yapılan hesaplamada etki büyüklük değeri Hedge $g=1.008$ olarak belirlenmiştir. Bu değer süreç odaklı yazma uygulamalarının yazma başarısını "cümle akııılığı" boyutunda da geniş düzeyde etkilediğini göstermektedir. "Fikirler" boyutuna bakıldığında da $Q_{B}=2.913$ değerinin $\chi 2$ 
tablosunda \%95 anlamlılık düzeyinde 2 serbestlik derecesiyle belirlenen 5.991 kritik değerinin yine altında olduğu görülmektedir. Bu nedenle sabit etkiler modeline göre yapılan hesaplamada Hedge $g=0.930$ olarak belirlenmiştir. Bu değer süreç odaklı yazma uygulamalarının yazma başarısını "sunum" boyutunda da geniş düzeyde etkilediğini göstermektedir. Çalışmaların dördünde ise söz konusu uygulamaların üslup boyutundaki etkisi araştırılmıştır. Bu çalışmalarda yer alan istatistiki verilere dayalı olarak yapılan hesaplama sonucunda elde edilen etki büyüklük değerleri, $Q_{B}=31.868$ değerinin $\chi 2$ tablosunda \%95 anlamlılık düzeyinde 3 serbestlik derecesiyle belirlenen 7.815 kritik değerinin üzerinde olması nedeniyle rastgele etkiler modeline göre yorumlanmıştır. Rastgele etkiler modeline göre yapılan yorumlamada elde edilen Hedge $g=0.918$ değeri süreç odaklı yazma uygulamalarının yazma başarısını "üslup" boyutunda geniş düzeyde etkilediğini ortaya koymaktadır.

Tabloda ayrıca süreç odaklı yazma uygulamalarının öğrencilerin yazılarındaki organizasyon başarılarını etkileme durumları görülmektedir. Tabloda yer alan $Q_{B}=2.086$ değeri $\chi 2$ tablosunda \%95 anlamlılık düzeyinde 2 serbestlik derecesiyle belirlenen 5.991 kritik değerinin altında ve p<.05 olduğundan sonuçlar sabit etkiler modeline göre yorumlanmıştır. Yapılan hesaplamada elde edilen Hedge $g=0.876$ değeri süreç odaklı yazma uygulamalarının yazma başarısını "organizasyon" boyutunda da geniş düzeyde etkilediğini göstermektedir.

Son olarak "kelime seçimi" boyutuna ilişkin olarak tabloda yer alan $\mathrm{Q}_{B}=1.722$ değerinin $\chi 2$ tablosunda \%95 anlamlılık düzeyinde 2 serbestlik derecesiyle belirlenen 5.991 kritik değerinin altında olduğu ve sonuçların sabit etkiler modeline göre yorumlanması gerektiği anlaşılmaktadır. Sabit etkiler modeline göre dayalı olarak yapılan hesaplamada etki büyüklük değeri Hedge $g=0.838$ olarak belirlenmiştir. Bu değer süreç odaklı yazma uygulamalarının yazma başarısını "kelime seçimi" boyutunda da geniş düzeyde etkilediğini göstermektedir.

Görüldüğü üzere süreç odaklı yazma yaklaşımlarının öğrencilerin yazma başarı düzeylerini en üst düzeyde etkilediği aşama "planlama" aşamasıdır. Yapılan araştırmalar yazılı anlatımı geliştirmede ön hazırlığın oldukça önemli olduğunu, buna rağmen öğrencilerin en çok zorlandıkları ve hata yaptıkları alanın yazılarını planlama aşaması olduğunu ortaya koymaktadır (Arıcı, 2008;Tekşan, 2001). Bu noktada süreç odaklı yazma yaklaşımlarının öğrencilerin yazma öncesi aşamada -özellikle planlama boyutundayaşadıkları zorlukların üstesinden gelebilmelerinde oldukça işlevsel ve etkili bir yaklaşım olduğunu söylemek mümkündür.

\section{Sonuç ve Öneriler}

Nitelikli bir yazma öğretiminin nasıl olması gerektiği sorusu ana dil öğretimi sahasında tartışılagelen bir konudur. Bu tartışmanın odak noktasını yazma eğitiminin amacının ürün mü yoksa süreç içerisinde geliştirilmesi beklenen zihinsel, dilsel ve sosyal beceriler mi olduğu sorusuna verilen yanıtlar oluşturmaktadır. Bilişsel ve üst bilişsel farkındalığa, öğrenen özerkliğine, motivasyona, bireysel farklılıklara, sosyal gelişime ve iş birlikli öğrenmeye önem veren 21. yüzyıl dil öğretimi uygulamalarında diğer dil becerilerinde olduğu gibi yazma becerisinin gelişiminde de sürecin en az ürün kadar önemli olduğu savunulmaktadır. Bu nedenle süreç odaklı yaklaşımlarda, yazma yeterliliğini öğrencilerin birtakım teknik bilgileri öğrenmesi ile sınırlandıran geleneksel ürün odaklı yaklaşıma karşı çıkılmaktadır. Bu doğrultuda yapılan birçok araştırmada da bu anlayışı destekleyici nitelikte bulgulara ulaşılmakta ve süreç odaklı yaklaşıma dayalı olarak gerçekleştirilen yazma öğretiminin öğrencilerin yazma başarılarını arttırdığı sonucuna varılmaktadır (Özkara, 2007; Şentürk, 2009; Karatay, 2011; Sever, 2013; Kaldırım, 2014; Yılmaz ve Aklar, 2015). Bu bağlamda araştırma, bireysel araştırmalardan elde edilen bu sonuçların sentezlenmesi ve süreç odaklı yazma yaklaşımlarının geleneksel ürün odaklı yazma yaklaşımı karşısındaki etkililiğinin belirlenmesi amacıyla gerçekleştirilmiştir. Bu amaçla gerçekleştirilen çalışma sonucunda meta analize dâhil edilen 21 çalışmanın etki büyüklüğü $g=1.303$; düzeltilmiş etki büyüklüğü ise $g=0.983$ olarak hesaplanmıştır. Öğrencilerin yazma başarı düzeyleri üzerindeki etkinin en fazla olduğu süreç odaklı yazma modeli $g=1.397$ ile 6+1 analitik yazma ve değerlendirme modeli olurken diğer bir süreç odaklı yazma modeli olan 4+1 planlı yazma ve değerlendirme modelinin etki büyüklük değeri 
$g=1.224$ olarak saptanmıştır. Bunun yanında yaratıcı yazma modelinin etki büyüklük değeri $g=1.354$; "SOY Genel" olarak kısaltılan ve özel bir model olarak belirtilmese de içerik itibarıyla süreç odaklı yazma modellerinin aşamalarının takip edildiği modellerin etki büyüklük değeri ise $g=1.271$ olarak belirlenmiştir. Bu bulgu, süreç odaklı yazma yaklaşımlarının öğrencilerin yazma başarı düzeyleri üzerinde olumlu yönde büyük bir etkisinin olduğunu ortaya koymaktadır.

Meta analizin diğer alt amaçlarına dayalı olarak gerçekleştirilen ara değişken analizinin sonucuna göre süreç odaklı yazma uygulamalarının süresinin yazma başarı düzeyi üzerinde anlamlı düzeyde etkili olmadığı belirlenmiştir. Bunun yanında elde edilen sonuçlar, etki büyüklük değerlerinin süreç odaklı yazma öğretiminde kullanılan metin türüne (bilgilendirici, hikâye edici, serbest tür) göre anlamlı şekilde farklılaşmadığını göstermektedir.Elde edilen sonuçlar çalışmanın makale ya da tez olarak yayımlanması durumunun etki büyüklüğünü istatistiksel olarak anlamlı düzeyde etkilemediğini de ortaya koymaktadır.

Araştırma sonuçları süreç odaklı yazma yaklaşımlarının farklı öğretim kademelerinde farklı düzeylerde etkili olduğunu ve öğretim kademeleri arasındaki bu farklılı̆ın anlamlı olduğunu ortaya koymaktadır. Buna göre süreç odaklı yazma yaklaşımları üniversite ve ortaokul düzeyinde öğrenim gören öğrencilerin yazma başarılarını geniş düzeyde etkilerken ilkokul öğrencilerinin yazma başarılarını orta düzeyde etkilemektedir.

Çalışma kapsamında süreç odaklı yazma uygulamalarının yazmanın farkıı boyutlarına olan etkisi de araştırılmıştır. Araştırma sonucunda süreç odaklı yazma uygulamalarının meta analize dâhil edilen sekiz boyutta da öğrencilerin yazma başarılarını geniş düzeyde ve olumlu yönde etkilediği belirlenmiştir. Bu sekiz boyuttaki etki büyüklükleri ise sırasıyla şu şekildedir: planlama ( $g=1.338$ ); imla ( $g=1.178)$; sunum ( $g=1.014)$; cümle akıcılığı ( $g=1.008)$; fikirler $(g=0.930)$, üslup ( $g=0.918)$, organizasyon $(g=0.876)$ ve kelime seçimi $(g=0.838)$.

Süreç odaklı yazma yaklaşımı; aşamaları, içeriği ve uygulama teknikleri ile yazmanın tüm süreçlerinin önemsendiği, tutarlı ve istikrarlı bir planlamaya dayalı olarak uygulandığı takdirde istendik öğrenme çıktılarına ulaşıımasına katkı sağlayacak bir yazma yaklaşımıdır. Bu noktada süreç odaklı yazma yaklaşımlarına dayalı olarak gerçekleştirilen uygulamalarda sınıf içi ve dışındaki öğrenme öğretme etkinliklerinin öğrencilerin yazma intiyaçlarını ve yazmaya yönelik beklentilerini karşılayacak nitelikte olması önem arz etmektedir. Bunun yanında yazma becerilerinin geliştirilmesi için öğretim zamanının iyi planlanması ve süreç boyunca geliştirilmesi amaçlanan alt beceri ve yeterliliklerin net bir şekilde tanımlanması gerekmektedir. Özellikle de tanımlama sürecinde yazma amaçlarına ve hedef kitlenin özelliklerine uygun olarak geliştirilmiş ölçme araçlarının kullanılması önemlidir. Öğrenme öğretme sürecindeki uygulamaların etkililiğinin ve işlevselliğinin değerlendirilmesi, öğrencilerin yazma beceri düzeylerinin gelişiminin izlenmesi ve değerlendirmenin de süreç odaklı yapılması üzerinde titizlikle durulması gereken hususlar olmalıdır. Öğrencilerin de sürecin içinde yer alacağı bir çoklu değerlendirme anlayışı benimsenmelidir.

Meta-analizlerin amaçlarından biri, ihtiyaç duyulan ya da eksikliği ortaya konulan alanları belirleyerek sonraki araştırmalara kaynaklık etmektir (Oswald ve Plonsky, 2010). Bu araştırmanın da alanda yapılacak olan çalışmalara pedagojik ve kuramsal bir alt yapı sağlayacağı düşünülmektedir. Yapılacak çalışmalarda yazma üzerinde yordayıcı etkisi olabilecek yaş, eğitim düzeyi, cinsiyet, kitap okuma sıklı̆ı̆, akademik başarı gibi değişkenlerin genel etkisi incelenebilir. Bunun yanında Türkçe dersi öğretim programlarında da süreç temelli yazma aşamalarına göre oluşturulmuş etkinliklere ve bu etkinliklerin uygulama adımlarına daha ayrıntılı olarak yer verilmesi, deneysel çalışmalarda belli bir standardın oluşturulmasını ve sonuçların daha güvenilir bir şekilde değerlendirebilmesini kolaylaştıracaktır.

\section{Sınırlılıklar}

Özellikle yurt içi literatürde çeşitli yazma yöntem ve tekniklerinin öğrencilerin yazma başarılarını etkileme düzeylerini belirlemeye yönelik deneysel araştırmaların sınırlı olması, yapılacak meta analiz 
çalışmalarının genellenebilirliğini tehdit eden bir unsurdur. Bu açıdan bakıldığında daha geniş kapsamlı meta analiz çalışmalarının gerçekleştirilebilmesi için yöntemsel ve niteliksel olarak kabul edilebilir düzeyde olan ve istatistiki açıdan yorumlanabilecek bulguların elde edildiği çalışmalara ihtiyaç duyulmaktadır. Meta analiz kapsamında incelenen çalışmalar genel olarak incelendiğinde çalışmaların büyük çoğunluğundason testin sonrasında kalıcılık testinin yapılmadığı görülmektedir. Kalıcılık testinin yapılmadığı deneysel çalışmalardan elde edilen sonuçlar, deneysel müdahalenin gerçek etkililiği hakkında yanıltıcı sonuçlar verebilmektedir. Özellikle yazma becerisinin gelişiminin süreklilik arz eden yapısı ve öğrenilen bilginin beceriye dönüşmesinin kısa vadedeki zorluğu düşünüldüğünde bu becerinin kalıcılığının da test edilmesi gerekliliği ortaya çıkmaktadır. Bu durum araştırma sonuçlarının, yayın yanlılığına olan direncini düşürebilir. Bunun yanında kategorik değişkenlerin sayısal olarak dengeli bir dağılıma sahip olmaması (örneğin üniversite düzeyinde daha fazla çalışma yapılırkenilkokul ve ortaokul düzeylerinde yapılan çalışmaların az olması) yapılan ara değişken analizinin sonuçlarını etkilemiş ve geçici sonuçlar ortaya koymuş olabilir. Bunun yanında incelenen deneysel çalışmalardaki istatistiksel verilerin süreç odaklı yazmanın aşamalarına göre ayrı ayrı rapor edilmemişti. Bu nedenle çalışmada süreç odaklı yazma aşamalarına göre bir ara değişken analizi yapılamamış ve yalnızca çalışmaların genel etki büyüklüğü değerlerine yer verilmiştir. Bu da araştırmanın diğer bir sınırlılığını oluşturmaktadır. 


\section{References}

References marked with an asterisk (*) indicate studies included in the meta-analysis.

*Ak, E. (2011). The effect of creative writing techniques on the written expression skills of $5^{\text {th }}$ grade students in Turkish lessons. Unpublished Master's Thesis. Dokuz EylulUniversitylnstitute of Educational Sciences, İzmir.

Arıcı, A. F. (2008). University students' written expression mistakes. Uludağ University Journal of Faculty of Education, 21(2), 209-220.

Badger, R.,\& White, G. (2000). A process genre approach to teaching writing. ELT Journal, 54(2), 153160. doi: $10.1093 /$ elt/54.2.153

Bangert-Drowns, R. L., Hurley, M. M., \& Wilkinson, B. (2004). The effects of school-based writing-to-learn interventions on academic achievement: A meta-analysis. Review of Educational Research, 74(1), 2958.doi: 10.3102/00346543074001029

*Bayat, N. (2014). The effect of the process writing approach on writing success and anxiety. Educational Sciences: Theory \& Practice, 14(3), 1123-1141.doi: 10.12738/estp.2014.3.1720

Begg, C. B.,\& Mazumdar, M. (1994). Operating characteristics of a rank correlation testfor publication bias. Biometrics, 50. 1088-1101.doi: 10.2307/2533446

*Beydemir, A. (2010). The effect of creative writing approach on writing attitude, creative writing and writing achievement in Turkish classes at fifth grade in a primary. Unpublished Master'sThesis, Pamukkale University Institute of Social Sciences, Denizli.

Borenstein, M., Hedges, L. V., Higgins, J. P., \& Rothstein, H. R. (2013). Introduction to meta-analysis (S. Dinçer, Trans.). Ankara: Anı.

Boscolo, P. (2009). Writing in primary school. In Charles Bazerman (Ed.), Handbook of research on writing: history, society, school, individual, text(pp. 359-380). NY: LEA, Taylor \& Francis.

Cohen, J. (1988). Statistical power analysis for the behavioral sciences $\left(2^{\text {nd }}\right.$ ed.). Hillsdale, NJ: Lawrence Earlbaum Associates.

Coşkun, E., Balcı, A., \& Özçakmak, H. (2013). Trends in writing education: An analysis of postgraduate theses written in Turkey. Procedia-Social and Behavioral Sciences, 93. 1526- 1530. doi:10.1016/j.sbspro.2013.10.076

Culham, R. (2003). 6+1 Traits of Writing: The complete guide grades 3 and up. New York: Scholastic.

Cumming, G. (2012). Understanding the new statistics: effect sizes, confidence intervals, and metaanalysis. NY: Routledge.

De Glopper, C. M., \& van Kruiningen, J. F., \& Hemmen, N. (2014). Context in Writing Process Research: An exploratory analysis of context characteristics in writing process research in educational and workplace settings. Poster session presented at COWR (Conference on Writing Research) of the EARLI (European Associtation for Research on Learning and Instruction), 27-29 August 2014. Amsterdam, Netherlands. doi: 10.3726/978-3-653-02367-1

DeJarnette, N. K. (2008). Effect of the $6+1$ trait writing model on student writing achievement.Doctoral Dissertation, Liberty University, Virgina.

Dinçer, S. (2014). Eğitim bilimlerinde uygulamalı meta-analiz. Ankara: Pegem Akademi.

*Doğan, Y.,\& Müldür, M. (2014). Effect of writing training provided for $7^{\text {th }}$ grade students on the storywriting skills of students. Mersin University Journal of the Faculty of Education, 10(1), 49-65.

Dukpa, L. (1997). Using the writing process model to teach writing at the junior high school level in Durk Yul: An action research. Master's Thesis. University of New Brunswick, Canada.

Elbir, B.,\& Yıldız, H. (2012). The evaluation of graduate studies on teaching writing in the primary school. Academic Sight International Refeered Online Journal of Social Sciences, 30, 1-11.

Ellis, P. D. (2010). The essential guide to effect sizes: statistical power, meta-analysis, and the interpretation of research results. London, UK: CUP. 
*Erdoğan, Ö. (2012). The effects of process based creative writing activities on students' writing expression and attitude towards writing. Unpublished Doctoral Thesis, Hacettepe University Graduate School of Social Sciences, Ankara.

*Erdoğan, Ö.,\& Yangın, B. (2014). The effect of process based creative writing activities on students' writing expression and attitude towards writing. Journal of Faculty of Education, 14(1).

Fragkos K., Tsagris M., \& Frangos C. (2014). Publication bias in meta-analysis: Confidence intervals for Rosenthal's Fail-Safe Number. International Scholarly Research Notices, 1-17. doi: $10.1155 / 2014 / 825383$

Gillespie, A.,\& Graham, S. (2014). A meta-analysis of writing interventions for students with learning disabilities, 80(4), 454-473. doi: 10.1177/0014402914527238

Glass, G. (1976). Primary, secondary, and meta-analysis of research. Educational Researcher, 5(10), 3-8.

Graham, S., McKeown, D., Kiuhara, S., \& Harris, K. (2012). A meta-analysis of writing instruction for students in the elementary grades. Journal of Educational Psychology, 104(3), 879-896. doi: $10.1037 / \mathrm{a} 0029185$

Graham, S.,\& Perin, D. (2007). A meta-analysis of writing instruction for adolescent students. Journal of Educational Psychology, 99(3), 445-476. doi: 10.1037/0022- 0663.99.3.445

Graham, S. \& Sandmel, K. (2011) The Process Writing Approach: A meta-analysis, The Journal of Educational Research, 104(6), 396-407. doi: 10.1080/00220671.2010.488703

Guy, A. E., Jr. (2009). Process writing: Reflection and the arts of writing and teaching. In S. Vilardi \& M. Chang (Eds.), Writing based teaching: Essential practices and enduring questions (pp. 53-70). Albany: State University of New York Press.

Gürbüz, S.,\& Şahin, F. (2014). Sosyal bilimlerde araştırma yöntemleri: Felsefe, yöntem, analiz. Ankara: Seçkin.

Heene, M. (2010). A brief history of the Fail Safe Number in applied research. University of Graz, Austria.

Higgins, J. P. T.,\& Thompson, S. G. (2002). Quantifying heterogeneity in a meta analysis. Statistics in Medicine, 21. 1539-1558. doi: 10.1002/sim.1186

Hillocks, G. J. (1984).What works in teaching composition: A meta-analysis of experimental treatment studies. American Journal of Education, 93(1), 133-170.

Hillocks, G. J. (1986). Research on written composition: New directions for teaching. Urbana, IL: National Council of Teachers of English.

Huedo-Medina, T. B., Sánchez-Meca, J., Marín-Martínez, F., \& Botella, J. (2006). Assessing heterogeneity in meta-analysis: Q statistic or $\mathrm{I}^{2}$ index? Psychological Methods, 11(2), doi: 193-206.10.1037/1082989X.11.2.193

*izdeş, M. (2011). The effects of writing education to $7^{\text {th }}$ grade students on their story writing skills. Unpublished Master's Thesis, Gazi University Institute of Educational Sciences, Ankara.

*Kaldırım, A. (2014). The impact of 6+1 Analytic Writing and Evaluation Model on sixth grade middle school students' written expression skills. Unpublished Master's Thesis, Dumlupınar University Institute of Educatioanl Sciences, Kütahya.

*Kapar Kuvanç, E. B. (2008). The effect of creative writing techniques to students' attitudes to Turkish course and their successes in Turkish courses. Master's Thesis, Dokuz Eylul Universitylnstitute of Educational Sciences, İzmir.

*Karatay, H. (2011). The effect of 4+1 planned writing and evaluation model to develop the attitudes of preservice teachers as to written expression and their writing skills. Turkish Studies, 6(3), 1029-1047. doi: 10.7827/TurkishStudies.2622

Karatay, H. (2015). Süreç temelli yazma modelleri: 4+1 planlı yazma ve değerlendirme modeli. In Murat Özbay (Ed.), Yazma eğitimi (p. 21-48). Ankara: Pegem Akademi.

*Korkmaz, G. (2015). The effect of creative writing method on the 6th graders' perception of writing selfefficacy, attitudes towards writing and academic success of writing skill.Master's Thesis, Gaziantep University Institute of Educational Sciences, Gaziantep. 
Koster, M., Tribushinina, E., De Jong, P.F., \& Van den Bergh, B. (2015) .Teaching children to write: a meta-analysis of writing intervention research. Journal of Writing Research, 7(2), 299-324. doi: 10.17239/jowr-2015.07.02.2

Landis, J. R.,\& Koch, G. G. (1977). The measurement of observer agreement for categorical data. Biometrics, 33(1), 159-174.

Lipsey, M. W.,\& Wilson, D. B. (2000). Practical meta analysis. Thousand Oaks, CA: Sage.

MEB. (2015). ilköğretim Türkçe Dersi (1.2.3.4.5.6. 7 ve 8. sınıflar) Öğretim Programı. Ankara: Millî Eğitim Bakanlığı Yayınları.

Nunan, D. (2001). Language teaching methodology: A textbook for teachers. NJ: Prentice Hall.

Oral, G. (2008). Yine yazı yazıyoruz. Ankara: Pegem A.

Orwin, R. G.,\& Vevea, J. L. (2009). Evaluating coding decisions. In H. Cooper, L. V. Hedges \& J. C. Valentine (Eds.), The handbook of research synthesis and meta-analysis (pp. 177-203). New York: Russell Sage Foundation.

Oswald, F. L.,\& Plonsky, L. (2010). Meta-analysis in second language research: Choices and challenges. Annual Review of Applied Linguistics, 30, 85-110.

*Özdemir, B. (2014). The effect of analytical writing and assessment method on pre-service Turkish teachers' writing skills and attitudes towards writing. Unpublished Doctoral Dissertation, Gazi University Institute of Educational Sciences, Ankara.

* Özkara, Y. (2007). The effect of $6+1$ analytic writing and evaluate model on enhancing $5^{\text {th }}$ grade students' narrative writing skills.Unpublished Doctoral Dissertation, Gazi University Institute of Educational Sciences, Ankara.

*Öztürk, E. (2007). Evaluating the creative writing skills of the $5^{\text {th }}$ grades of primary education. Unpublished Doctoral Dissertation, Gazi University Institute of Educational Sciences, Ankara.

Rogers, L. A.,\& Graham, S. (2008). A meta-analysis of single subject design writing intervention research. Journal of Educational Psychology, 100(4), 879-906. doi:10.1037/0022-0663.100.4.879

Rosenthal, R. (1979). The file drawer problem and tolerance for null results. Psychological Bulletin, 86. 638-641.

Rothstein, H. R., Sutton, A. J., \& Borenstein, M. (2005). Publication bias in meta-analysis: prevention, assessment and adjustments. UK: John Wiley \& Sons.

*Seban, D. (2012). The effect of authoring cycle on third grade students' attitudes towards writing, selfperception and writing ability. Education and Sciences, 37(164), 147-158.

*Sever, E. (2013).The effect of processed writing models at the 4th level of primary school students on their writing and creative writing. Unpublished Master's Thesis, Bülent Ecevit University Institute of Social Sciences, Zonguldak.

*Sever, E.,\& Memiş, A. (2013).The effects of process-based writing models on primary school $4^{\text {th }}$ grade students' spelling-punctuation skills and writing dispositions. The Black Sea Journal of Social Sciences 5(9).

Sharples, M. (1998). How we write: Writing as creative design. London: Routledge.

Sim, J.,\& Wright, C. C. (2005). The Kappa statistic in reliability studies: Use, interpretation, and sample size requirements. Physical Therapy, 85(3), 257-268.

Sutton, A. J. (2009). Publication bias. In H. Cooper, L. V. Hedges \& J. C. Valentine (Eds.), The handbook of research synthesis and meta-analysis (pp. 435-452) New York: Russell Sage Foundation.

*Şentürk, N. (2009). The effect of planned writing and evaluate model on enhancing $8^{\text {th }}$ grade students' expository writing skills. Unpublished Master's Thesis, Abant İzet Baysal University Institute of Social Sciences, Bolu.

Tabachnick, B. G.,\& Fidell, L. S. (2015). Using multivariate statistics (Mustafa Baloğlu, Trans.) Ankara: Nobel.

Tekşan, K. (2001). The effect of preliminary preparation on writing skills development Doctoral Dissertation, Çanakkale Onsekiz Mart University Institute of Social Sciences, Çanakkale.

*Temizkan, M. (2011). The effect of creative writing activities on the story writing skill. Educational Sciences: Theory \& Practice, 11(2), 919-940. 
Tok, M.,\& Potur, Ö. (2015). Trends of the academic studies in writing education area (2010 - 2014 years). Journal of Mother Tongue Education, 3(4), 1-25.

*Tonyalı, E. (2010). The effect of creative writing practice on the writing skills of $6^{\text {th }}$ grade primary school students. Master's Thesis, Abant İzzet Baysal University Institute of Social Sciences, Bolu.

Uyar, Y. (2016). Research on development of writing skills: Review Of last quarter century.Turkish Studies, 11(3), 2273-2294. doi: 10.7827/TurkishStudies.9479

*Ülper, H.,\& Uzun, L. (2009).The effect of the writing programme prepared in accordance with cognitive process model on student success. Elementary Education Online, 8(3), 651-665.

Üstün, U.,\& Eryılmaz, A. (2014). A research methodology to conduct effective research syntheses: MetaAnalysis. Education and Sciences, 39(174), 1-32. doi: 10.15390/EB.2014.3379

Wilson, D. B. (2009). Systematic coding. In H. Cooper, L. V. Hedges, \& J. C. Valentine (Eds.), The handbook of research synthesis and meta-analysis (2nd ed., pp. 159-176). New York: Russell Sage Foundation.

*Yılmaz, M.,\& Aklar, S. (2015). The effect of planned writing and evaluation model on enhancing 5th grade students' composition writing skills.Bartın University The Journal of Faculty of Education Special Issue on XIV. International Participation Symposium of Primary School Teacher Education (2123 May, 2015), 223-23.

\section{Appendices}

Appendix 1. The distribution of upper and lower limit values for effect sizes in $95 \%$ confidence interval according to random effect size model for the difference between winsorized mean and standardized mean, Hedge's g effect size index, standard error, variance and $p$ values belonging to the experimental studies which examines the effect of process-based writing models on students' writing success

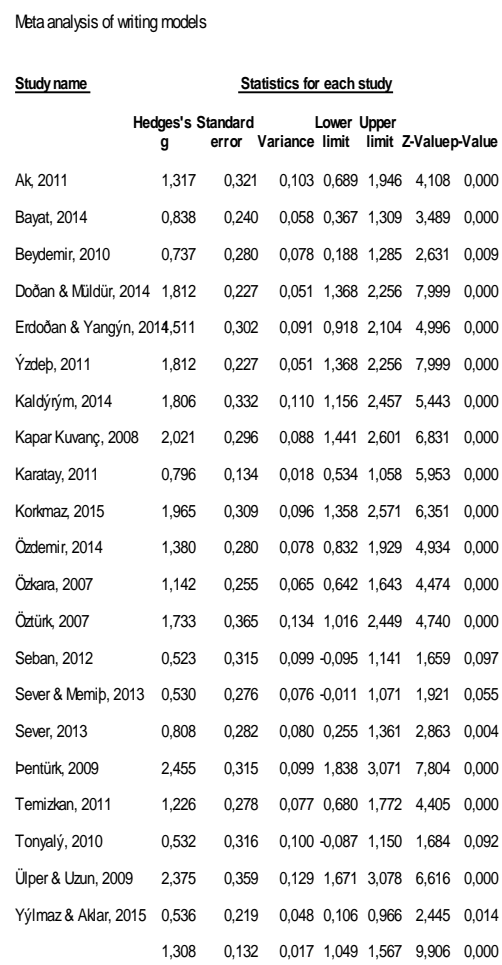

$\underline{\text { Studyname }}$

Statistics for each study Hedges's Standard Lower Upper
$\mathrm{g}$ error Variance limit limit Z-Valuep-Value

Ak, $2011 \quad \begin{array}{llllllll}1,317 & 0,321 & 0,103 & 0,689 & 1,946 & 4,108 & 0,000\end{array}$

$\begin{array}{lllllllll}\text { Bayat, } 2014 & 0,838 & 0,240 & 0,058 & 0,367 & 1,309 & 3,489 & 0,000\end{array}$

$\begin{array}{llllllll}\text { Beydemir, } 2010 & 0,737 & 0,280 & 0,078 & 0,188 & 1,285 & 2,631 & 0,009\end{array}$

$\begin{array}{lllllllll}\text { Doőan \& Mildür, } 2014 & 1,812 & 0,227 & 0,051 & 1,368 & 2,256 & 7,999 & 0,000\end{array}$

$\begin{array}{llllllll}\text { Erdoōan \& Yangýn, 2014,511 } & 0,302 & 0,091 & 0,918 & 2,104 & 4,996 & 0,000\end{array}$

$\begin{array}{llllllll}\dot{y} \text { Ýdep, } 2011 & 1,812 & 0,227 & 0,051 & 1,368 & 2,256 & 7,999 & 0,000\end{array}$

$\begin{array}{llllllll}\text { Kaldýrým, } 2014 & 1,806 & 0,332 & 0,110 & 1,156 & 2,457 & 5,443 & 0,000\end{array}$

$\begin{array}{lllllllllllll}\text { Kapar Kuvanç, } 2008 & 2,021 & 0,296 & 0,088 & 1,441 & 2,601 & 6,831 & 0,000\end{array}$

$\begin{array}{llllllllll}\text { Karatay, } 2011 & 0,796 & 0,134 & 0,018 & 0,534 & 1,058 & 5,953 & 0,000\end{array}$

$\begin{array}{llllllllll}\text { Korkmaz, } 2015 & 1,965 & 0,309 & 0,096 & 1,358 & 2,571 & 6,351 & 0,000\end{array}$

$\begin{array}{llllllll}\text { Özdemir, } 2014 & 1,380 & 0,280 & 0,078 & 0,832 & 1,929 & 4,934 & 0,000\end{array}$

$\begin{array}{lllllllll}\text { Özkara, } 2007 & 1,142 & 0,255 & 0,065 & 0,642 & 1,643 & 4,474 & 0,000\end{array}$

$\begin{array}{lllllllll}\text { Özürk, } 2007 & 1,733 & 0,365 & 0,134 & 1,016 & 2,449 & 4,740 & 0,000\end{array}$

$\begin{array}{lllllllll}\text { Seban, } 2012 & 0,523 & 0,315 & 0,099 & -0,095 & 1,141 & 1,659 & 0,097\end{array}$

Sever \& Memip, $2013 \quad 0,530 \quad 0,276 \quad 0,076-0,011 \quad 1,071 \quad 1,921 \quad 0,055$

$\begin{array}{lllllllll}\text { Sever, } 2013 & 0,808 & 0,282 & 0,080 & 0,255 & 1,361 & 2,863 & 0,004\end{array}$

$\begin{array}{lllllllllll}\text { Pentürk, } 2009 & 2,455 & 0,315 & 0,099 & 1,838 & 3,071 & 7,804 & 0,000\end{array}$

$\begin{array}{lllllllll}\text { Temizkan, } 2011 & 1,226 & 0,278 & 0,077 & 0,680 & 1,772 & 4,405 & 0,000\end{array}$

$\begin{array}{lllllllll}\text { Tonyalý, } 2010 & 0,532 & 0,316 & 0,100 & -0,087 & 1,150 & 1,684 & 0,092\end{array}$

$\begin{array}{lllllllll}\text { Ülper \& Uzun, } 2009 & 2,375 & 0,359 & 0,129 & 1,671 & 3,078 & 6,616 & 0,000\end{array}$

Yýlmaz \& Akar, $2015 \quad 0,536 \quad 0,219 \quad 0,048 \quad 0,106 \quad 0,966 \quad 2,445 \quad 0,014$ $\begin{array}{lllllllll}1,308 & 0,132 & 0,017 & 1,049 & 1,567 & 9,906 & 0,000\end{array}$

Hedges's g and $95 \% \mathrm{CI}$

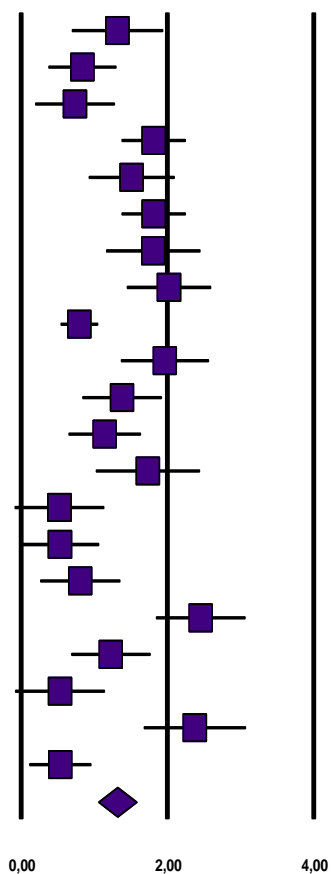

